ANA PAULA DA SILVA

\title{
AVALIAÇÃO HISTOPATOLÓGICA DO TRATAMENTO DO CARCINOMA ESPINOCELULAR CUTÂNEO EM CAMUNDONGOS USANDO TERAPIA FOTODINÂMICA MEDIADA POR AZUL DE METILENO
}

Tese apresentada ao Programa de Pós-Graduação em Biologia Celular e Tecidual do Instituto de Ciências Biomédicas da Universidade de São Paulo, para obtenção do Título de Doutor em Ciências. 
ANA PAULA DA SILVA

\section{AVALIAÇÃO HISTOPATOLÓGICA DO TRATAMENTO DO CARCINOMA ESPINOCELULAR CUTÂNEO EM CAMUNDONGOS USANDO TERAPIA FOTODINÂMICA MEDIADA POR AZUL DE METILENO}

Tese apresentada ao Programa de Pós-Graduação em Biologia Celular e Tecidual do Instituto de Ciências Biomédicas da Universidade de São Paulo, para obtenção do Título de Doutor em Ciências.

Área de Concentração: Biologia Celular e Tecidual

Orientador: Prof. Dr. José Roberto Machado Cunha da Silva

Versão corrigida. A versão original eletrônica encontra-se disponível tanto na Biblioteca do ICB quanto na Biblioteca Digital de Teses e Dissertações da USP (BDTD); 
DADOS DE CATALOGAÇÃO NA PUBLICAÇÃO (CIP)

Serviço de Biblioteca e Informação Biomédica do

Instituto de Ciências Biomédicas da Universidade de São Paulo

(c) reprodução total

Silva, Ana Paula da.

Avaliação histopatológica do tratamento do carcinoma espinocelular cutâneo em camundongos usando terapia fotodinâmica mediada por azul de metileno / Ana Paula da Silva. -- São Paulo, 2014.

Orientador: Prof. Dr. José Roberto Machado Cunha da Silva.

Tese (Doutorado) - Universidade de São Paulo. Instituto de Ciências Biomédicas. Departamento de Biologia Celular e do Desenvolvimento. Área de concentração: Biologia Celular e Tecidual. Linha de pesquisa: Terapia fotodinâmica.

Versão do título para o inglês: Histopathological evaluation of the treatment of cutaneous squamous cell carcinoma in mice using photodynamic therapy mediated by methylene blue.

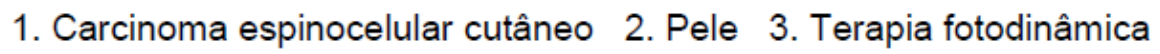
4. Azul de metileno 5. Camundongos 6. DMBA/TPA I. Silva, Prof. Dr. Jose Roberto Machado Cunha da II. Universidade de São Paulo. Instituto de Ciências Biomédicas. Programa de Pós-Graduação em Biologia Celular e Tecidual III. Título. 
Candidato(a):

Título da Tese:

Orientador(a):
Ana Paula da Silva.

Avaliação histopatológica do tratamento do carcinoma espinocelular cutâneo em camundongos usando terapia fotodinâmica mediada por azul de metileno.

Prof. Dr. José Roberto Machado Cunha da Silva.

A Comissão Julgadora dos trabalhos de Defesa da Tese de Doutorado, em sessão

pública realizada a

( ) Aprovado(a) considerou

\section{( ) Reprovado(a)}

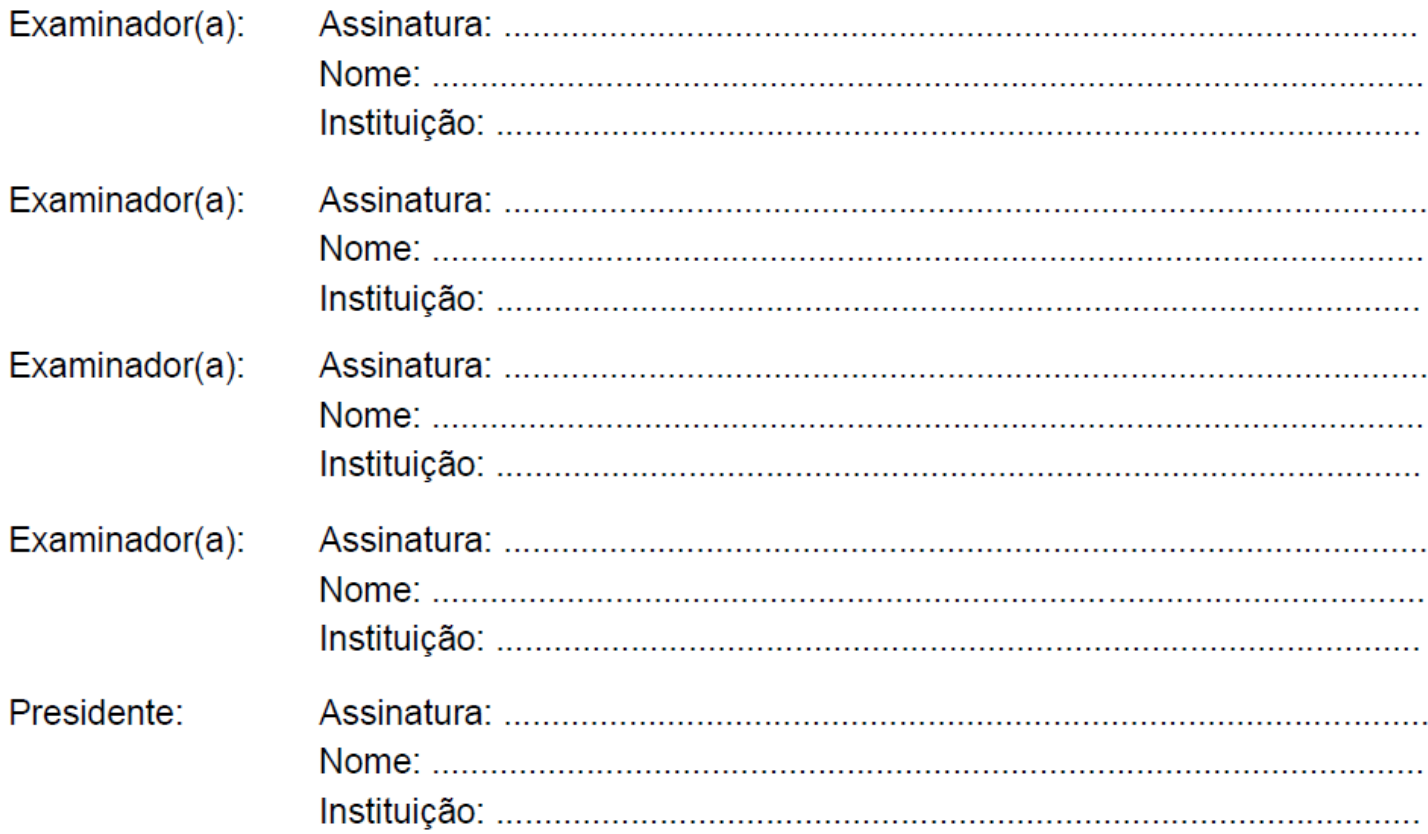




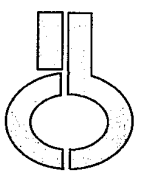

UNIVERSIDADE DE SÃO PAULO

INSTITUTO DE CIÊNCIAS BIOMÉDICAS

Cidade Universitária "Armando de Salles Oliveira"

Av. Prof. Lineu Prestes, 2415 - CEP. 05508-000 São Paulo, SP - Brasil

Telefone: :(55) (011) 3091.7733 - telefax : (55) (011) 3091.7438

e-mail: cep@icb.usp.br

\section{Certificado}

Certificamos que o protocolo registrado sob $n^{\circ} 101$ nas fls. 74 do livro 02 para uso de animais em experimentação, sob a responsabilidade do Prof(a) $\operatorname{Dr}(a)$ José Roberto Machado Cunha da Silva, Coordenador(a) da Linha de pesquisa Avaliação histopatológica do tratamento do carcinoma espinocelular cutâneo em camundongos usando terapia fotodinâmica mediada por azul metileno do qual participou(aram) o(s) alunos Ana Paula da Silva e o pesquisador Francisco Javier Hernandez Blazquez, está de acordo com os Principios Éticos de Experimentação Animal adotado pela Sociedade Brasileira de Ciência de Animais de Laboratório (SBCAL) e foi aprovado pela COMISSÃO DE ÉTICA EM EXPERIMENTAÇÃO ANIMAL (CEEA) em 15.09.09, com validade de 3 anos.

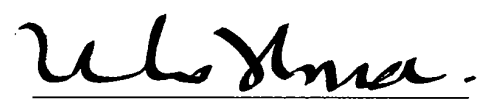

Prof.Dr.WOTHAN TAVARES DE LIMA Coordenador CEEA - ICB/USP
São Paulo, 09 de novembro de 2009.

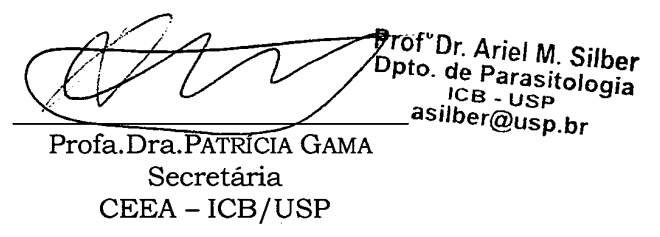




\section{UNIVERSIDADE de são PAULO}

\section{INSTITUTO DE CIÊNCIAS BIOMÉDICAS}

Cidade Universitária "Armando de Salles Oliveira"

. Prof. Lineu Prestes, 2415 - cep. 05508000 Săo Paulo, SP - Brasil

Telefone :(55) (011) 3091.7733 e-mail: cep@icb.usp.br

Of.CEUA.077.12

WTL/mogn

São Paulo, 25 de setembro de 2012.

REF.: Protocolo $n^{\circ}$ 101/09.

"Avaliação histopatológica do tratamento do carcinoma espinocelular cutâneo em camundongos usando terapia fotodinâmica mediada por azul metileno"

Prezado Professor

Informo que a sua licença para uso de animais em experimentação, constante no protocolo em epígrafe, fol prorrogada até 20.10.2015.

Reitero que havendo alteração de metodologia e inserção de novos alunos ao projeto de pesquisa vinculado à referida licença a CEUA/ICB deverá ser informada.

Cordialmente,

\section{Throm}

Prof. Dr. WOTHAN TAVARES DE LIMA

Coordenador- CEUA-ICB/ /USP

IImo.Sr.

Prof. Dr. José Roberto Machado Cunha da Silva

Départamento de Biologia Celular e do Desenvolvimento - ICB/USP 


\section{Comissão de Ética no uso de animais}

\section{CERTIFICADO}

Certificamos que o Projeto intitulado: "Avaliação histopatológica do tratamento do carcinoma espinocelular cutâneo em camundongos usando terapia fotodinâmica mediada por azul de metileno", protocolado sob o n¹857/2009, utilizando 100 (cem) camundongos, sob a responsabilidade da Profa Dra Maria Lúcia Zaidan Dagli, está de acordo com os princípios éticos de experimentação animal da "Comissão de Ética no uso de animais" da Faculdade de Medicina Veterinária e Zootecnia da Universidade de São Paulo e foi aprovado em reunião de $20 / 01 / 2010$.

We certify that the Research "Histopathologic evaluation of the treatment of squamous cell skin carcinoma in mice using photodynamic therapy mediated methylene blue", protocol number 1857/2009, utilizing 100 (one hundred) mice, under the responsibility Profa Dra Maria Lúcia Zaidan Dagli, agree with Ethical Principles in Animal Research adopted by "Ethic Committee in the use of animals" of the School of Veterinary. Medicine and Animal Science of University of São Paulo was approved in the meeting of day 01/20/2010.

São Paulo, 21 de janeiro de 2010

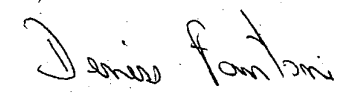

Profa Dra Denise Tabacchi Fantoni

Presidente 
A Deus e Nossa Senhora, fé de que tudo posso, fortaleza diante de situações difíceis, perseverança da vitória de um sonho realizado.

Aos meus pais Osvaldo João da Silva e Maria de Oliveira Lima da Silva pelo amor, apoio incondicional, confiança, carinho, conselhos, incentivos, pelos ensinamentos de humildade e persistência para alcançar os objetivos com dignidade. 


\section{AGRADECIMENTOS}

Ao Prof. Dr. José Roberto Machado Cunha da Silva pela confiança, acolhimento e oportunidade de crescer profissionalmente. Pelo exemplo de humildade, respeito e amizade.

Ao Prof. Dr. Francisco Javier Hernandez-Blazquez pelos ensinamentos, respeito e exemplo de profissionalismo.

Ao Prof. Dr. Maurício Baptista da Silva e pela idéia na elaboração deste projeto, pelas sugestões no exame de qualificação, pela confiança, pela colaboração e atenção nos momentos de dúvidas.

Ao Dr. Divinomar Severino pela amizade, idéia na elaboração deste projeto, pela ajuda nos dias da aplicação da TFD e colheita do material e pela confiança, apoio em todos os momentos.

Ao Prof. Dr. Bruno Cogliati pela amizade, respeito, pela colaboração na parte prática pela permissão do uso de equipamentos no seu laboratório e pela colaboração no esclarecimento de dúvidas, sempre com muito profissionalismo.

À Prof ${ }^{a}$. Dra . Maria Lúcia Zaidan Dagli pela imensa ajuda com os trâmites para o uso do Biotério no Departamento de Patologia da Faculdade de Medicina Veterinária e Zootecnia da Universidade de São Paulo e também pela permissão de trabalhar em seu laboratório quando foi necessário.

À minha amiga Elizangela dos Anjos Silva por novamente tirar uma grande parte do seu tempo me auxiliando com as correções do trabalho, pela ajuda na colheita do material de estudo e trabalho no biotério, eu agradeço imensamente pela companhia, amizade por todos esses anos e momentos de risadas bobas e muita descontração.

À Camila Lima Neves, aluna de Iniciação Científica que contribuiu muito com a elaboração deste trabalho, pela confiança, amizade, dedicação e responsabilidade. 
À minha amiga Tânia Cristina Lima Portela que esteve sempre ao meu lado nos momentos bons e difícieis. Pela ajuda pela ajuda na colheita do material de estudo e trabalho no biotério. Eu agradeço pela convivência com uma pessoa tão especial que sempre esteve disposta a auxiliar qualquer pessoa que pedisse pela sua ajuda, obrigada pela companhia, amizade e exemplo de simplicidade.

Aos colegas do Laboratório de Histofisiologia Evolutiva por todos os momentos passados juntos, pelas risadas, pelo carinho e apoio: Alfonso Braga Bartolini Salibeni Vivai, Aline Diniz, Débora Alves Leite Figueiredo, Douglas Amaral dos Santos, Gabriel Neto, Joana Mona e Pinto, Karina Fernandes Oliveira Rezende, Lígia Maria Salvo, Luciana Dzik, Paola Cristina Branco, Renan Evaristo e Yoel Rodriguez Pinto. Em especial, a Renata Stecca Iunes que me ajudou com a técnica de RT-PCR em tempo real, sua contribuição foi valiosa muito obrigada. Ao Andrews Krupinski Emerenciano que me ajudou a resolver muitas coisas burocráticas sempre de forma generosa. Leandro Nogueira Pressinotti e Ricardo Moraes Borges pelas conversas, sugestões e trocas de experiências.

À técnica de laboratório Emília pelo apoio técnico, ensinamentos e paciência.

Aos amigos, Alex Sander Dias Machado e Thaís Gaiad Machado e família, obrigada pelo abrigo no início desta jornada, sem esta ajuda nada disso teria acontecido. Obrigada pelo acolhimento não só na casa, mas na família. Vocês são inesquecíveis.

Aos amigos, Carlos Portela e João Carlos Shimada Borges pela amizade que criamos recentemente, vocês dois foram muito importantes nos momentos mais difíceis, obrigada pelo apoio e carinho.

Aos amigos, Gisele Saviani, Fernanda Agreste, Tereza Cristina da Silva, Diogo Palermo, Cida, Larissa Patrícia, Domenico Marra Duarte. Em especial, Cintia Maria Monteiro de Araújo e Thiago Pinheiro Arrais Aloia pela ajuda na colheita do material. A todos obrigada pela amizade e momentos especiais passados juntos.

Aos amigos da Pós Graduação pela troca de experiência, pelas risadas, desabafos, abraços em momentos difíceis. Obrigada: Adam Arai, Eloíza Rezende, Fábio Feitosa, Felipe da Costa Souza, Fernanda Serachi, Lázaro Oliveira, Maraysa Melo, Tatiane Kanno e Tatiani Donato. 
Aos amigos de Umuarama: Daniely Ganacin Fernandes, Douglas Fernandes, Vilma Xavier Cerialli, Jacqueline Guimarães, Ana Paula Machado, Patrícia Amati Graci, Jane Xavier, Efigênia Maria de Jesus, Edson Gerônimo, Marli Dias Machado e João Dias Machado eu agradeço pela paciência e por estarem sempre ao meu lado.

A toda minha família, tios (as), primos (as), minha madrinha Júlia e meu padrinho Jurandir (in memorian).

Aos meus avós João (in Memorian) e Helena e José (in Memorian) e Rita pelo amor e exemplo de vida.

Aos professores do Departamento de Biologia Celular e do Desenvolvimento pelos ensinamentos, preocupação com os alunos e pelo clima de amizade. Ao Prof. Jarbas Bauer, "tio Bauer" pelo exemplo de dedicação e amor pela docência. A Prof ${ }^{a}$. Marinilce Fagundes dos Santos por suas palavras no momento que eu precisei de incentivo e pelo exemplo de profissionalismo.

Às professoras Vanessa Morais Freitas e Luciana Correa pelas sugestões durante o exame de qualificação.

Aos secretários de Pós Graduação Regina Cássia Valbom, Celiana Marchiori, Paulo Vinicius Galvão Ambrozio, Virginia Miguel Gonçalves, Eloise Piva Cícero de Sá e Ana Lúcia Teixeira de Lima Mota pelo apoio nos trâmites e burocracia e paciência para tirar dúvidas.

Aos funcionários da biblioteca pela revisão desta tese.

Aos funcionários do ICB pela ajuda em alguma parte deste trabalho.

Aos meus animais de estimação Leão e Pretinha pelo companheirismo e alegria que me proporcionaram durante essa fase da minha vida.

A todos que torceram por mim sem me conhecer direito, mas contribuíram de alguma maneira com um sorriso. 
Aos meus pais, Osvaldo João da Silva e Maria de Oliveira Lima da Silva por sonhar junto comigo, pelo apoio nos momentos que tudo parecia tão improvável e incerto. Suas palavras ou mesmo o silêncio sempre me fortaleceram, obrigada por entenderem os anos de distância e que tudo iria dar certo no momento propício. Vocês não puderam completar os anos de estudos, mas sempre me incentivaram mesmo sem compreender exatamente o que faço. Obrigada por estarem ao meu lado nos melhores e nos piores dias da minha vida.

À Fundação de Amparo à Pesquisa do Estado de São Paulo (FAPESP) pela bolsa concedida (2009/51336-3) e auxílio à pesquisa relacionado a este projeto (2010/52675-3) e a Coordenação de Aperfeiçoamento de Pessoas de Nível Superior (CAPES) pelo apoio financeiro. 
"O correr da vida embrulha tudo. A vida é assim; esquenta e esfria, aperta e depois afrouxa, sossega e depois desinquieta. $\mathrm{O}$ que ela quer da gente é coragem. O que Deus quer é ver a gente aprendendo a ser capaz de ficar alegre e amar, no meio da tristeza. Todo o caminho da gente é resvaloso. Mas também cair não prejudica demais. A gente levanta, a gente sobe, a gente volta."

João Guimarães Rosa 


\section{RESUMO}

SILVA, A. P. Avaliação histopatológica do tratamento do carcinoma espinocelular cutâneo em camundongos usando terapia fotodinâmica mediada por azul de metileno. 2014. 119 f. Tese (Doutorado em Biologia Celular e Tecidual) - Instituto de Ciências Biomédicas, Universidade de São Paulo, São Paulo, 2014.

A terapia fotodinâmica (TFD) é uma modalidade clínica para tratar uma variedade de neoplasias, doenças de pele e representa um promissor tratamento estético. O princípio desta terapia é combinar moléculas fotossensibilizadoras com uma fonte de luz e oxigênio com o propósito de gerar espécies reativas de oxigênio (ERO) e/ou oxigênio singleto $\left({ }^{1} \mathrm{O}_{2}\right)$ que provocam citotoxicidade no tecido alvo. Os mecanismos de morte celular relatados na TFD incluem apoptose ou necrose, ativação do sistema imune ou danos na vascularização. $O$ azul de metileno (AM) é um fotossensibilizador (FS) capaz de gerar altas concentrações de ${ }^{1} \mathrm{O}_{2}$, pois possui boa absorção de fótons dentro do espectro vermelho da luz visível $(>630 \mathrm{~nm})$, ideal para atingir a janela terapêutica $(600-800 \mathrm{~nm})$ e ter efeito fotodinâmico. $\mathrm{O}$ carcinoma espinocelular cutâneo (CEC) é um tipo de câncer de pele frequente, tanto em humanos como em animais. O modelo experimental in vivo utilizando carcinógenos químicos 7,12 Dimethylbenz(A)anthracene (DMBA) e 12-O-tetradecanoylphorbol-13-acetato (TPA) mimetiza as condições histopatológicas e moleculares do desenvolvimento do CEC em humanos. O presente trabalho avaliou os aspectos histopatológicos e moleculares do tratamento pela TFD mediada por AM (TFD-AM) no modelo experimental do CEC in vivo e na pele sadia de camundongos Swiss. O protocolo da TFD foi de uma única sessão, com aplicação por injeção da solução de AM a $1 \%$ seguido por irradiação com laser diodo na dose total de $24 \mathrm{~J} / \mathrm{cm}^{2}$ nos tecidos tumorais e sadios. Os animais foram sacrificados em dois períodos, 24 horas e 15 dias após tratamento. A morfologia macroscópica foi acompanhada por fotografias e o tamanho tumoral foi medido por paquímetro. As respostas após a TFD foram obtidas pela avaliação histopatológica, pela quantificação do colágeno, análise de citocinas, avaliação imuno-histoquímica dos marcadores PCNA, caspase 3 clivada, CD8, fator de von Willebrand e análise por imuno-histoquímica e RT-PCR em tempo real dos marcadores H-ras, p53, Bak e Bcl-xL. A TFD-AM diminuiu o tamanho em diâmetro dos tumores, por causa de necrose ou ulcerações na superfície destes tumores. Alterações morfológicas foram pouco marcantes nos tecidos tumorais tratados, entretanto, foram mais pronunciadas nos tecidos sadios que apresentaram aumento na espessura epitelial e diminuição de fibras colágenas. O grupo sadio no período de 15 dias após a TFD apresentou infiltrado inflamatório na derme, presença de fibroblastos reativos, maior índice de células marcadas pela caspase 3 clivada, aumento nos níveis plasmáticos de TNF- $\alpha$ e IL- $1 \beta$, aumento no número de vasos marcados pelo fator de von Willebrand, aumento na expressão gênica de Bak e H-ras indicando que estas alterações estão relacionadas ao processo de remodelamento das áreas danificadas pela TFD. Embora, o tratamento pela TFD-AM não foi efetivo em provocar morte das células tumorais, houve diminuição no índice de células marcadas pelo PCNA e na expressão de genes alvos no desenvolvimento do CEC. Podemos concluir que os efeitos de uma única sessão da TFD mediada pelo AM na dose aplicada não conferiu melhora no tratamento do CEC. Estes resultados motivam novos estudos com ajustes no protocolo para melhorar a eficácia desta terapia.

Palavras-chave: Carcinoma espinocelular cutâneo. Pele. Terapia fotodinâmica. Azul de metileno. Camundongos. DMBA/TPA. 


\begin{abstract}
SILVA, A. P. Histopathological evaluation of the treatment of cutaneous squamous cell carcinoma in mice using photodynamic therapy mediated by methylene blue. 2014. 119 p. Ph. D. thesis (Cell and Tissue Biology) - Instituto de Ciências Biomédicas, Universidade de São Paulo, São Paulo, 2014.
\end{abstract}

Photodynamic therapy (PDT) is a clinical method for treating a variety of cancers, skin disorders and represents a promising cosmetic treatment. The principle of this therapy is to combine photosensitizing molecules with a light source and oxygen in order to generate reactive oxygen species (ROS) and/or singlet oxygen $\left({ }^{1} \mathrm{O}_{2}\right)$ that cause cytotoxicity in the target tissue. The reported mechanisms of cell death in PDT include apoptosis or necrosis, activation of the immune system or damage to the vasculature. Methylene blue (MB) is a photosensitizer (PS) can generate high concentrations of ${ }^{1} \mathrm{O}_{2}$, because it has good absorption of photons in the red spectrum of visible light $(>630 \mathrm{~nm}$ ), to achieve optimal therapeutic window $(600-800 \mathrm{~nm})$ have photodynamic effect. The cutaneous squamous cell carcinoma (SCC) is a common type of skin cancer in both humans and animals. The in vivo experimental model using chemical carcinogens 7,12 dimethylbenz (A) anthracene (DMBA) and 12-O-tetradecanoylphorbol-13-acetate (TPA) mimics the histopathological and molecular conditions of the development of SCC in humans. This study evaluated the histopathological and molecular aspects of treatment by PDT mediated MB (PDT-MB) in an experimental model of SCC in vivo and in healthy skin of Swiss mice. The PDT protocol was a single session, with the application of injection solution $\mathrm{MB}$ to $1 \%$ followed by diode laser irradiation at a total dose of $24 \mathrm{~J} / \mathrm{cm}^{2}$ in tumor and healthy tissues. The animals were sacrificed at two periods, 24 hours and 15 days after treatment. The macroscopic morphology was accompanied by photographs and tumor size was measured by caliper. Responses were obtained after PDT for histopathological evaluation, by quantification of collagen, cytokine analysis, immunohistochemical analysis by immunohistochemistry of markers PCNA, cleaved caspase-3, CD8, von Willebrand factor and analysis of markers by RT-PCR time real H-ras, p53, Bak and Bcl-xL. The PDT-MB decreased the size of tumors in diameter because of necrosis or ulceration of the surface of these tumors. Morphological changes were somewhat striking in treated tumor tissues, however, were more pronounced in healthy tissues that showed increased epithelial thickness and decreased collagen fibers. The healthy group 15 days after PDT showed inflammatory infiltrate in the dermis, presence of reactive fibroblasts, higher rate of cells labeled for cleaved caspase 3, increased plasma levels of TNF$\alpha$ and IL-1 $\beta$, increased number of vessels marked by the von Willebrand factor, increased gene expression of Bak and $\mathrm{H}$-ras indicating that these changes are related to a remodeling process areas damaged by PDT. Although, treatment by PDT-MB was not effective in causing cell death of tumor, resulted in reduction in the PCNA index and expression of target genes in the development of SCC. We conclude that the effects of a single session of PDTmediated MB on applied dose conferred no improvement in the treatment of SCC. These results motivate further studies with adjustments to the protocol to improve the effectiveness of this therapy.

Keywords: Squamous cell Carcinoma. Skin. Photodynamic therapy. Methylene blue. Mice. DMBA/TPA. 


\section{LISTA DE ILUSTRAÇÕES}

Figura 1 - Mecanismos de ação da TFD, reação tipo I e II.

Figura 2 - Principais mecanismos de morte celular causados pela Terapia Fotodinâmica.... 36

Figura 3 - Espectro de absorção do azul de metileno em meio aquoso 37

Figura 4 - Via intrínseca da apoptose.

Figura 5 - Tratamento dos tumores de pele pela Terapia Fotodinâmica

Figura 6 - Período experimental

Quadro 1 - Assays para análise da expressão gênica por RT-PCR em tempo real.....

Figura 7 - Curva de sobrevivência dos camundongos controles e tratados.

Figura 8 - Diferentes estágios do desenvolvimento dos tumores de pele induzidos em camundongos Swiss pelos carcinógenos DMBA/TPA.

Figura 9 - Imagens representativas da regressão dos tumores de pele induzidos em camundongos Swiss pelos carcinógenos DMBA/TPA.

Figura 10 - Diâmetro dos tumores $(\mathrm{mm})$ nos grupos experimentais 66

Figura 11 - Alterações macroscópicas depois do tratamento pela TFD 67

Figura 12 - Classificação Histopatológica dos Tumores. 70

Figura 13 - Morfologia microscópica após a TFD dos grupos induzidos ao CEC em diferentes aumentos

Figura 14 - Morfologia microscópica após a TFD dos grupos sadios em diferentes aumentos.

Figura 15 - Morfologia das fibras colágenas dos grupos induzidos ao CEC e grupos sadios.

Figura 16 - Fotomicrografias representativas da imunomarcação pelo PCNA .77

Figura 17 - Fotomicrografias representativas da técnica de TUNEL. 79

Figura 18 - Fotomicrografias representativas da marcação imuno-histoquímica pela caspase 3 clivada.

Figura 19 - Fotomicrografias representativas da marcação imuno-histoquímica pelo CD8. 
Figura 20 - Níveis plasmáticos de citocinas $(\mathrm{pg} / \mathrm{mL})$.

Figura 21 - Fotomicrografias representativas da marcação imuno-histoquímica pelo fator de von Willebrand (fvW)

Figura 22 - Fotomicrografias representativas da marcação imuno-histoquímica de H-ras... 86

Figura 23 - Expressão do gene H-ras. 88

Figura 24 - Fotomicrografias representativas da marcação imuno-histoquímica de p53 ..... 89

Figura 25 - Expressão do gene p53 91

Figura 26 - Fotomicrografias representativas da marcação imuno-histoquímica de Bak...... 92

Figura 27 - Expressão do gene Bak

Figura 28 - Fotomicrografias representativas da marcação imuno-histoquímica de Bcl$\mathrm{xL}$ .95

Figura 29 - Expressão do gene Bcl-xL .97 


\section{LISTA DE TABELAS}

Tabela 1 - Delineamento dos grupos experimentais.

Tabela 2 - Colheita do material biológico e distribuição entre os fixadores.

Tabela 3 - Anticorpos e suas especificações. 56

Tabela 4 - Média e desvio padrão do peso corporal dos animais durante o período experimental

Tabela 5 - Escores da intensidade da marcação imuno-histoquímica de H-ras nas amostras controles e tratadas do carcinoma espinocelular cutâneo e peles sadias em diferentes estratos da epiderme. Valores expressos como mediana (valor mínimo e máximo, respectivamente) 87

Tabela 6 - Escores da distribuição da marcação imuno-histoquímica de H-ras em amostras controles e tratadas do carcinoma espinocelular cutâneo e peles sadias

Tabela 7 - Escores da intensidade da marcação imuno-histoquímica de p53 nas amostras controles e tratadas do carcinoma espinocelular cutâneo e peles sadias em diferentes estratos da epiderme. Valores expressos como mediana (valor mínimo e máximo, respectivamente).90

Tabela 8 - Escores da distribuição da marcação imuno-histoquímica de p53 em amostras controles e tratadas do carcinoma espinocelular cutâneo e peles sadias

Tabela 9 - Escores da intensidade da marcação imuno-histoquímica de Bak nas amostras controles e tratadas do carcinoma espinocelular cutâneo e peles sadias em diferentes estratos da epiderme e na derme. Valores expressos como mediana (valor mínimo e máximo, respectivamente)

Tabela 10 - Escores da distribuição da marcação imuno-histoquímica de Bak em amostras controles e tratadas do carcinoma espinocelular cutâneo e peles sadias

Tabela 11 - Escores da intensidade da marcação imuno-histoquímica de Bcl-xL nas amostras controles e tratadas do carcinoma espinocelular cutâneo e peles sadias em diferentes estratos da epiderme e na derme. Valores expressos como mediana (valor mínimo e máximo, respectivamente).

Tabela 12 - Escores da distribuição da marcação imuno-histoquímica de Bcl-xL em amostras controles e tratadas do carcinoma espinocelular cutâneo e peles sadias 


\section{LISTA DE ABREVIATURAS E SIGLAS}

$\begin{array}{ll}> & \text { maior } \\ \boldsymbol{\mu g} & \text { micrograma } \\ \boldsymbol{\mu l} & \text { microlitro } \\ \boldsymbol{\mu m} & \text { micrômetro } \\ \boldsymbol{\mu s} & \text { microssegundo } \\ { }^{\mathbf{1}} \mathbf{O}_{\mathbf{2}} & \text { oxigênio singleto }\end{array}$

Al alumínio

ALA ácido 5-aminolevulínico (do inglês, 5 -Aminolevulinic acid)

AlCIPc do inglês, aluminum phthalocyanine chloride

AM azul de metileno

AP-1 ativador proteico 1

APC célula apresentadora de antígeno (do inglês, antigen-presenting cell)

AsGaAl arsenieto de gálio e alumínio

ATP adenosina trifosfato

C citosina

CBC carcinoma basocelular

CDKs quinases dependentes de ciclinas (do inglês, cyclin dependent kinases)

cDNA DNA complementar

Ce $\quad$ clorina e6

CEC carcinoma espinocelular cutâneo

CPM câncer de pele melanoma

CPNM câncer de pele não melanoma

Cyt c citocromo c

DAB do inglês, 3'3-Diaminobenzidine

DMBA do inglês, 7,12 dimethylbenz(A)anthracene

DNA ácido desoxirribonucleico

DNase deoxirribonuclease

dNTPS deoxinucleotideo trifosfato

DP desvio padrão

EDTA ácido etilenodiamino tetra-acético (Ethylenediamine tetraacetic acid)

EGFR receptor do fator de crescimento epidermal

ELISA do inglês, Enzyme-Linked Immunosorbent Assay 


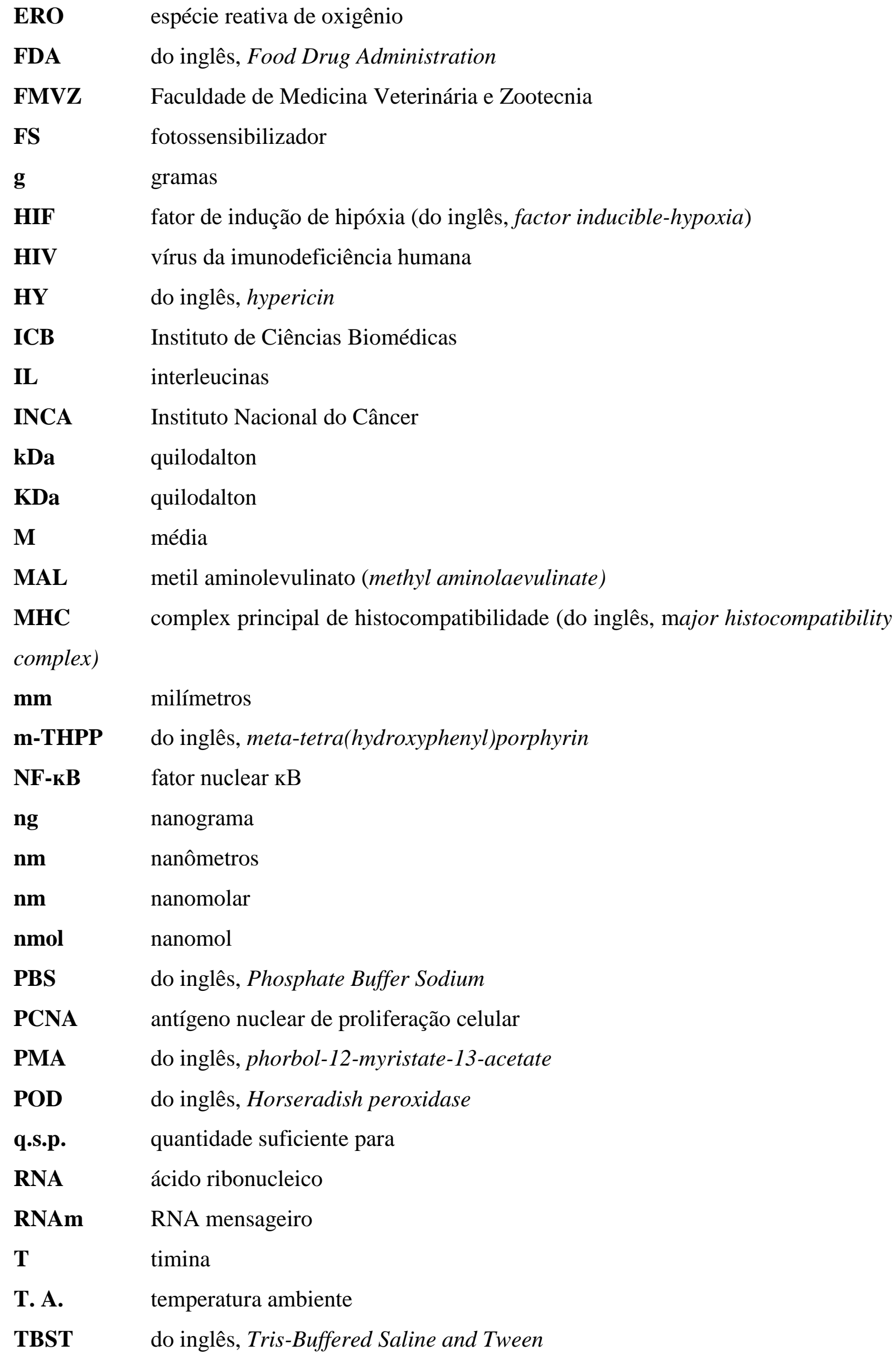


TdT do inglês, terminal deoxynucleotidyl transferase

TFD terapia fotodinâmica

TGF $\beta 1 \quad$ fator de crescimento transformador beta 1

TNF fator de necrose tumoral

TPA do inglês, 12-O-tetradecanoylphorbol-13-acetato

TUNEL do inglês, terminal deoxynucleotidyl transferase-mediated dUTP nick endlabeling

USP Universidade de São Paulo

UV ultravioleta

VEGF fator de crescimento do endotélio vascular (vascular endotelial growth fator)

Zn zinco 


\section{SUMÁRIO}

1 INTRODUÇÃO …….................................................................................................................... 24

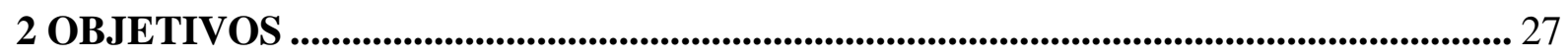

2.1 OBJETIVO GERAL ........................................................................................................... 27

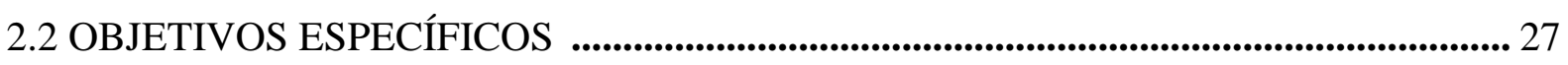

3 REVISÃO DE LITERATURA............................................................................... 28

3.1 CARCINOMA ESPINOCELULAR CUTÂNEO .............................................................. 28

3.1.1 Indução do Carcinoma Espinocelular Cutâneo............................................................... 30

3.1.2 Genes Alvos no Desenvolvimento do Carcinoma Espinocelular Cutâneo ............... 32

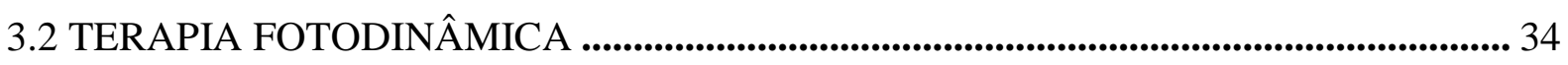

3.2.1 Terapia Fotodinâmica mediada por Azul de Metileno ……………............................... 37

3.3 EFEITOS BIOLÓGICOS APÓS TERAPIA FOTODINÂMICA ......................................... 39

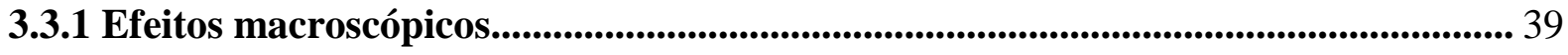

3.3.2 Efeitos na histopatologia tumoral e no colágeno tipo I ................................................. 40

3.3.3 Efeitos na regulação do ciclo celular e apoptose.............................................................. 41

3.3.4 Efeitos no sistema imune.............................................................................................. 45

3.3.5 Efeitos na vascularização .................................................................................................. 47

4 MATERIAL E MÉTODOS ....................................................................................... 50

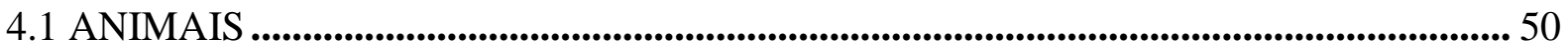

4.2 MODELO DE INDUÇÃO DO CARCINOMA ESPINOCELULAR CUTÂNEO .......... 50

4.3 TRATAMENTO PELA TERAPIA FOTODINÂMICA....................................................... 50

4.4 DELINEAMENTO EXPERIMENTAL ......................................................................... 51

4.4.1 Formação dos Grupos Experimentais ......................................................................... 51

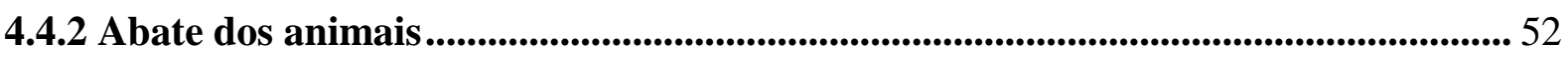

4.5 FIXAÇÃO E PROCESSAMENTO DO MATERIAL BIOLÓGICO ................................... 52

4.6 AVALIAÇÃO MACROSCÓPICA ............................................................................ 53

4.7 AVALIAÇÃO HISTOPATOLÓGICA .............................................................................. 53

4.8 AVALIAÇÃO DO COLÁGENO TIPO I .......................................................................... 54

4.9 TÉCNICA DE IMUNO-HISTOQUÍMICA .................................................................... 55

4.10 TÉCNICA DE TUNEL (terminal deoxynucleotidyl transferase-mediated dUTP nick endlabeling)................................................................................................................................. 57

4.11 TÉCNICA DE ELISA (Enzyme-Linked Immunosorbent Assay) ......................................... 58

4.12 AVALIAÇÃO DA EXPRESSÃO GÊNICA POR RT-PCR EM TEMPO REAL............59 


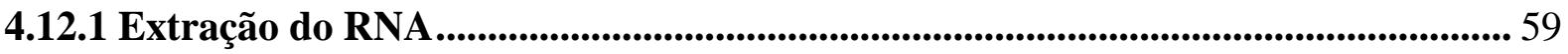

4.12.2 Determinação e Quantificação do RNA total.............................................................. 59

4.12.3 Obtenção do DNA complementar (cDNA) ........................................................ 60

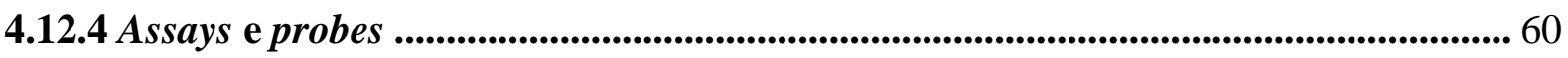

4.12.5 Quantificação da expressão gênica por PCR em tempo real..................................60

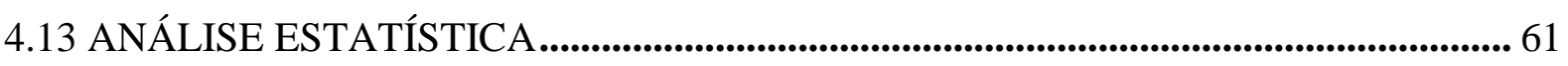

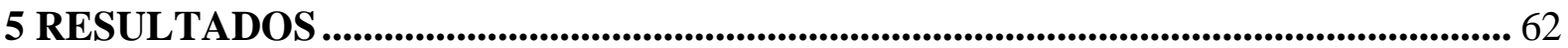

5.1 ASPECTOS MACROSCÓPICOS ............................................................................................... 62

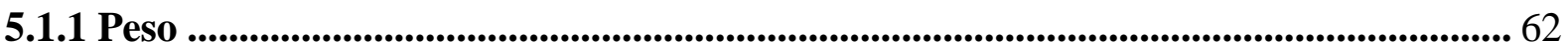

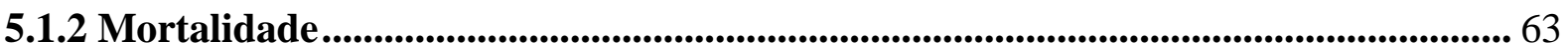

5.1.3 Desenvolvimento dos tumores ............................................................................................. 63

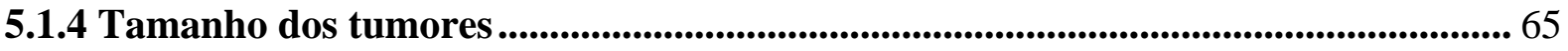

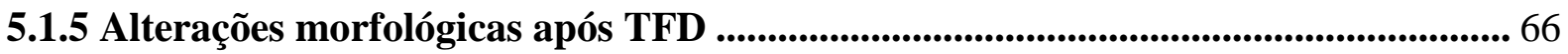

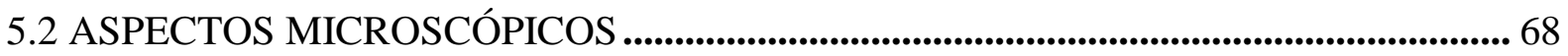

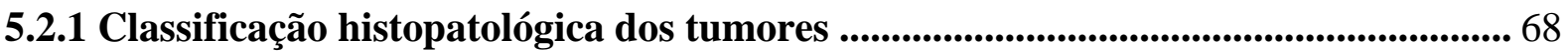

5.2.2 Avaliação histopatológica após a TFD............................................................. 71

5.2.3 Avaliação do depósito de colágeno tipo I........................................................... 74

5.2.4 Imuno-histoquímica para PCNA ............................................................................... 76

5.2.5 Avaliação dos marcadores de apoptose pelo TUNEL e Caspase 3 clivada .............. 77

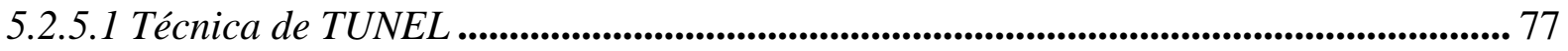

5.2.5.2 Imuno-histoquímica para Caspase 3 clivada ............................................................. 79

5.2.6 Avaliação do sistema imune celular pela marcação imuno-histoquímica de CD8 e níveis plasmáticos das citocinas TNF-alpha, IL-1Beta e IL-2 pela técnica de ELISA .... 81 5.2.6.1 Imuno-histoquímica para CD8 ............................................................................ 81

5.2.6.2 Técnica de ELISA para avaliação de citocinas ............................................................ 82

5.2.7 Avaliação da vascularização pela marcação imuno-histoquímica do fator de von

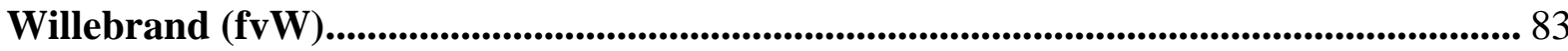

5.2.8 Avaliação da expressão imuno-histoquímica e expressão gênica por RT-PCR em alvos moleculares envolvidos no desenvolvimento do CEC .............................................. 84

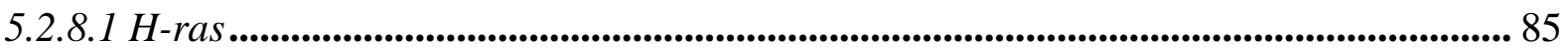

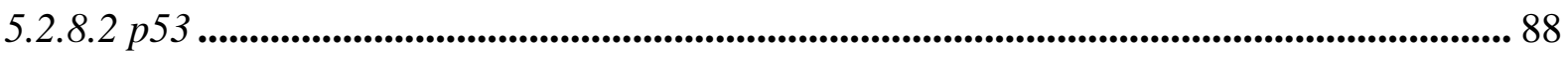

5.2.9 Avaliação da expressão imuno-histoquímica e expressão gênica por RT-PCR em alvos moleculares envolvidos na regulação da apoptose ............................................................ 91

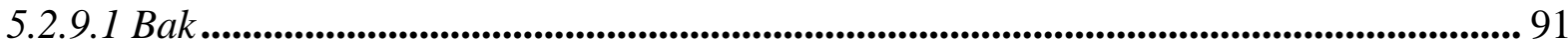




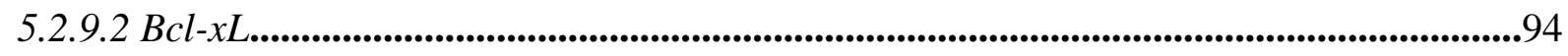

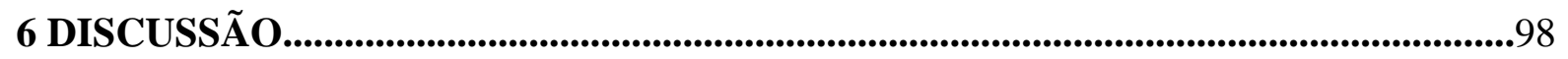

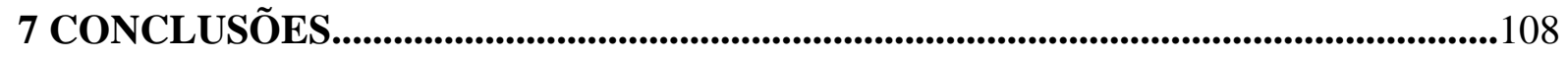

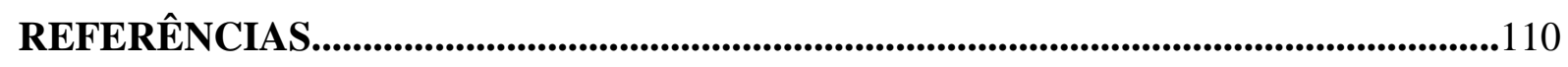




\section{INTRODUÇÃO}

A terapia fotodinâmica (TFD) é uma modalidade terapêutica aprovada para o tratamento curativo e paliativo de alguns tipos de cânceres, lesões pré-neoplásicas, algumas doenças de pele e degeneração macular (JUARRANZ et al., 2008). A TFD usa moléculas fotossensibilizadoras, que são corantes ou pigmentos capazes de absorver luz visível e que induzem ou participam de reações fotoquímicas. Escolhido o fotossensibilizador (FS), este é injetado no tecido alvo, que sob a excitação de uma luz com o comprimento de onda adequado resultará em dano e/ou subsequente morte celular, por meio da geração de subprodutos citotóxicos aproveitando o oxigênio endógeno dissolvido nas células. Pode-se resumir que a TFD é uma combinação que envolve luz, FS e oxigênio (KUBLER, 2005; TARDIVO et al., 2005).

A TFD trata seletivamente lesões tumorais sem causar prejuízos aos tecidos adjacentes sadios. Os principais mecanismos de ação da TFD para destruir células tumorais são: danos diretos, levando as células tumorais à morte por apoptose ou necrose; danos indiretos, pela destruição da vascularização do tumor ou pela ativação da resposta imune contra as células tumorais (MROZ et al., 2011; JUARRANZ et al., 2008).

Desde 1995, a Federal Drug Administration (FDA) dos Estados Unidos aprovou o uso da TFD para tratamento paliativo de carcinomas obstrutivos do esôfago, lesões malignas e pré-malignas da pele. Em alguns países, o uso para tratamento de câncer de pulmão, esôfago, bexiga e degeneração macular foi aprovado. Há muitas pesquisas abrangendo a utilização da TFD em tumores cerebrais, carcinomas de cabeça e pescoço, neoplasias ginecológicas e pâncreas. Existe também um crescimento de investigações em áreas não relacionadas ao câncer, como na dermatologia para tratamento de acne, psoríase, leishmaniose cutânea, verrugas virais e rejuvenescimento da pele (ARIAS et al., 2007; MROZ et al., 2011).

Os princípios da TFD foram descobertos ao acaso no início do século XX na Alemanha, quando Oscar Raab estudava os efeitos da acridina no protozoário do gênero Paramecium. Após o uso do corante sobre o micro-organismo exposto à luz, Raab observou que o protozoário sofreu dano celular que o levou à morte. O pesquisador Hermann von Tappeiner, orientador de Raab, após evidências da técnica em causar morte celular, conseguiu os primeiros resultados clínicos no tratamento do carcinoma basocelular (CBC) pelo uso da TFD. Após várias pesquisas com TFD foi possível isolar derivados de hematoporfirinas, as porfirinas junto com o ferro formam o grupo heme dos eritrócitos, estes compostos foram os primeiros FSs usados na TFD, por causa da alta afinidade destas moléculas com as células 
neoplásicas. Meyer-Betz quando estudou estes compostos autoinjetou hematoporfirinas na corrente sanguínea e sofreu fotossensibilização por dois meses (ACKROYD et al., 2001; KESSEL, 2004). A administração intravenosa dos derivados de hematoporfirinas tem desvantagem em causar acúmulo na pele após semanas de tratamento, isto acarreta em fotossensibilidade aos pacientes (ARIAS et al., 2007).

A tentativa de diminuir a fotossensibilização para os pacientes tratados ocasionou o desenvolvimento e a procura de novas moléculas fotossensibilizadoras. Com este avanço no desenvolvimento de novos compostos, a TFD pode ser administrada de forma sistêmica com injeção intravenosa, aplicação local ou tópica do FS. O desafio da TFD é o ajuste da técnica, pois o tipo de FS usado, iluminação, dosagens e tipo de tecido podem produzir diferentes respostas ao tratamento (JUARRANZ et al., 2008; MROZ et al., 2011; ROBERTSON; EVANS; ABRAHAMSE, 2009).

O azul de metileno (AM), molécula fotossensibilizadora, é um derivado fenotiazínico que pode gerar concentrações altas de oxigênio singleto $\left({ }^{1} \mathrm{O}_{2}\right)$ ou pode induzir a formação de espécies reativas de oxigênio (ERO) que são subprodutos formados pela TFD e causam toxicidade celular (SEVERINO et al., 2003; TARDIVO et al., 2005; WAINWRIGHT, 2005). O AM é pouco utilizado clinicamente como FS para o tratamento de lesões malignas, entretanto, estudos em modelos in vitro reportam o uso deste FS com sucesso para inativação de vários micro-organismos (PELOI et al., 2008; SONG et al., 2011).

Em países de clima tropical como o Brasil, com elevada exposição à radiação ultravioleta (UV), tanto o câncer de pele melanoma (CPM) como o tipo de câncer de pele não melanoma (CPNM) apresentam alta incidência em comparação a outros países de clima temperado. O carcinoma espinocelular cutâneo (CEC) é um tipo de CPNM, cujo tratamento mais utilizado é a excisão cirúrgica por possuir altas taxas de curas (BAHNER; BOURDEAUX, 2013). Portanto, pesquisas que beneficiem melhores resultados cosméticos, menor agressividade ao tratamento e custos mais baixos para os pacientes são importantes.

Estudos clínicos e in vitro têm fornecido informações relevantes sobre os efeitos da TFD em células neoplásicas. Contudo, quando o objetivo é examinar os efeitos de determinada molécula fotossensibilizadora ou novos protocolos de tratamento há limitações de testes em pacientes, pois há necessidade de avaliação prévia em modelos animais. $\mathrm{O}$ modelo in vitro tem suas limitações, pois a maioria das informações obtidas é difícil de reproduzir em organismos in vivo.

Mediante a necessidade de estudos in vivo esta pesquisa teve como finalidade utilizar um modelo experimental do CEC que foi induzido na pele de camundongos pela utilização 
dos carcinógenos químicos 7,12 Dimethylbenz(A)anthracene (DMBA) e 12-Otetradecanoylphorbol-13-acetato (TPA). Este modelo é muito utilizado em pesquisas para investigar drogas promissoras na prevenção do câncer, pois mimetiza bem o desenvolvimento do CEC que tem alta incidência em humanos (ABEL et al., 2009; KAUR; ATHAR; ALAM, 2010). Este modelo quando usado em pesquisas relacionadas à TFD, os tumores formados são qualificados como papilomas, sem a classificação criteriosa para distinguir lesões malignas das benignas. O presente trabalho propôs pela primeira vez classificar por avaliação histopatológica os tumores desenvolvidos para selecionar apenas lesões malignas para o estudo mais aprofundado das respostas teciduais após o tratamento pela TFD.

Há vários trabalhos clínicos e moleculares in vitro que relataram os efeitos da TFD, entretanto, pesquisas que evidenciem as respostas teciduais após tratamento são escassas. Com o crescente uso da TFD em variadas modalidades médicas, em especial, na dermatologia, tornou-se incontestável a necessidade de investigar respostas biológicas teciduais após uso da TFD. O presente trabalho teve como objetivo avaliar a curto e médio prazo se o tratamento pela TFD mediada por AM na pele de camundongos experimentalmente induzidos ao CEC melhorou, manteve ou regrediu. Esta pesquisa também avaliou as respostas da TFD na pele sadia, uma vez que, esse tratamento é promissor tanto na área de cancerologia como na cosmética dermatológica, em especial, na área de rejuvenescimento. Para verificar possíveis mudanças teciduais imediatas e com prazo maior, foram analisados dois períodos após o tratamento, 24 horas e 15 dias.

A hipótese desta pesquisa é que uma única aplicação da TFD-AM poderia causar alterações relevantes nos tecidos tratados, tendo como base os principais mecanismos de destruição tumoral pela TFD: indução da morte celular direta, ativação do sistema imune ou diminuição no número de vasos que impedissem a progressão da doença. Para esta pesquisa, critérios histopatológicos foram usados para observação das alterações macro e microscópicas dos tecidos tratados, associados a um painel imuno-histoquímico com marcadores relacionados ao ciclo celular, apoptose, sistema imune, vascularização e desenvolvimento do CEC. A quantificação de colágeno tipo I foi analisada, além da quantificação de citocinas próinflamatórias e a expressão de genes relacionados com a carcinogênese do CEC e com a regulação da apoptose. A compreensão das respostas teciduais e de marcadores moleculares in vivo é crucial para aprimorar protocolos clínicos da TFD. 


\section{OBJETIVOS}

\subsection{OBJETIVO GERAL}

Avaliar os efeitos da terapia fotodinâmica mediada por azul de metileno no tratamento do carcinoma espinocelular cutâneo e na pele sadia de camundongos em dois períodos, 24 horas e 15 dias após o tratamento.

\subsection{OBJETIVOS ESPECÍFICOS}

$\checkmark$ Validar o protocolo de carcinogênese dos tumores induzidos com uso de DMBA/TPA;

$\checkmark$ Realizar avaliação macroscópica dos tumores antes e após a TFD;

$\checkmark$ Realizar avaliação histopatológica dos tecidos tratados;

$\checkmark$ Examinar os efeitos da TFD na quantificação do colágeno tipo I;

$\checkmark$ Avaliar o índice de proliferação celular epitelial;

$\checkmark$ Avaliar o índice de células em apoptose;

$\checkmark$ Avaliar os efeitos da TFD sobre o sistema imune;

$\checkmark$ Examinar os efeitos da TFD sobre a vascularização;

$\checkmark$ Avaliar os efeitos da TFD em alvos moleculares envolvidos no desenvolvimento do CEC;

$\checkmark$ Analisar os efeitos da TFD em alvos moleculares envolvidos na regulação da apoptose. 


\section{REVISÃO DE LITERATURA}

\subsection{CARCINOMA ESPINOCELULAR CUTÂNEO}

O câncer é classificado como uma neoplasia maligna, no qual ocorre a hiperproliferação em determinado tipo celular que tende invadir outros tecidos próximos ou distantes. O que caracteriza uma célula neoplásica é uma ou mais modificações no seu material genético seguido por proliferação para fixar essa alteração, culminando com a formação tumoral (MICHOR; IWASA; NOWAK, 2004). Mutações nos genes que regulam o ciclo celular, as vias apoptóticas e vias de reparo aos danos do DNA contribuem na sobrevivência de células que apresentam instabilidade genômica, aumentando a incidência para o desenvolvimento do câncer (KASTAN; BARTEK, 2004).

O Instituto Nacional do Câncer (INCA) revelou que em 2014 e 2015 a estimativa para o Brasil é de aproximadamente 576 mil novos casos de câncer. O câncer de pele não melanoma foi indicado como o mais incidente (182 mil casos), nos homens 98.420 casos são esperados e nas mulheres 83.710 (INCA, 2014). Os principais tipos de câncer de pele compreendem: o câncer de pele não melanoma (CPNM) e o câncer de pele melanoma (CPM). O carcinoma basocelular (CBC) e o carcinoma espinocelular cutâneo (CEC) são caracterizados como CPNM (ARMSTRONG; KRICKER, 2001). A incidência do CPNM varia e apresenta altas taxas nas populações caucasianas no mundo. Embora, o CBC é o mais comum entre a população humana, o CEC é o mais invasivo provocando metástases e morte (BROUGHAM et al., 2012; SUÁREZ et al., 2007).

O CEC recebe outras denominações como carcinoma de células escamosas ou epidermoide. Esta neoplasia é constituída pela proliferação descontrolada de células do estrato espinhoso da epiderme (WILSON; EVANS, 2010). Há várias lesões pré-neoplásicas que dificultam o diagnóstico para o CEC, como queratose actínica, queratoacantoma e doença de Bowen. As primeiras lesões macroscópicas relacionadas ao CEC surgem como pápulas escamosas avermelhadas na pele que podem formar nódulos ou placas, estas lesões podem ulcerar (BOUKAMP, 2005; GARCIA-ZUAZAGA; OLBRICHT, 2008). A face é a região mais atingida nas mulheres e homens (ARMSTRONG; KRICKER, 2001). Tumores maiores que $2 \mathrm{~cm}$ no humano podem causar desfiguramento, recorrência e metástase (RENZI et al., 2010). O potencial de metástase do CEC é bem reconhecido em nódulos linfáticos, entretanto, em locais distantes da lesão primária são menos frequentes (BROUGHAM et al., 2012). 
A forma histológica do CEC incluem lençóis ou cordão de células epiteliais que se proliferam em direção à derme e hipoderme, são relativamente grandes e atípicas, apresentam núcleo pleomórfico e mitoses frequentemente atípicas. A célula individual exibe muita queratinização, possui forma cilíndrica, o citoplasma é opaco e intensamente eosinófilo e o núcleo é picnótico. A polarização das células basais é rara no CEC. As formas bem diferenciadas exibem pequenos focos de queratina dentro de nódulos tumorais (pérolas córneas), ocorre paraqueratose, além de pouca atividade mitótica e pleomorfismo mínimo. Os CECs poucos diferenciados apresentam pleomorfismo acentuado e escassa produção de queratina (BRODERS, 1921; WILSON; EVANS, 2010).

A análise histopatológica é a principal forma de diagnosticar o CEC, pois não há um biomarcador específico para esta neoplasia (GARCIA-ZUAZAGA; OLBRICHT, 2008). Broders (1921) propôs um método de classificação histopatológica do CEC com base no grau de diferenciação histológica sem associação com o percurso clínico do paciente. Os CECs foram classificados em grau I (mais de $75 \%$ de células bem diferenciadas), grau II (50 a 75\% de células bem diferenciadas) e grau III (25 a 50\% de células bem diferenciadas). Quanto maior o grau de diferenciação, menor é a tendência invasiva. A graduação proposta por Broders ainda é a base para classificação desta neoplasia.

A radiação UV é o principal fator de risco para o desenvolvimento do CEC, pois provoca danos ao DNA. A exposição solar aumenta com a diminuição da latitude, atingindo altos índices no nível do Equador (ARMSTRONG; KRICKER, 2001; NARAYANAN; SALADI; FOX, 2010). Os raios UV induzem mutações no DNA, em especial, no gene p53 causando transições das bases nitrogenadas $\mathrm{C}$ e $\mathrm{T}$ com alta frequência de trocas nas bases duplas de CC para TT (ARMSTRONG; KRICKER, 2001; BOUKAMP, 2005).

Além da radiação UV, outros fatores podem contribuir no desenvolvimento desta neoplasia, como infecções virais, exposição a arsênicos, dermatoses crônicas, resposta imune do hospedeiro, predisposição genética como epidermodisplasia verruciforme e xeroderma pigmentoso (GARCIA-ZUAZAGA; OLBRICHT, 2008). Indivíduos que sofreram terapia imunossupressora após transplante de órgãos sólidos são propensos a desenvolver o CEC (BOUKAMP, 2005). O CEC é considerado uma doença ocupacional, pois seu desenvolvimento está relacionado com algumas profissões que expõem os trabalhadores aos agentes etiológicos, como a radiação UV e produtos químicos, os trabalhadores da área rural e pedreiros são as profissões que registraram maior risco no desenvolvimento do CEC (SUÁREZ et al., 2007). 
Algumas opções de tratamento para o CEC se referem à excisão cirúrgica, crioterapia, eletrodissecção e curetagem, agentes quimioterápicos, radiação e outros. O tratamento do CEC mais empregado é a remoção cirúrgica, na qual tem por objetivo a erradicação do tumor com a preservação das estruturas ao redor, de forma esteticamente aceitável. A importância de estudar outros tratamentos não cirúrgicos para o CEC se refere, em especial, na obtenção de resultados cosméticos admissíveis, pois a excisão cirúrgica pode causar uma deformação significativa e prejuízo funcional dependendo da área lesionada. Entretanto, são muitos os fatores a considerar no tratamento do CEC, como a falta de ensaios clínicos padronizados, grandes variações no comportamento dos tumores que se inserem na categoria de diagnóstico histopatológico e diferentes experiências entre os profissionais da área (ERMERTCAN; HELLINGS; CINGI, 2012; GARCIA-ZUAZAGA; OLBRICHT, 2008).

\subsubsection{Indução do Carcinoma Espinocelular Cutâneo}

Os modelos experimentais do CEC em animais fornecem embasamentos para avaliar alterações morfológicas e moleculares que podem contribuir em investigações para novos tratamentos. Há diferentes métodos para indução do CEC em animais; no método físico, a radiação UV com uso de lâmpadas é usada durante determinado período de tempo na pele do animal, rapidamente surgem lesões, entretanto, a desvantagem deste tipo de indução é a severidade que a pele do animal sofre sem a formação de um carcinoma específico (DE LAAT; van der LEUN; DE GRUIJL, 1997). Outra forma de indução do CEC é o transplante de linhagens de células tumorais nos animais; que é um método rápido, mas possui a desvantagem na reprodução do microambiente tumoral, alguns dados são perdidos ou ineficientes, como o contato com tecidos normais adjacentes, vascularização angiolinfática e sistema imune (KHAVARI, 2006).

Outra via de indução do CEC é carcinogênese química que consiste em dois diferentes métodos: a carcinogênese completa ou por dois estágios. A carcinogênese completa refere-se à aplicação da dose única ou repetidas aplicações em doses menores de um agente denominado iniciador, que é responsável por causar alterações genéticas. O modelo de dois estágios tem mais de 60 anos de estudos e envolve o processo definido como iniciação e promoção. O agente iniciador é aplicado uma única vez para causar alterações no material genético e a outra substância atua como agente promotor, responsável por estimular a proliferação das células iniciadas. A carcinogênese de dois estágios é um modelo bem 
estabelecido para o estudo sequencial e gradual do desenvolvimento do CEC com a utilização de duas substâncias químicas, DMBA e TPA (ABEL et al., 2009; DIGIOVANNI, 1992).

O DMBA é um hidrocarboneto poliaromático, cujo mecanismo de ação é provocar alterações genéticas irreversíveis, na qual predispõe células normais à evolução maligna e imortalidade. Do ponto de vista fenotípico, as células permanecem similares às células normais e passam a sofrer mutações que induzem a proliferação celular, mas não há diferenciação nos estágios iniciais. Mesmo que os danos no DNA estejam bem estabelecidos, estes danos ainda poderão ser corrigidos pelos mecanismos de reparo do DNA. As células iniciadas podem permanecer latentes por semanas, meses ou anos, a expansão clonal destas células é resultado da atividade mitótica e da inibição da apoptose. A iniciação é um processo rápido e um fenômeno irreversível que pode ser passado para as células-filhas (DIGIOVANNI, 1992; OLIVEIRA et al., 2007).

O TPA é um derivado de sementes de cróton (Croton tiglium), pode ser denominado também como PMA (phorbol-12-myristate-13-acetate). A atividade mais importante dos promotores é durante a mitose, pois aumentam a proliferação celular em tecidos susceptíveis ao câncer. Os promotores são capazes de adiar a inibição de células quiescentes ou em GO, contribuem na fixação das mutações, aumentam as alterações na expressão gênica e causam mudanças no controle do crescimento celular. Por outro lado, os promotores podem provocar danos indiretamente ao DNA por oxidação. O promotor deve estar presente por semanas, meses, anos para ser efetivo e sua eficácia depende da sua concentração no tecido alvo. Promoção é um processo reversível, com o desuso do promotor, a proliferação celular decai, provavelmente por causa da apoptose (OLIVEIRA et al., 2007). O tratamento pelo TPA repetidamente na pele previamente tratada pelo DMBA promove a formação de tumores benignos que começam a surgir cerca de 6 a 12 semanas. Os agentes promotores estimulam o aumento na espessura epidermal, proliferação de queratinócitos basais, na síntese de DNA e células inflamatórias (ABEL et al., 2009).

Os primeiros tumores na pele que aparecem pelo método de dois estágios de carcinogênese são lesões pré-malignas denominadas papilomas. Os papilomas são considerados heterogêneos, pois seguem caminhos diferentes uns dos outros, poucos progridem para o CEC e boa parte regride (DIGIOVANNI, 1992). Papilomas gerados nesse modelo de carcinogênese podem progredir para o CEC em aproximadamente 20 semanas após iniciar o tratamento pelo agente promotor. A progressão para CEC depende de vários fatores como constituição genética utilizando linhagens de camundongos mais susceptíveis às drogas, dose do iniciador e promotor e tempo de indução (ABEL et al., 2009). A vantagem 
neste tipo de indução é a observação das mudanças no tecido e a identificação de lesões préneoplásicas, semelhantes às que ocorrem no desenvolvimento do $\mathrm{CEC}$ em humanos, a desvantagem é que o método de indução requer maior tempo (DIGIOVANNI, 1992; OLIVEIRA et al., 2007).

$\mathrm{Na}$ carcinogênese química, geralmente são utilizados camundongos por possuírem metabolismo alto, estes animais desenvolvem na maioria dos casos, lesões pré-neoplásicas que possuem similaridades histopatológicas com as lesões dos humanos (BALMAIN; HARRIS, 2000). As similaridades ocorrem também no nível genético e molecular, incluindo mutações nos membros da família Ras, ativação do receptor do fator de crescimento epidermal (EGFR), ativação das vias de sinalização envolvendo Stat3 e Akt, elevada expressão do fator de crescimento transformador $\beta 1$ (TGF- $\beta 1$ ) e mutação no gene p53 (ABEL et al., 2009).

\subsubsection{Genes Alvos no Desenvolvimento do Carcinoma Espinocelular Cutâneo}

Há duas classes de genes que podem levar as células à carcinogênese, são os oncogenes e os genes supressores de tumor. Genes que atuam como sinalizadores na progressão da célula para a divisão celular são denominados proto-oncogenes, estes genes mediante alguma mutação podem levar ao crescimento celular descontrolado e passam a ser denominados oncogenes. Uma mutação ou alteração na expressão em apenas um alelo de proto-oncogenes é o suficiente para induzir ao fenótipo neoplásico, pois estes genes têm como característica genética o traço dominante. Os genes supressores de tumor possuem o traço recessivo, isto indica perda da função nos dois alelos para que ocorra a mudança fenotípica. Os genes supressores de tumor regulam de forma negativa o crescimento celular, pois atuam no controle e na parada do ciclo celular quando há necessidade de reparo ao DNA, quando a célula não consegue reparar, alguns destes genes supressores podem direcionar a célula para apoptose. A maioria dos cânceres surge por mutações que ativam os oncogenes ou inativam os genes supressores de tumor (MICHOR; IWASA; NOWAK, 2004). Os principais alvos no desenvolvimento do CEC estão relacionados com mutações no oncogene Ras (10 a 30\% incidências) e no gene supressor de tumor p53 (40 a 50\% de incidências) (ABEL et al., 2009; BUKHARI et al., 2009).

A família Ras compreende os genes: H-ras (Harvey), k-ras (Kirsten) e N-ras, os quais são cruciais em muitas vias de sinalização, incluindo a progressão das células no ciclo celular, crescimento, migração, mudanças no citoesqueleto, senescência e apoptose (FERNÁNDEZ- 
MEDARDE; SANTOS, 2011). Mutações no gene H-ras ocorrem em modelos experimentais de carcinogênese química em camundongos, estas mutações podem ser detectadas na epiderme 3 a 4 semanas após tratamento pelo DMBA e ocorrem na maioria dos papilomas após aplicações pelo TPA. O DMBA causa mutação no códon 61 e ocorre a substituição da base adenina por timina (ABEL et al., 2009; BOUKAMP, 2005; DIGIOVANNI, 1992; DLUGOSZ; MERLINO; YUSPA, 2002).

Metade das neoplasias malignas conhecidas está associada à inativação do gene p53. Parte das mutações neste gene são trocas de bases entre citosina e timina, com alta frequência de trocas duplas entre citosina (CC) para timina (TT). O gene p53 é um supressor de tumor, pois, para o ciclo celular mediante danos ao DNA e direciona células danificadas para apoptose pela estimulação da produção de proteínas pró-apoptóticas. Em células sadias, p53 está presente em baixas concentrações, pois tem vida curta. Há estimativas de que 10 a 90\% do CEC apresentam mutações no gene p53, isto resulta na síntese de uma proteína mais estável do que a proteína selvagem, com acúmulo intracelular da proteína p53, isto confere positividade desta proteína à marcação imuno-histoquímica. A expressão imuno-histoquímica aberrante de p53 não está correlacionada com aumento no número de células apoptóticas em CECs, mas com o fato da proteína estar mutada (BATINAC et al., 2006; BOUKAMP, 2005; BUKHARI et al., 2009).

A proteína p53 selvagem age como o principal obstáculo no desenvolvimento da carcinogênese. Perante danos ao DNA, a concentração desta proteína aumenta no núcleo, pois o desacoplamento da p53 de suas reguladoras negativas, as proteínas Mdm2 ou Mdm4 responsáveis pela degradação de p53, leva ao acúmulo desta proteína ativa que não consegue ser degradada. Isto causa a parada do ciclo celular na fase G1 e permite um tempo maior para o reparo do DNA. Um dos genes regulados por p53 codifica a proteína p21, que ao se ligar aos complexos formados entre quinases dependentes de ciclinas (CDKs) e ciclinas durante o ciclo celular, inibe suas atividades impedindo a entrada da célula na fase $\mathrm{S}$. A proteína p21 se liga ao Antígeno Nuclear de Proliferação Celular (PCNA) causando o bloqueio da função de PCNA durante a replicação do DNA, impedindo a proliferação celular. Células que contém p53 mutante ou ausente são incapazes de manter o ciclo celular normal mediante algum dano ao DNA, pois faltará às células o reparo na fase $\mathrm{G} 1$ e na fase $\mathrm{S}$, células danificadas acumularão mutações em taxa crescente culminando com o desenvolvimento tumoral (MEEK, 2009; POLAGER; GINSBERG, 2009; TOLEDO; WAHL, 2006). 


\subsection{TERAPIA FOTODINÂMICA}

Tratamentos mediados por luz foram empregados na antiguidade por culturas egípcias, indianas e chinesas que usavam a luz solar para tratar uma variedade de doenças como vitiligo, psoríase e câncer (ACKROYD et al., 2001). Desde a descrição por Oscar Raab da morte celular em paramécio, a TFD é considerada um tratamento promissor contra várias doenças cutâneas e neoplasias. O princípio deste tratamento é uma interação entre luz no espectro visível, substância fotossensibilizadora e oxigênio endógeno que levam à toxicidade para as células alvo.

A TFD possui dois mecanismos de ação que podem ocorrer tanto separadamente como em conjunto (ARIAS et al., 2007; DOUGHERTY; GOMER; HENDERSON, 1998). O primeiro mecanismo é denominado como reação I, após a absorção de fótons pelo corante, os fótons entram em excitação eletrônica denominada tripleto, em seguida, ocorre transferência de elétrons do FS que pode atuar diretamente com os substratos biológicos para formar radicais livres ou ERO. Outro mecanismo da TFD é denominado como reação II, mais comum, na qual consiste em transferência da energia do FS diretamente para o oxigênio molecular dissolvido nas células para formar o ${ }^{1} \mathrm{O}_{2}$, que é um estado eletronicamente excitado do oxigênio (KUBLER, 2005; MACHADO, 2000; MROZ et al., 2011). As reações I e II da TFD estão representadas na Figura 1.

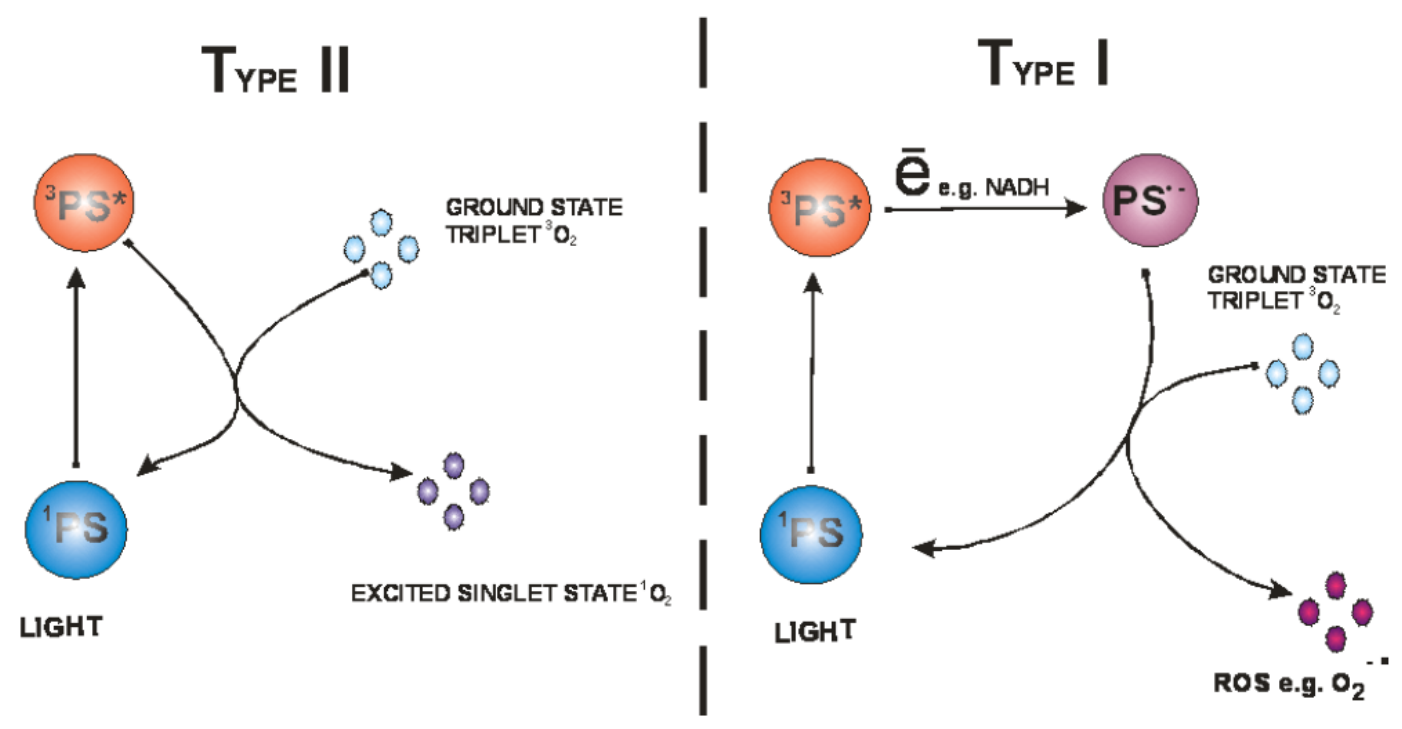

Figura 1 - Mecanismos de ação da TFD, reação tipo I e II. Fonte: (MROZ et al., 2011) 
$\mathrm{O}^{1} \mathrm{O}_{2}$ é uma ERO, possui tempo de vida curto (cerca de $2 \mu \mathrm{s}$ ) e os sítios metabólicos são indefinidos, ou seja, esta molécula pode interagir com qualquer alvo na célula como lipídios de membrana, aminoácidos, proteínas, ácidos nucleicos, carboidratos e tióis. O tempo de vida curto do ${ }^{1} \mathrm{O}_{2}$ favorece a reatividade desta molécula no alvo tecidual doente sem distribuição para sítios vizinhos sadios (JUARRANZ et al., 2008).

A TFD possui vantagens de apresentar baixa toxicidade para os pacientes, o tratamento não é invasivo, proporciona diminuição dos efeitos colaterais e demanda menor custo operacional, pois pode ser realizada em ambiente ambulatorial sem necessidade de internações. Além disso, a TFD pode ser aplicada sozinha ou combinada com outros tratamentos para câncer, como quimioterapia, cirurgia, radioterapia ou imunoterapia (ARIAS et al., 2007; MACHADO, 2000).

O tratamento pela TFD auxilia na destruição de tumores residuais prevenindo a recorrência do tumor na região e quando combinada com cirurgia ou quimioterapia previne metástases. Esta terapia pode ser usada em pessoas mais velhas ou pacientes debilitados por causa dos outros tratamentos, pois o risco de reações adversas é baixo. Os problemas relatados pelos pacientes com relação à TFD se referem à sensação de ardência na pele restrita a área irradiada, erosões e crostas, eritema e edema, alguns relatam dor e há casos de hiper ou hipopigmentação, entretanto, a maioria das reações causadas nos pacientes desaparece alguns dias ou meses após tratamento e essas reações geralmente são bem toleradas pelos pacientes (BAPTISTA et al., 2006; CALZAVARA-PINTON et al., 2008; ORRINGER et al., 2008).

As fontes de luz utilizadas na TFD incluem lâmpadas convencionais (halógenas, xênon), lasers e LEDs. O barateamento de lasers gerou maior uso deste tipo de luz e a alta potência contribuiu com a redução do tempo de irradiação quando comparado a lâmpadas convencionais. Outro importante uso do laser é o acoplamento de fibras ópticas para alcançar órgãos internos (KUBLER, 2005; MANG, 2004).

Além de variadas fontes de iluminação, há vários tipos de FSs usados na TFD, como porfirinas, clorinas, ftalocianinas e fenotiazínicos. Na TFD, um FS adequado deve ser: quimicamente puro, estável, ter boa absorção pelo tecido alvo, apresentar baixa toxicidade na ausência da luz, apresentar alta produção de ${ }^{1} \mathrm{O}_{2}$ e possuir coeficiente elevado de absortividade molar, especialmente na parte vermelha do espectro visível (>630 nm), o qual os tecidos humanos transmitem luz mais eficientemente. Portanto, os FSs precisam ter forte absorção de luz nesta região do espectro para alcançar a janela terapêutica (600 a $800 \mathrm{~nm}$ ), ou seja, ter efeito fotodinâmico. Quanto maior o comprimento de onda, maior será a penetração da luz no tecido. A profundidade da luz alcança cerca de $4 \mathrm{~mm}$ no tecido entre 500 a $600 \mathrm{~nm}$ e 
pode atingir até $8 \mathrm{~mm}$ entre 600 a $800 \mathrm{~nm}$ (JUARRANZ et al., 2008; KUBLER, 2005; ORMOND; FREEMAN, 2013).

A primeira geração de FSs foram os derivados de hematoporfirinas, como Photofrin ${ }^{\circledR}$ (Pinnacle Biologics, Bannockburn, Illinois, USA), Photogem ${ }^{\circledR}$ (TimTec LLC, Newark, New Jersey, USA) que quando injetados na corrente sanguínea acumulavam dentro do organismo provocando fotossensibilidade, inúmeras pesquisas foram feitas para criar outros FSs com diminuição deste efeito (CASTANO; DEMIDOVA; HAMBLIN, 2005; DOUGHERTY; GOMER; HENDERSON, 1998). A segunda geração de FSs teve como objetivo ter moléculas que penetraram mais profundamente e apresentaram eliminação mais rápida do tecido, são exemplos de derivados de hematoporfirinas, o meta-tetra(hydroxyphenyl)porphyrin (mTHPP), ácido 5-aminolevulínico (ALA); Methyl aminolevulinate (MAL) (ORMOND; FREEMAN, 2013).

A TFD é eficiente contra neoplasias porque pode causar morte celular por apoptose, necrose e há estudos relacionados à autofagia, pode ativar o sistema imune contra as células tumorais ou destruir a vascularização dos tumores (Figura 2) (CASTANO; DEMIDOVA; HAMBLIN, 2004; MROZ et al., 2011). A localização do FS dentro do compartimento celular indica como a célula morreu, o acúmulo do FS na mitocôndria ou no retículo endoplasmático aponta que a morte celular ocorreu pela via apoptótica. Contudo, a localização do FS no Complexo de Golgi, lisossomo, membrana plasmática ou citosol indica que a morte celular ocorreu por necrose (CASTANO; DEMIDOVA; HAMBLIN, 2004; JUARRANZ et al., 2008).

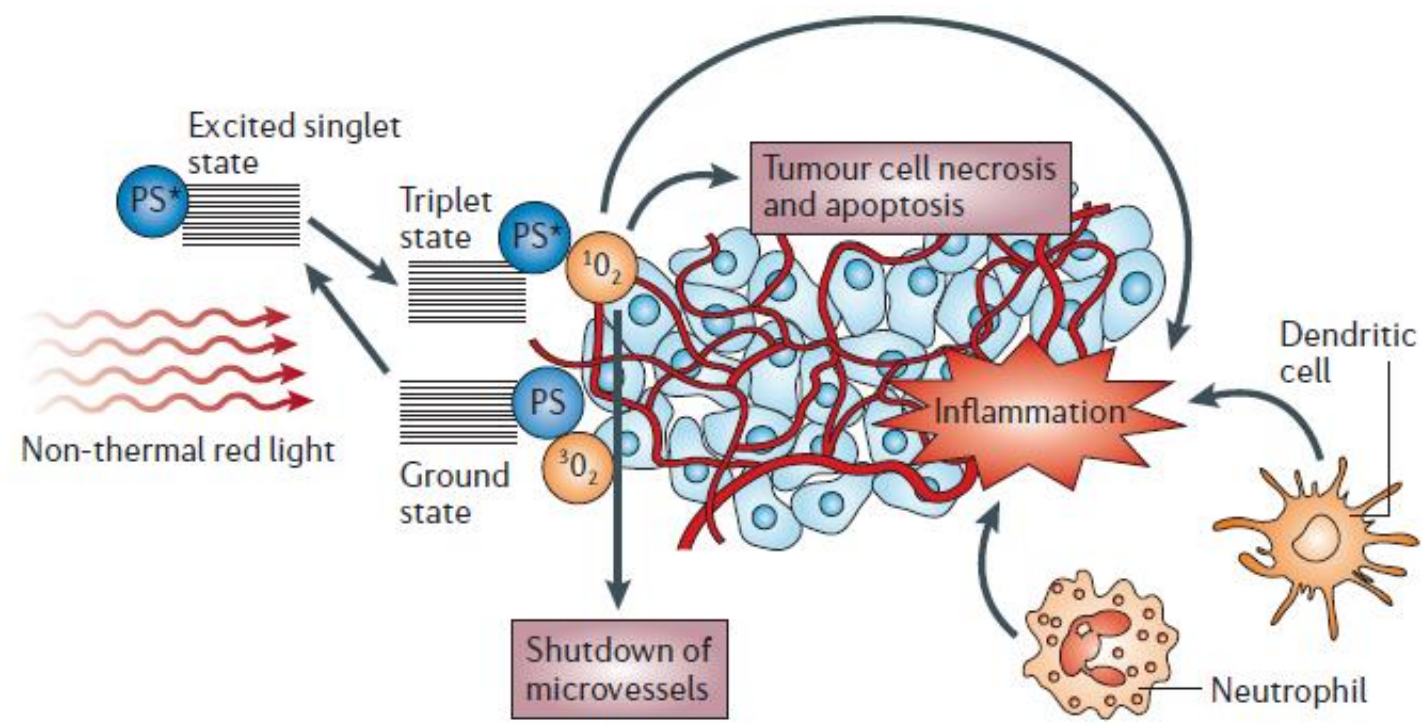

Figura 2 - Principais mecanismos de morte celular causados pela Terapia Fotodinâmica. Fonte: (CASTANO; MROZ; HAMBLIN, 2006). 


\subsubsection{Terapia Fotodinâmica mediada por Azul de Metileno}

O AM é um corante do tipo fenotiazínico, não é um derivado de hematoporfirina, foi sintetizado pela primeira vez em 1876 e introduzido na área de microbiologia por Robert Koch e Paul Ehrlich para estudos em micro-organismos que causavam doenças. O AM é um cátion que pode intercalar no DNA por causa de sua carga positiva. Portanto, sua atividade se torna baixa, pois o AM sofre redução pelos sistemas biológicos, isto evita que o DNA sofra danos causados por este FS. O AM tem preferência pela mitocôndria, sua carga positiva atrai esta molécula para o ambiente mitocondrial que possui matriz eletricamente negativa e sua relativa lipofilicidade permite a permeação em membranas (BAPTISTA et al., 2006).

O AM é um composto hidrofílico, possui absorção rápida nas células tumorais, é rapidamente descartado do tecido alvo, evitando acúmulo e possivelmente fotossensibilidade ao paciente (WAINWRIGHT, 2005). Uma grande vantagem deste FS é que ele absorve luz dentro da janela terapêutica $(600$ a $800 \mathrm{~nm})$ na qual há maior penetração da luz no tecido. A solução do AM em determinadas concentrações pode formar dímeros (máximo de absorbância em $590 \mathrm{~nm}$ ), o que diminui a formação do ${ }^{1} \mathrm{O}_{2}$. Para que o AM alcance o espectro desejado, a solução deve atingir a forma de monômeros com o máximo de absorbância em 664 nm, como observado na Figura 3 (SEVERINO et al., 2003; WAINWRIGHT, 2005).

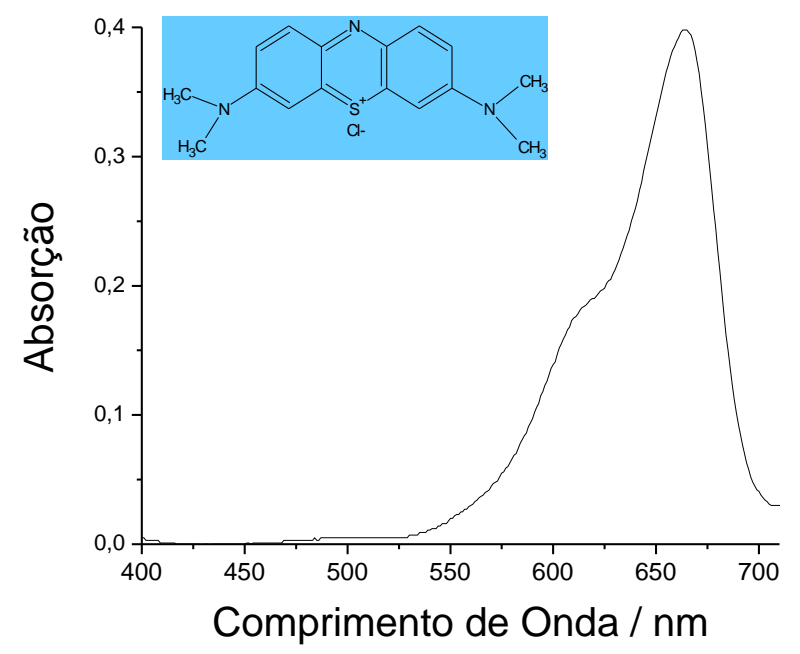

Figura 3 - Espectro de absorção do azul de metileno em meio aquoso. Fonte: (SEVERINO et al., 2003)

Orth et al. (1998) estudaram o tratamento pela TFD em tumores de cólon transplantados em camundongos com uso do AM e outros agentes fotossensibilizadores como 
Photosan-3, Zn-ftalocianina e Al-ftalocianina. Após um único tratamento pela TFD mediada por AM na dose total de energia $100 \mathrm{~J} / \mathrm{cm}^{2}$ provocou a destruição de $75 \%$ dos tumores. A toxicidade do AM foi mais intensa do que os outros agentes fotossensibilizadores analisados. Menezes et al. (2007) avaliaram o uso de diferentes FSs na aplicação da TFD em linhagem de células tumorais HEp-2 e em duas linhagens de células não tumorais VERO e McCoy. Linhagens de levedura também foram analisadas. Os FSs utilizados foram o AM, a eritrosina, a fluoresceína e o Photogem ${ }^{\circledR}$. As células foram irradiadas por LED a $630 \mathrm{~nm}$, potência de 15 $\mathrm{mW} / \mathrm{cm}^{2}$ por 20 minutos. Photogem ${ }^{\circledR}$ e AM apresentaram bandas na faixa de 630 a $667 \mathrm{~nm}$ na luz vermelha ocasionando a inativação de células e micro-organismos. Esse resultado mostrou a eficácia do AM que é mais barato quando comparado aos outros FSs.

Um relato de caso para sarcoma de kaposi em paciente HIV (vírus da imunodeficiência humana) positivo que não havia respondido à quimioterapia foi tratado pela TFD-AM com fonte de luz RL50 ${ }^{\circledR}$ na dose total de $18 \mathrm{~J} / \mathrm{cm}^{2}$, com várias sessões da TFD. O tratamento mostrou eficácia na formação de novo tecido na área tratada e as biópsias após tratamento foram negativas ao câncer (TARDIVO et al., 2006).

O papel da TFD mediada por AM na cicatrização de feridas foi pesquisado na pele de ratos, os resultados obtidos foram comparados ao tratamento por terapia com laser sozinho. Uma única aplicação da TFD influenciou o processo de cicatrização, portanto, os autores não indicaram uma melhora neste processo em relação à terapia aplicada apenas com laser, o fechamento da lesão ocorreu em 14 dias nos dois tratamentos aplicados. Contudo, este estudo evidenciou que a TFD-AM pode ser usada no tratamento para cicatrização de feridas, já que não atrasa o fechamento da ferida e promove um efeito antimicrobiano que justifica o seu uso (SPERANDIO et al., 2010).

Tardivo et al. (2005) apresentaram diversas áreas clínicas para o uso da TFD-AM, como no tratamento do CBC em uma área da orelha que se fosse tratada cirurgicamente poderia provocar mutilação ou a cirurgia associada a radioterapia poderia causar algum dano neurológico. Outra aplicação da TFD apresentada neste trabalho foi para micoses na unha que apresentaram resultados satisfatórios. O tipo de luz usada foi RL50 ${ }^{\circledR}$, as dosagens totais da TFD-AM variaram entre 18 a $36 \mathrm{~J} / \mathrm{cm}^{2}$. Todos os casos foram acompanhados por algum tempo e apresentaram boas perspectivas relacionadas ao tratamento. 


\subsection{EFEITOS BIOLÓGICOS APÓS TERAPIA FOTODINÂMICA}

Há várias pesquisas que mostraram resultados variados em relação às respostas obtidas após TFD. Essas variações nas respostas se referem ao tipo de FS, tipo de luz, dosagem destes componentes, número de sessões da TFD e o tipo de tecido alvo. Os efeitos macroscópicos relacionados à TFD consistem na avaliação do tamanho e morfologia tumoral; ao passo que, os efeitos microscópicos após TFD incluem avaliação histopatológica e efeitos no microambiente tumoral, regulação do ciclo celular e morte celular, análise do sistema imune e danos na vascularização do tumor (ALMEIDA et al., 2004; ROBERTSON; EVANS; ABRAHAMSE, 2009).

\subsubsection{Efeitos macroscópicos}

Há bons indícios de redução tumoral após TFD em tumores transplantados em animais com aplicação de variados tipos de FSs. Takahashi et al. (2004) relataram a diminuição do volume tumoral em CEC transplantados na pele de camundongos após TFD mediada pela aplicação tópica de uma pomada com ATX-S10 (Na) e irradiada com laser diodo na dose de $150 \mathrm{~J} / \mathrm{cm}^{2}$. Os tumores apresentaram necrose e foram eliminados completamente após 6 semanas seguidas de tratamento. Em células RK3E-ras injetadas em rato e irradiadas com laser diodo, na dose total $100 \mathrm{~J} / \mathrm{cm}^{2}$, uma única sessão da TFD mediada por injeção intravenosa de clorina $\mathrm{e}_{6}\left(\mathrm{Ce}_{6}\right)$ parou a progressão tumoral. As imagens da anatomia do tumor, raios-X e bioluminescência mostraram que o tumor desapareceu quase por completo (MOON et al., 2009).

$\mathrm{Na}$ aplicação tópica de aluminum phthalocyanine chloride (AlClPc) associado ao laser diodo, comprimento de onda $670 \mathrm{~nm}$, a TFD foi aplicada na pele de camundongos com melanoma. Neste estudo foram usados sete parâmetros relacionados à densidade de potência e dose de energia total. O volume tumoral foi acompanhado por 14 dias. Em três sessões de TFD, a maioria dos grupos não apresentou remissão total dos tumores, apenas um dos grupos obteve $60 \%$ de remissão na primeira aplicação com densidade de potência de $75 \mathrm{~mW} / \mathrm{cm}^{2}$, dose total de $150 \mathrm{~J} / \mathrm{cm}^{2}$. Todos os animais tratados com a densidade de potência de 100 $\mathrm{mW} / \mathrm{cm}^{2}$ tiveram alta mortalidade durante o tratamento (KYRIAZI et al., 2008).

O AM tem mostrado eficácia na redução tumoral em algumas pesquisas utilizando modelos animais. A linhagem de células melanomas B16F1 foram transplantadas em camundongos e tratadas pela TFD-AM por 3 semanas, utilizando densidade de potência 50 
$\mathrm{mW} / \mathrm{cm}^{2}$ e dose total de $100 \mathrm{~J} / \mathrm{cm}^{2}$. O tamanho dos tumores diminuiu em $65,1 \%$ na terceira semana e os animas tratados tiveram os dias de sobrevivência prolongados quando comparados ao controle (CHEN et al., 2008). Outra redução tumoral (em 99\%) foi relatada pelo uso do AM em melanomas transplantados em camundongos que foram irradiados por fonte de luz RL50 ${ }^{\circledR}$ na dose total de $30 \mathrm{~J} / \mathrm{cm}^{2}$ (WAGNER et al., 2012).

\subsubsection{Efeitos na histopatologia tumoral e no colágeno tipo I}

A TFD pode contribuir na melhora da morfologia tecidual em variados tipos de lesões, cinquenta e cinco biópsias de pele com CBC e doença de Bowen foram obtidas de 28 pacientes após duas aplicações pela TFD mediada por MAL (TFD-MAL), as lesões foram irradiadas com LED, comprimento de onda de $630 \mathrm{~nm}$, potência $50 \mathrm{~mW} / \mathrm{cm}^{2}$ e dose total de 37 $\mathrm{J} / \mathrm{cm}^{2}$ As amostras analisadas foram obtidas 1 a 2 horas e 1 a 2 dias após TFD. Os resultados mostraram difuso dano epidermal apresentando edema, vacuolização de queratinócitos tanto no $\mathrm{CBC}$ como na doença de Bowen, 15 minutos após a TFD. A derme profunda e média apresentou inflamação aguda com edema, vasodilatação, células sanguíneas extravasadas, infiltrado inflamatório intersticial e perivascular difuso consistindo de células polimorfonucleares (neutrófilos e eosinófilos) e mononuclear (linfócitos, monócitos e plasmócitos). Ao $7^{\circ}$ dia, a epiderme foi regenerada em ambos os carcinomas e a derme mostrou nova formação de colágeno e persistência do infiltrado mononuclear (FANTINI et al., 2008).

No modelo experimental de queimadura de terceiro grau em ratos, a TFD foi aplicada com azul de toluidina e laser, comprimento de onda $685 \mathrm{~nm}$, potência de $0,5 \mathrm{~W} / \mathrm{cm}^{2}$, dose total de 4,5 $\mathrm{J} / \mathrm{cm}^{2}$. Os animais foram sacrificados 3,7 e 14 dias após a cirurgia. No $3^{\circ}$ dia, na maioria dos grupos, sinais de inflamação foram discretos no tecido com moderada quantia de fibras colágenas, reepitelização e intensa angiogênese. No $14^{\circ}$ dia, células representativas de inflamação aguda e crônica foram vistas no tecido. Reepitelização foi evidente quase cobrindo a lesão com espessura irregular da epiderme e a derme apresentou vasos sanguíneos recémformados e grande número de fibras colágenas. Esses dados foram comparados à aplicação do laser de baixa intensidade com poucas diferenças entre os dois tratamentos, entretanto, a TFD indicou melhor tendência para a cicatrização (GARCIA et al., 2010).

Pacientes com queratose actínica receberam três sessões consecutivas da TFD-MAL com LED, dose total $37 \mathrm{~J} / \mathrm{cm}^{2}$. Biópsias três meses antes e depois da última sessão foram retiradas da pele sadia e da área de cancerização, termo utilizado para definir a pele 
fotodanificada cronicamente e que apresenta lesões pré-malignas ou câncer de pele. A taxa de eliminação da queratose actínica após tratamento foi de $89,5 \%$ e apresentou excelente resultado cosmético, diminuição na atipia celular e aumento no depósito de colágeno (SZEIMIES et al., 2012).

No modelo experimental em camundongos para queratose actínica, a TFD foi testada utilizando dois FSs, hypericin (HY) e MAL. O protocolo usado na TFD foi irradiação por Omnilux $P D T^{\circledR}$ lamp, densidade de potência $20 \mathrm{~mW} / \mathrm{cm}^{2}$ e dose total $40 \mathrm{~J} / \mathrm{cm}^{2}$. A TFD mediada por HY foi menos eficiente do que por MAL, HY apresentou acúmulo no estrato córneo da epiderme, ao passo que, MAL apresentou distribuição mais uniforme pelo tecido. A análise histopatológica mostrou que após 24 horas da TFD-HY algumas lesões apresentaram necrose confinada somente na região superficial do tumor, enquanto a TFD-MAL as lesões apresentaram necrose acentuada pelos demais estratos da epiderme e derme. A falta de distribuição uniforme pelo HY impediu que a TFD respondesse de forma eficaz no tratamento da queratose actínica (BOIY; ROELANDTS; DE WITTE, 2011).

O aumento no depósito de colágeno tipo I foi relatado na pele fotodanificada e pele com queratose actínica em pacientes tratados com três consecutivas sessões da TFD mediada por MAL, irradiação com luz vermelha na dose total de $37 \mathrm{~J} / \mathrm{cm}^{2}$ (CHOI et al., 2010). Ocorreu aumento na expressão gênica do pró-colágeno tipo I e III após TFD-ALA na pele fotodanificada em pacientes com idade entre 54 a 83 anos, a iluminação foi realizada com laser de corante pulsado na fluência de $7,5 \mathrm{~J} / \mathrm{cm}^{2}$, o aumento do colágeno foi relacionado com a melhora na aparência da pele após tratamento (ORRINGER et al., 2008). Na pele sadia de camundongos, o aumento na expressão do colágeno tipo I iniciou 12 dias após o tratamento da TFD mediada por ALA com uso de LED, comprimento de onda $635 \mathrm{~nm}$, dose total de 25 $\mathrm{J} / \mathrm{cm}^{2}$ (SZEIMIES et al., 2012).

\subsubsection{Efeitos na regulação do ciclo celular e apoptose}

O câncer está diretamente ligado às desordens no ciclo celular que é um processo que envolve fases distintas: interfase e mitose. A interfase é mais demorada do que a fase M, pois é subdividida em três fases, fases G1, S e G2. Na fase G1, ocorre síntese de RNA e de proteínas que recuperam o volume celular anteriormente reduzido na mitose; na fase $\mathrm{S}$, ocorre duplicação do material genético e na fase G2, as células acumulam energia para ser usada durante a mitose e sintetizam tubulina para formar os microtúbulos do fuso mitótico. Na fase M, ocorre a divisão de todos os componentes celulares em duas células idênticas. As células 
que saem do ciclo celular e não se renovam ficam em estado de repouso denominado fase G0 (GABRIEL, 2007).

Os pontos de checagem nas células que ocorrem durante as fases finais do G1 e G2 servem para as células completarem a replicação ou para reparar danos antes da progressão do ciclo para a entrada na mitose. Se os pontos de checagem são ignorados, a progressão do ciclo celular pode resultar em danos genômicos irreparáveis com a propagação de mutações (CLARKE; ALLAN, 2009). As principais proteínas que controlam o ciclo celular são as ciclinas, que são subunidades reguladoras e as CDKs que são subunidades catalíticas. A união entre CDKs e ciclinas forma um complexo denominado CDKs-ciclinas, mediante problemas com o ciclo celular, a ativação deste complexo não é completada (GABRIEL, 2007).

A homeostase tecidual envolve equilíbrio entre a proliferação celular e a morte celular. Uma das proteínas importantes durante o ciclo celular e nos mecanismos de reparo do DNA é a proteína PCNA que interage com várias proteínas nas células dos eucariotos; o PCNA se liga aos complexos CDKs-ciclinas que são formados durante o ciclo celular e são cruciais para que ocorra a divisão celular e se liga também aos inibidores do ciclo celular como p21. O principal papel do PCNA é na fase $\mathrm{S}$ na forquilha de replicação, pois pode parar a síntese do DNA em locais onde haja danos (MAGA; HUBSCHER, 2003; MOLDOVAN; PFANDER; JENTSCH, 2007).

Em linhagens de células melanoma B16F10 transplantadas em camundongos e tratadas pela TFD-AM, foi verificado uma diminuição em $76 \%$ na expressão deste antígeno nos grupos tratados comparados ao controle (WAGNER et al., 2012). No estudo cinético da TFD realizada por Barcessat et al. (2013) o índice de células marcadas pelo PCNA diminuiu 48 horas após TFD-ALA e aumentou após 72 horas do tratamento em lesões orais potencialmente malignas. Neste mesmo estudo, o índice de PCNA aumentou após segunda sessão da TFD, esse aumento foi relacionado com a função reparadora de PCNA. A avaliação deste antígeno após tratamento contra o câncer é bom indicativo das respostas relacionadas à proliferação celular e mecanismos de reparo.

A sublocalização intracelular do FS indica qual o mecanismo de morte celular associado ao tratamento (BUYTAERT; DEWAELE; AGOSTINIS, 2007). O AM apresenta uma relativa lipofilicidade e facilmente atravessa a membrana plasmática e se liga na mitocôndria conduzindo a morte das células tumorais pela via intrínseca da apoptose com liberação do citocromo c (cyt c) e ativação da caspase 3 (LU et al., 2008). A caspase 3 clivada é um biomarcador de morte celular por apoptose, assim como, a utilização da técnica de TUNEL (terminal deoxynucleotidyl transferase-mediated dUTP nick end-labeling) que 
identifica in situ a fragmentação do DNA. Desta forma, a incorporação de nucleotídeos marcados nos sítios de fragmentação do genoma pela ação da enzima terminal deoxinucleotidil transferase (TdT) são identificados nessa técnica pela reação da peroxidase com a 3,3-Diaminobenzidina (DAB) (KRYSKO et al., 2008).

A via intrínseca da apoptose é ativada por vários estímulos, como danos ao DNA e insultos citotóxicos que são produzidos pela TFD, a ativação desta via ocorre pela interação com a mitocôndria, organela regulada por proteínas localizadas na membrana externa mitocondrial que são membros da família Bcl-2. Os genes da família Bcl-2 representam uma das mais relevantes classes biológicas na regulação da apoptose. Em condições de homeostase, membros antiapoptoticos antagonizam os membros pró-apoptóticos da família Bcl-2 para manter a integridade mitocondrial. Os membros pró-apoptóticos da família Bcl-2 compreendem as proteínas Bax, Bak, Bok, Bid, Bim, Bik, Bad, Bmf, Kek, Noxa e Puma. Já os membros antiapoptoticos se referem às proteínas Bcl-2, Bcl-xL, A1, Bcl-w e Mcl-1, A1/Bfl1. A homologia entre essas proteínas compreende 4 domínios $\mathrm{BH}$ (BH1, BH2, BH3, BH4), algumas proteínas pró-apoptóticas possuem apenas o domínio BH3 (CORY; ADAMS, 2002).

Quando a inibição dos membros pró-apoptóticos é diminuída, sucede a oligomerização das proteínas pró-apoptóticas, em especial Bax e Bak, com subsequente abertura de canais na membrana mitocondrial permitindo a passagem do cyt c e outras proteínas mitocondriais para o citosol. O cyt c liberado no citosol se associa com APAF-1, ATP e procaspase 9 formando uma plataforma proteica denominada apoptossomo. A caspase 9 cliva e ativa as caspases executoras 3, 6 e 7 que são essenciais para a efetivação da apoptose (DUPREZ et al., 2009; YOULE; STRASSER, 2008). A via intrínseca da apoptose está representada na Figura 4. A TFD mediada por Pc 13 em linhagem do carcinoma de nasofaringe em humanos induziu apoptose pela liberação de proteases dos lisossomos que permeabilizaram a membrana mitocondrial, ocorreu inibição das proteínas antiapoptóticas e ativação dos membros próapoptóticos, processo que finalizou com a ativação da caspase 3 (MARINO et al., 2013). 


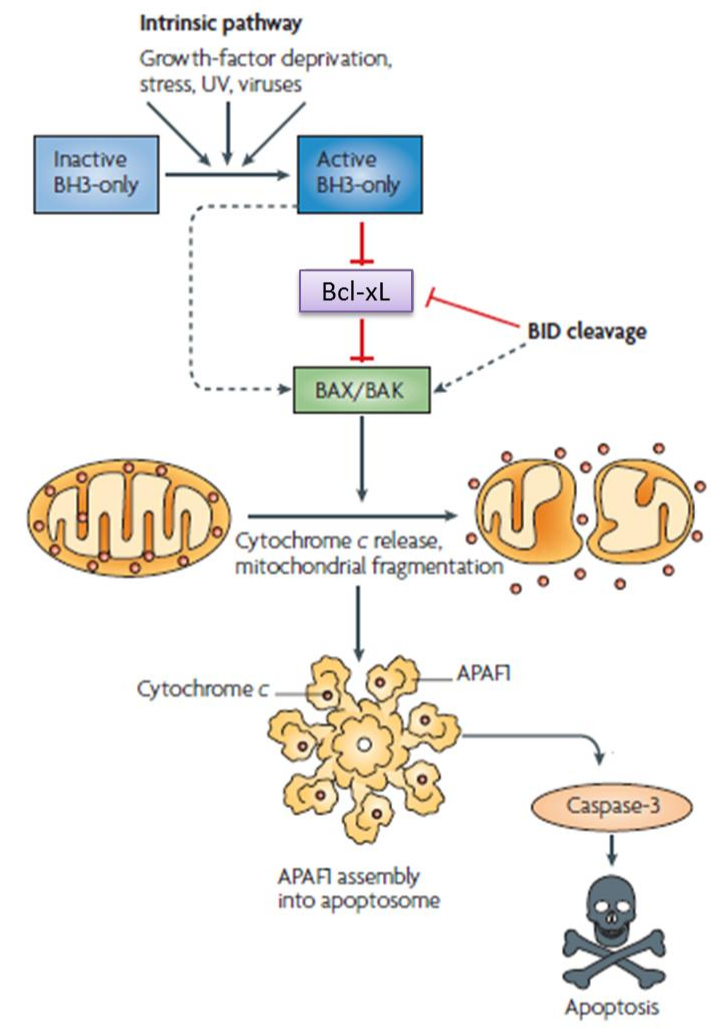

Figura 4 - Via intrínseca da apoptose. A via intrínseca começa com a ativação da proteína BH3 ou ativação póstraducional de alguns membros da Bcl-2. Isto alivia a inibição de Bax e Bak, que por sua vez promovem a apoptose. Uma vez ativado Bax e Bak promovem a liberação do cyt c e leva a ativação de APAF-1 que se reúne no apoptossomo que ativa a caspase 9 e depois ativa a caspase 3.

Fonte: Modificado de (YOULE; STRASSER, 2008)

A superexpressão de Bcl-xL, membro antiapoptotico da família Bcl-2, está correlacionada com a progressão do tumor para malignidade e metástase. Isto pode causar resistência às drogas quimioterápicas e radiação (ZHANG; BOWDEN, 2007). Um estudo indicou que além da função antiapoptótica de $\mathrm{Bcl}-\mathrm{xL}$ na região mitocondrial, esta proteína pode se localizar no núcleo e se ligar a CDK1 e assim estabilizar um ponto de checagem na fase G2/M do ciclo celular após danos ao DNA (SCHMITT; BEAUCHEMIN; BERTRAND, 2007). Bcl-xL foi apontado como um possível biomarcador para distinguir queratoacantoma e CEC na pesquisa de biópsias de pacientes diagnosticados como CEC durante o período de 1979 a 2005. Neste estudo foram incluídos 98 pacientes com média de idade de 70 anos, biópsias destes pacientes passaram por reavaliação histopatológica por dois especialistas, desta quantidade amostral, 27 foram confirmadas como CEC e 71 como queratoacantoma. Pela técnica tissue microarray vários marcadores foram avaliados e $\mathrm{Bcl}-\mathrm{xL}$ foi fortemente marcado no CEC e apresentou marcação negativa na maioria das lesões consideradas como queratoacantoma (VASILJEVIĆ et al., 2009). Embora tenha havido esta diferença na 
marcação, a combinação de Bcl-xL com outros marcadores, em adição a avaliação histopatológica são critérios necessários para diferenciar as duas lesões.

No estudo de Xue et al. (2003) múltiplas isoformas de Bcl-xL foram identificadas utilizando vários anticorpos que reconheceram especificamente este antígeno, os autores não sabem se as isoformas são mudanças pós-transcricionais da proteína. A TFD mediada por Pc 4 induziu fotodano em todas as isoformas relacionadas a proteína $\mathrm{Bcl}-\mathrm{xL}$, exceto na isoformas que apresentou o tamanho de 33 kDa em várias linhagens de câncer humano.

A expressão de Bak foi analisada em 24 pacientes ou com recorrência ou persistência do carcinoma de nasofaringe após tratamento por radioterapia. Esses pacientes foram submetidos ao tratamento pela TFD com derivado de hematoporfirina PSD007 e laser pulsado de vapor de cobre, comprimento de onda $630 \mathrm{~nm}$. Dentre os pacientes, 79\% apresentaram positividade à Bak antes da TFD. Portanto, 75\% apresentaram aumento na expressão desta proteína após tratamento, promovendo a apoptose nessas células (LAI et al., 2001). No estudo com duas linhagens de células, uma primária com queratinócitos normais e a linhagem HT1080 tratadas com UVB apresentaram aumento na expressão da proteína Bak, quando Bak foi eliminada por um inibidor, a apoptose foi diminuída nas células irradiadas (JACKSON et al., 2000).

Outra proteína importante na regulação da apoptose é a p53 que quando ativa pode induzir a transcrição de inibidores do ciclo celular ou de proteínas pró-apoptóticas. A regulação da apoptose realizada por p53 pode translocar esta proteína para a mitocôndria, onde ocorre interação com Bax e induz a liberação do cyt c e ativa a cascata de caspases (CLARKE; ALLAN, 2009).

\subsubsection{Efeitos no sistema imune}

O ideal para uma terapia contra o câncer é destruir o tumor primário e induzir o sistema imune reconhecer e localizar células tumorais remanescentes. Os mecanismos exatos da resposta imune antitumoral são desconhecidos, portanto há tentativas de utilizá-la no tratamento do câncer. Ao contrário dos tratamentos como cirurgia, quimioterapia e radioterapia que causam imunossupressão, os efeitos mediados pela TFD podem estimular a resposta inflamatória e do sistema imune. A TFD pode induzir uma resposta inflamatória aguda na área tratada, na qual rapidamente causa o recrutamento de células dendríticas, neutrófilos, mastócitos e monócitos/macrófagos. Estas células podem liberar mediadores 
inflamatórios para recrutar linfócitos T CD4, T CD8 e CD68 (macrófagos) no local tratado pela TFD (CASTANO; MROZ; HAMBLIN, 2006; NOWIS et al., 2005).

A resposta imunológica ocorre quando um antígeno entra em contato com células apresentadoras de antígenos (APC) que capturam uma parte do antígeno e o expõe para os linfócitos T auxiliares CD4. Desta forma, as células T CD4 são ativadas e promovem a ativação de outros linfócitos como o B ou T CD8 citotóxicos. Os linfócitos T CD8 ativados proliferam e executam a inativação ou eliminação do antígeno por morte celular ou pela secreção de citocinas reguladoras. As células T só reconhecem antígenos ligados às moléculas do complexo principal de histocompatibilidade (MHC) sobre a superfície de outras células. As moléculas do MHC da classe I são reconhecidas pelos linfócitos CD8, ao passo que, as moléculas MHC da classe II são expressas por macrófagos e são apresentadas aos linfócitos CD4 (CASTANO; MROZ; HAMBLIN, 2006; CHAUDHURI et al., 2009).

A morte celular por necrose pode potencializar a imunidade pela atração de leucócitos hospedeiros dentro do tumor e aumentar a apresentação de antígenos (NOWIS et al., 2005). Gollnick; Owczarczak, Maier (2006) verificaram que a TFD aumentou a capacidade das células APCs em nódulos linfáticos retirados de camundongos que receberam transplante de células tumorais EMT6 ou Colon 26 e foram tratados com TFD- Photofrin ${ }^{\circledR}$. O aumento na ativação de APCs melhorou o estímulo na proliferação de células T. No desenvolvimento do câncer, todos os componentes efetores do sistema imune tem potencialidade para contribuir na erradicação de células tumorais. Entretanto, a principal resposta imunológica celular contra a progressão tumoral se refere aos linfócitos T CD8, pois quando ativados podem destruir diretamente as células tumorais (CASTANO; MROZ; HAMBLIN, 2006; NOWIS et al., 2005).

As citocinas são mediadores solúveis que controlam o sistema imune e são secretadas por diferentes tipos celulares. Essas moléculas podem atuar de forma autócrina (na própria célula secretora) e parácrina (células vizinhas). Algumas citocinas são conhecidas como interleucinas (IL) e outras receberam um nome próprio. As citocinas são redundantes, várias apresentam atividades similares, como por exemplo, a IL-1 $\beta$ e TNF- $\alpha$ ativam macrófagos e neutrófilos, promovem à diferenciação de células $\mathrm{B}$, induzem a expressão de outras citocinas e mediadores que causam inflamação, por isso, são chamadas de citocinas pró-inflamatórias. Além disto, essas duas citocinas intensificam a ativação de células T auxiliares por APCs. As citocinas também desempenham uma função na carcinogênese, tanto na ativação dos mecanismos efetores do sistema imune, quanto nos mecanismos de progressão do câncer (DRANOFF, 2004; GUVEN-MAIOROV et al., 2014). 
A liberação de citocinas após a TFD causa ativação de vários fatores de transcrição como fator nuclear $\mathrm{kB}(\mathrm{NF}-\mathrm{kB})$, ativador proteico 1 (AP-1- activator protein 1) e ativação do complemento, principais ativados são C3a e C5a. Essas moléculas estão envolvidas na resposta inflamatória, estresse oxidativo e aumento na expressão de várias citocinas (CASTANO; MROZ; HAMBLIN, 2006). Dentre as principais citocinas produzidas por estas moléculas estão a IL-1 $\beta$, IL-6, IL-10 e TNF- $\alpha$ (KORBELIK et al., 2001). A avaliação de várias citocinas no soro de pacientes com mesotelioma pleural tratados pela TFD mediada por Foscan $^{\circledR}$ (Biolitec Pharma Ltd, Dublin, Ireland) comprimento de onda de $652 \mathrm{~nm}$ e dose total de $10 \mathrm{~J} / \mathrm{cm}^{2}$, indicou níveis elevados de IL-1 $\beta$, IL-6, IL-8 e IL-10 (YOM et al., 2003).

A análise da expressão de algumas citocinas pró-inflamatórias foi realizada após tratamento pela TFD-MAL na pele de camundongos, com irradiação por LED, comprimento de onda de $635 \mathrm{~nm}$ e dose total de $25 \mathrm{~J} / \mathrm{cm}^{2}$. Ocorreu aumento na expressão de IL-1 $\beta$ no segundo dia após TFD. A atividade da IL-1 $\beta$ é fundamental para o resultado terapêutico, uma vez que sua neutralização com anticorpos diminuiu as taxas de cura de tumores tratados pela TFD (SUN et al., 2002). No estudo De Vree et al. (1997) verificaram que existe uma relação entre aumento na secreção de IL-1 $\beta$ e aumento de neutrófilos, isto é importante para eficácia da TFD.

A interleucina-2 (IL-2) é secretada pelas APCs e pode determinar a diferenciação de subpopulações de linfócitos $\mathrm{T}$ a partir de células Th0 (imaturas). Após a apresentação do antígeno, as células $\mathrm{T}$ auxiliares são diferenciadas em Th1, produzindo citocinas próinflamatórias como IL-1 $\beta$ e TNF- $\alpha$ que controlam a imunidade adaptativa, na diferenciação e crescimento das células B, secreção de imunoglobulinas opsonizantes, ativação de células T citotóxicas, ativação de neutrófilos e macrófagos. Já os mecanismos da resposta Th2 secretam citocinas anti-inflamatórias como IL-4 e IL-10 que promovem a produção de imunoglobulinas G e E (IgG e IgE), ativação de eosinófilos e supressão da imunidade mediada por células. Portanto, as células Th1 atuam na imunidade celular, enquanto que as células Th2 atuam na imunidade humoral (CASTANO; MROZ; HAMBLIN, 2006; NOWIS et al., 2005).

\subsubsection{Efeitos na vascularização}

Tanto os tecidos tumorais como os sadios requerem um adequado suplemento sanguíneo para manutenção da homeostase. Há evidências que in vivo, a vascularização de tecidos tumorais e sadios é prejudicada após TFD com diferentes FSs. No tratamento contra o câncer, a TFD mostra uma rápida indução de trombose na microcirculação, altera as proteínas 
de adesão na matriz extracelular e afeta o potencial de adesão plaquetária. A TFD pode levar a redução ou aumento da adesão plaquetária na matriz extracelular, o colágeno age como molécula chave neste processo. A matriz extracelular dos vasos com baixa quantidade de colágeno, como em grandes artérias, pode se tornar menos trombogênica após a TFD, ao passo que, vasos com alto conteúdo de colágeno, como arteríolas e veias, podem se tornar mais propensos ao trombo (FUNGALOI et al., 2002).

Maas et al. (2012) verificaram como o microambiente tumoral pode influenciar na resposta tumoral à TFD. Células tumorais foram inoculadas em camundongos com matrigel para criar um microambiente tumoral alterado que inclui alterações na vascularização. O dano vascular induzido pela TFD aumentou em tumores suplementados com matrigel. $\mathrm{O}$ tumor que apresentou mais colágeno exibiu congestão vascular e isquemia após TFD, juntamente com maior probabilidade curativa que foi colágena dependente.

Danos nos vasos sanguíneos durante e após a TFD é regulada por dois processos: constrição de vasos e agregação plaquetária. Lesões nas células endoteliais envolvem alguns alvos, como membrana plasmática, lisossomos, citoesqueleto e mitocôndrias. Alterações na forma das células endoteliais levam à exposição de proteínas da membrana basal subendotelial. Esses danos resultam na liberação do fator de von Willebrand e outros agentes da coagulação sanguínea, como tromboxano que ativam plaquetas. Danos no endotélio resultam na modulação do cálcio que está diretamente ligado às contrações da musculatura lisa dos vasos. Leucócitos polimorfonucleares começam a aderir na parede de vasos danificados e estão provavelmente envolvidos no aumento da permeabilidade vascular (FUNGALOI et al., 2002).

Fingar et al. (1992) mostraram os efeitos da TFD no músculo cremaster de ratos para avaliação de mudanças na constrição de vasos, permeabilidade e adesão de leucócitos. O Photofrin ${ }^{\circledR}$ foi utilizado como FS, o tecido foi exposto à irradiação na dose de $150 \mathrm{~J} / \mathrm{cm}^{2}$, comprimento de luz $630 \mathrm{~nm}$. Quanto maior a dose do FS menos luz foi requerida para provocar a vasoconstrição no tecido. Aumento na adesão leucócitos polimorfonucleares nas paredes das vênulas foi relatado após a TFD.

O tratamento pela TFD foi eficaz em dois relatos de casos de dermatose purpúrica pigmentada que são manchas na pele, há poucas informações sobre o desenvolvimento desta doença, uma das explicações está relacionada com distúrbio ou fraqueza dos vasos sanguíneos que se tornam frágeis e ocorre extravasamento de eritrócitos, também está associada com a imunidade celular ou humoral. Cada caso foi tratado com um tipo de protocolo da TFD, com 
diferente FS e luz, portanto, a dermatose nos dois pacientes demonstrou bom resultado após o tratamento com diminuição no número e tamanho dos vasos (KIM; KIM; KIM, 2009).

Redução na perfusão vascular associada com injúria microvascular causada pela TFD produz hipóxia no tecido tumoral. A hipóxia inicia uma cascata de sinalização que promove a angiogênese (BHUVANESWARI et al., 2008). Em carcinoma mamário de camundongos, a TFD mediada por Photofrin ${ }^{\circledR}$ induziu a expressão do fator de indução de hipóxia (HIF) que aumentou o nível do fator de crescimento do endotélio vascular (VEGF), que é marcador de angiogênese. A TFD pode funcionar como mediador da angiogênese e recorrência do tumor por aumentar a expressão de VEGF dentro da massa tumoral tratada. Ocorreu diminuição nos níveis de VEGF em tumores tratados pela TFD combinada com fatores antiangiogênicos EMAP-II e IM862 comparados com tumores tratados apenas com a TFD. O tratamento com fatores antiangiogênicos pode potencializar a resposta ao tratamento pela TFD, é uma estratégia eficiente para evitar a recorrência de tumores (FERRARIO et al., 2000). 


\section{MATERIAL E MÉTODOS}

\subsection{ANIMAIS}

Para os grupos experimentais foram utilizados 65 camundongos albinos, Swiss webster, fêmeas, com idade de 6 e 7 semanas e peso médio inicial de 26,96 $\pm 2,38 \mathrm{~g}$. Os camundongos foram criados e mantidos no Biotério do Departamento de Patologia da Faculdade de Medicina Veterinária e Zootecnia da Universidade de São Paulo (FMVZ/USP). Os animais foram identificados e separados em gaiolas (cinco animais/gaiola) de acordo com o peso. Os camundongos permaneceram em caixas de policarbonato, com condições controladas de temperatura $\left(20 \pm 4{ }^{\circ} \mathrm{C}\right)$ e umidade relativa do ar (45 a 75\%) com ciclo de 12 horas de claro/escuro. Todos os animais tiveram acesso livre a ração e água filtrada (pH 7.0) por todo o período experimental. Os procedimentos que envolveram os animais nesta pesquisa foram aprovados pelo comitê de bioética da FMVZ /USP (protocolo 1857/2009) e pelo comitê de bioética do Instituto de Ciências Biomédicas (ICB) pelo registro 101.

\subsection{MODELO DE INDUÇÃO DO CARCINOMA ESPINOCELULAR CUTÂNEO}

Um dia antes da aplicação cutânea do carcinógeno iniciador DMBA, os camundongos tiveram os pelos das regiões torácica e lombar dorsal removidos em área de $3 \mathrm{~cm}^{2}$. Cada animal recebeu uma única aplicação tópica de DMBA (Sigma-Aldrich, St. Louis, MO., USA) $200 \mathrm{nmol}(50 \mu \mathrm{g})$ diluído em $200 \mu \mathrm{l}$ de acetona. Uma semana após a utilização do DMBA, cada animal recebeu a aplicação tópica de $8 \mathrm{nmol}(5 \mu \mathrm{g})$ de TPA (Sigma-Aldrich), diluído em $200 \mu 1$ de acetona, 2 vezes na semana, durante 28 semanas. Para as aplicações cutâneas foram usados pipetadores. A metodologia e a dosagem das drogas seguiu o protocolo descrito na literatura com adaptações na dosagem e no tempo de indução pelas drogas (GILLS et al., 2006; KAUR; ATHAR; ALAM, 2010).

\subsection{TRATAMENTO PELA TERAPIA FOTODINÂMICA}

O tratamento pela TFD foi iniciado 24 horas após a última aplicação do TPA. O Azul de Metileno (AM) foi diluído em soro fisiológico para o preparo da solução de AM a 1\%, esta solução foi aplicada por injeção intratumoral e peritumoral até que o tecido ficasse azul escuro, aproximadamente $1 \mathrm{~mL}$ foi injetado no tecido tumoral e no tecido sadio (Figura 5A). 
Para o AM ser absorvido pelo tecido foi necessário esperar 5 minutos para iniciar a irradiação. A fonte de luz utilizada foi o Laser Diodo Arsenieto de Gálio e Alumínio (AsGaAl) da marca Laserline $^{\circledR}$, modelo Inova, potência de $74 \mathrm{~mW} / \mathrm{cm}^{2}$, feixe de área de $2 \mathrm{~cm}^{2}$, com comprimento de onda a $650 \mathrm{~nm}$ por 15 minutos com dose total de $24 \mathrm{~J} / \mathrm{cm}^{2}$ (Figura 5B). Os camundongos receberam anestésico via intraperitoneal de quetamina/xilazina (Cristália, Itapira, SP., Brasil) na dose de $150 \mathrm{mg} / \mathrm{kg}$ e $20 \mathrm{mg} / \mathrm{Kg}$, respectivamente, durante a remoção dos pelos e tratamento pela TFD.

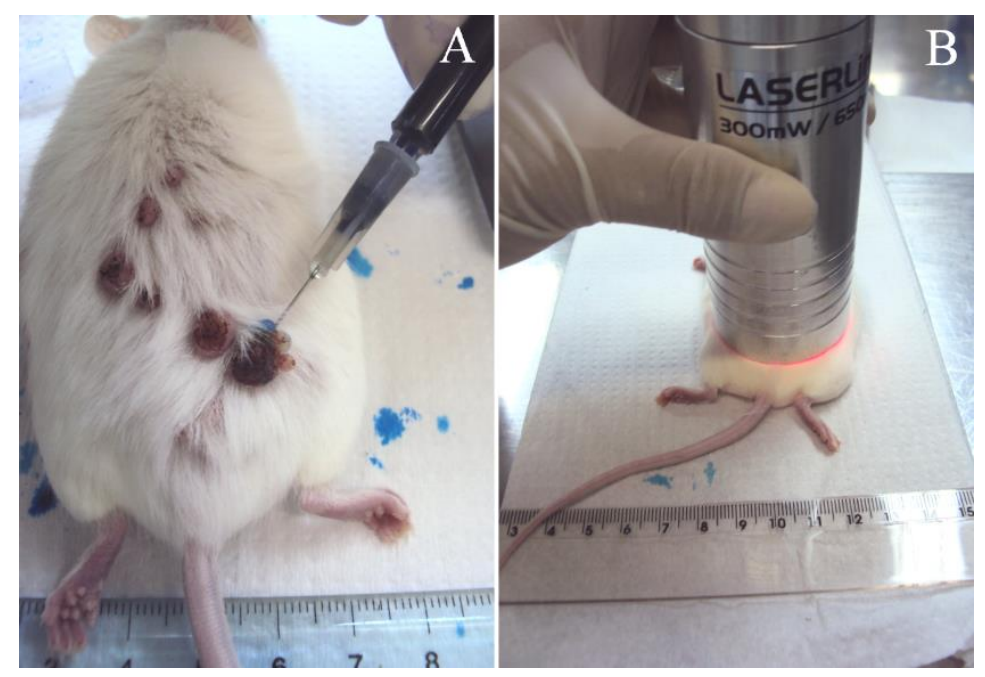

Figura 5 - Tratamento dos tumores de pele pela Terapia Fotodinâmica. (A) Aplicação do azul de metileno intratumoral. (B) Aplicação do laser.

\subsection{DELINEAMENTO EXPERIMENTAL}

\subsubsection{Formação dos Grupos Experimentais}

Os camundongos que foram submetidos à indução do CEC pelas drogas DMBA e TPA foram divididos em quatro grupos experimentais e abatidos em dois períodos diferentes, 24 horas e 15 dias após o tratamento pela TFD, desta forma, contendo dois grupos controles e dois grupos tratados. Os animais sadios foram divididos em três grupos, um grupo controle e dois tratados, que foram abatidos em períodos diferentes, 24 horas e 15 dias após a TFD. No total, os animais foram distribuídos em sete grupos experimentais conforme descrito na Tabela 1. 
Tabela 1 - Delineamento dos grupos experimentais

\begin{tabular}{|c|c|c|c|}
\hline $\begin{array}{c}\text { Grupos } \\
\text { experimentais } \\
\text { (CEC) } \\
\end{array}$ & Procedimento & $\begin{array}{l}\text { Grupos } \\
\text { controle } \\
\text { (acetona) }\end{array}$ & Procedimento \\
\hline $\begin{array}{c}\text { CEC+24 h } \\
(\mathrm{N}=10)\end{array}$ & $\begin{array}{l}\text { Animais induzidos ao CEC sem } \\
\text { tratamento, abatidos junto com os } \\
\text { grupos tratados } 24 \text { horas após } \\
\text { tratamento; }\end{array}$ & $\begin{array}{c}\mathbf{S} \\
(\mathbf{N}=5)\end{array}$ & $\begin{array}{l}\text { Animais sadios que receberam } \\
\text { apenas a aplicação da acetona } \\
\text { durante todo o período } \\
\text { experimental. }\end{array}$ \\
\hline $\begin{array}{c}\mathrm{CEC}+15 \mathrm{~d} \\
(\mathrm{~N}=6)\end{array}$ & $\begin{array}{l}\text { Animais induzidos ao CEC sem } \\
\text { tratamento e abatidos junto com os } \\
\text { grupos tratados } 15 \text { dias após } \\
\text { tratamento; }\end{array}$ & & \\
\hline $\begin{array}{c}\text { CEC+TFD+24 h } \\
(\mathbf{N}=15)\end{array}$ & $\begin{array}{l}\text { Animais induzidos ao CEC, } \\
\text { tratados pela TFD e abatidos } 24 \\
\text { horas após tratamento; }\end{array}$ & $\begin{array}{c}\text { S+TFD+24 h } \\
\quad(\mathbf{N}=7)\end{array}$ & 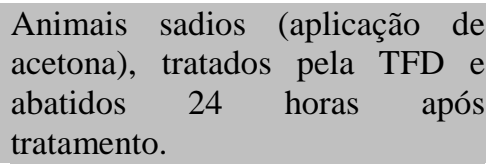 \\
\hline $\begin{array}{c}\text { CEC+TFD+15 d } \\
(\mathbf{N}=15)\end{array}$ & $\begin{array}{l}\text { Animais induzidos ao CEC, } \\
\text { tratados pela TFD e abatidos } 15 \\
\text { dias após tratamento; }\end{array}$ & $\begin{array}{l}\text { S+TFD+15 d } \\
\quad(\mathbf{N}=8)\end{array}$ & $\begin{array}{l}\text { Animais sadios (aplicação de } \\
\text { acetona), tratados pela TFD e } \\
\text { abatidos } 15 \text { dias após tratamento. }\end{array}$ \\
\hline
\end{tabular}

Nota: Abreviaturas:

CEC: carcinoma espinocelular cutâneo;

TFD: terapia fotodinâmica;

S: sadios

$\mathrm{N}$ : número de animais.

\subsubsection{Abate dos animais}

Os grupos tratados foram abatidos nos períodos de 24 horas e 15 dias após a TFD, assim como, os animais dos grupos controles nos períodos coincidentes, conforme demonstrado na Figura 6. Os camundongos foram abatidos mediante a dose excessiva dos anestésicos quetamina e xilazina (CLOSE et al., 1997).

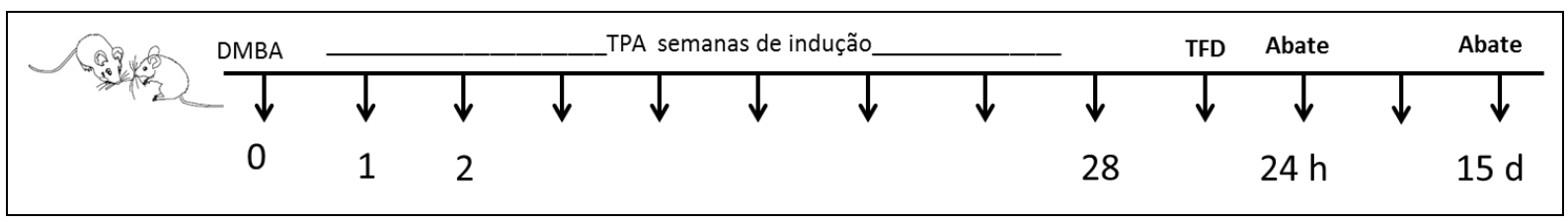

Figura 6 - Período experimental. Início pela aplicação do DMBA, após uma semana, início da aplicação do TPA por 28 semanas, após 24 horas da última aplicação do TPA, a TFD foi realizada, os grupos controles e tratados foram abatidos 24 horas e 15 dias após tratamento.

\subsection{FIXAÇÃO E PROCESSAMENTO DO MATERIAL BIOLÓGICO}

Os fragmentos colhidos foram fixados em solução fixadora de Metacarn (60\% metanol, 30\% clorofórmio e 10\% ácido acético) e em solução de Bouin (50 mL de formol, 20 $\mathrm{mL}$ de ácido acético e q.s.p. $500 \mathrm{~mL}$ de solução saturada de ácido pícrico). Após 12 horas de 
fixação em Metacarn e 6 horas no fixador Bouin, os fragmentos foram processados rotineiramente para inclusão em paraplast (Easypath, Erviegas Instrumental Cirúrgico Ltda, São Paulo, SP, Brasil) segundo recomendações de Suvarna, Layton e Bancroft (2012); Tolosa, Rodrigues e Behmer (2005). O material fixado em Metacarn foi utilizado para o exame histopatológico e técnica de imuno-histoquímica, ao passo que, os fragmentos fixados em solução de Bouin também foram utilizados para a análise histopatológica e avaliação das fibras colágenas com a coloração de Picrosírius. Para a técnica de RT-PCR em tempo real o material foi conservado em RNA later $^{\circledR}$ seguido de armazenamento em freezer a $-80{ }^{\circ} \mathrm{C}$.

A maioria dos tumores mediu menos de $5 \mathrm{~mm}$ de diâmetro, por isso, não foi possível separar os tumores pequenos em muitos fixadores. Tumores maiores que $5 \mathrm{~mm}$ de diâmetro foram separados para mais técnicas. Após exame histopatológico, o número de 5 amostras positivas ao CEC foi obtida para cada grupo experimental, conforme descrito na Tabela 2.

Tabela 2 - Colheita do material biológico e distribuição entre os fixadores

\begin{tabular}{|c|c|c|}
\hline Fixação ou Conservação & Procedimento & Número de tumores \\
\hline Metacarn & $\begin{array}{l}\text { - Avaliação histopatológica pela } \\
\text { coloração de Hematoxilina e } \\
\text { Eosina (HE); } \\
\text { - Técnica de Imuno-histoquímica; } \\
\text { - Técnica de TUNEL; }\end{array}$ & $\begin{array}{l}\text { Mínimo de } 5 \text { tumores para cada } \\
\text { grupos }\end{array}$ \\
\hline Bouin & $\begin{array}{l}\text { - Avaliação histopatológica pela } \\
\text { coloração de HE; } \\
\text { - Avaliação de fibras colágenas } \\
\text { pela coloração de Picrosírius; }\end{array}$ & $\begin{array}{l}\text { Mínimo de } 5 \text { tumores para cada } \\
\text { grupos }\end{array}$ \\
\hline $\begin{array}{l}\text { RNA later armazenamento em } \\
\text { freezer }\left(-80^{\circ} \mathrm{C}\right)\end{array}$ & $\begin{array}{l}\text { - Avaliação Histopatológica pela } \\
\text { coloração de HE; } \\
\text { - RT-PCR em tempo real; }\end{array}$ & $\begin{array}{l}\text { Mínimo de } 5 \text { tumores para cada } \\
\text { grupos }\end{array}$ \\
\hline
\end{tabular}

\subsection{AVALIAÇÃO MACROSCÓPICA}

Os animais foram pesados semanalmente, os quatro primeiros tumores que surgiram em cada animal foram acompanhados e observados. Fotografias para a avaliação morfológica e a análise do tamanho de cada tumor em diâmetro com o auxílio de paquímetro foram realizadas ao longo do período experimental.

\subsection{AVALIAÇÃO HISTOPATOLÓGICA}

A avaliação histopatológica do CEC foi realizada segundo a classificação proposta por Broders (1921) cujos critérios são recomendados pela Organização Mundial de Saúde 
(LeBOIT et al., 2006). Nesta avaliação, os tumores bem diferenciados (grau I) possuem arquitetura tecidual que se assemelha ao padrão normal de epitélio escamoso; os tumores moderadamente diferenciados (grau II) tem predomínio de células imaturas, numerosas mitoses típicas e atípicas com mínima queratinização; os poucos diferenciados (grau III) apresentam certo grau de pleomorfismo nuclear, atividade mitótica e pouca queratinização.

Os tumores foram incluídos em paraplast e lâminas contendo secções destes tumores na espessura de $5 \mu \mathrm{m}$ foram preparadas e coradas em HE. Essas lâminas foram avaliadas por dois patologistas independentes e foram classificadas de acordo com os critérios para graduação histopatológica do CEC definido acima.

Após a avaliação histopatológica dos tumores, apenas os exemplares positivos ao CEC foram analisados para as demais técnicas. Por causa da variação de tamanho e das características macro e microscópicas observadas nos tumores, que diferiram entre os animais e também no mesmo animal, cada tumor foi considerado como uma unidade amostral e não o número de animais. Desta forma, igualamos o número amostral para 5 para todos os grupos, tanto para os tumores CEC-positivos como para as amostras sadias.

\subsection{AVALIAÇÃO DO COLÁGENO TIPO I}

Para a avaliação do colágeno foram utilizadas amostras fixadas na solução de Bouin. Após várias lavagens com álcool $70^{\circ}$ para a retirada do excesso do fixador, as amostras foram processadas histologicamente. As lâminas foram desparafinizadas e hidratadas, receberam tratamento com ácido fosfomolíbdico por 1 minuto e depois foram coradas por Picrosírius por 1 hora (MONTES; JUNQUEIRA, 1991). Em seguida, as lâminas foram desidratadas em graduação crescente de álcoois, diafanizadas em xilóis e montadas em meio de resina Permount (Fisher Scientific, New Jersey, USA).

Para quantificar a distribuição de colágeno nas amostras positivas ao CEC foram usados 10 campos não sequenciais apenas nas áreas de formação tumoral, as regiões dérmicas e pele sadia ao redor do tumor não foram incluídas nas análises. As amostras de pele sadias foram analisadas, 10 campos não sequenciais na área da derme foram utilizados, áreas que continham pelos e glândulas não entraram na análise. A quantificação das fibras colágenas foi realizada por análise de cor utilizando o software Image J (NIH Image, Bethesda, Maryland, USA), no aumento de 400x para as amostras de CEC e aumento de 1.000x para as amostras de pele sadia. A porcentagem média de colágeno foi obtida pela razão entre a medida da área preenchida por colágeno pela área total do campo fotomicrografado para cada aumento. 


\subsection{TÉCNICA DE IMUNO-HISTOQUÍMICA}

Secções com 3-5 $\mu \mathrm{m}$ de espessura foram depositadas sobre lâminas de vidro silanizadas e depois colocadas em estufa à $57^{\circ} \mathrm{C}$ por 30 minutos para maior aderência do corte. Depois, essas lâminas foram submetidas à técnica de desparafinização e hidratação. Posteriormente, as lâminas receberam tratamento para recuperação antigênica. Todas as lavagens foram realizadas com tampão de lavagem Phosphate Buffer Sodium (PBS) pH 7.4 ou Tris-Buffered Saline and Tween (TBST) $\mathrm{pH}$ 7.4-7.6 por 3 vezes de 5 minutos cada. Em seguida, o bloqueio da peroxidase endógena foi realizado seguido pelo bloqueio de reações inespecíficas, ambos em temperatura ambiente (T. A.). Os cortes foram lavados e incubados com anticorpo primário por no mínimo 12 horas à $4{ }^{\circ} \mathrm{C}$. Após lavagens, as lâminas foram incubadas com polímero por 30 minutos em T. A. Após lavagens, as lâminas foram reveladas pelo cromógeno $\mathrm{DAB}$, em seguida, os cortes foram contracorados com Hematoxilina de Harris por 15 segundos. Após a coloração, as lâminas foram lavadas em água corrente por 5 minutos, em seguida, os cortes foram desidratados, diafanizados e montados em meio de resina Permount. O controle negativo foi obtido pela retirada do anticorpo primário com incubação das lâminas apenas com o diluente e pela incubação da IgG endógena (LifeSpan Biosciences, Seattle, WA, USA) semelhante à imunoglobulina de coelho anti-camundongo que foram produzidos os anticorpos primários. Os controles positivos consistiram de tecidos que continham a proteína conhecida. Os anticorpos primários utilizados e suas especificações estão descritos na Tabela 3. 
Tabela 3 - Anticorpos e suas especificações

\begin{tabular}{|c|c|c|c|c|c|}
\hline Anticorpos & Fornecedores & Titulação & $\begin{array}{c}\text { Recuperação } \\
\text { antigênica }\end{array}$ & $\begin{array}{l}\text { Bloqueio da } \\
\text { peroxidase }\end{array}$ & $\begin{array}{l}\text { Bloqueio de } \\
\text { reações } \\
\text { inespecíficas }\end{array}$ \\
\hline $\begin{array}{l}\text { PCNA (clone } \\
\text { PC10) }\end{array}$ & $\begin{array}{c}\text { Santa Cruz } \\
\text { Biotec. (SC-56) }\end{array}$ & $1: 200$ & $\begin{array}{c}\text { Tampão citrato } \\
\text { pH } 6.0 \text { por } 3 \mathrm{x} 4 \\
\text { minutos no } \\
\text { micro-ondas }\end{array}$ & $\begin{array}{c}\text { Peróxido de } \\
\text { hidrogênio do } \\
\text { Kit } \\
\text { Novolink }^{\circledR *} \\
\text { por } 30 \\
\text { minutos em } \\
\text { T.A. }\end{array}$ & $\begin{array}{l}\text { Protein block, } \\
\text { Kit Novolink* } \\
\text { por } 30 \text { minutos } \\
\text { em T.A. }\end{array}$ \\
\hline $\begin{array}{l}\text { Caspase } 3 \\
\text { clivada } \\
\text { policlonal }\end{array}$ & $\begin{array}{c}\text { Biovision } \\
(\text { BIOV-3015- } \\
100)\end{array}$ & $1: 100$ & $\begin{array}{l}\text { Tampão EDTA } \\
1 \mathrm{mM} \mathrm{pH} 8.0 \text { na } \\
\text { panela de } \\
\text { pressão elétrica } \\
\text { por } 15 \text { minutos }\end{array}$ & $\begin{array}{c}\text { Peróxido de } \\
\text { hidrogênio do } \\
\text { Kit Novolink* } \\
\text { por } 30 \\
\text { minutos em } \\
\text { T.A. }\end{array}$ & $\begin{array}{c}\text { Protein block, } \\
\text { Kit Novolink* } \\
\text { por } 30 \text { minutos } \\
\text { em T.A. }\end{array}$ \\
\hline $\begin{array}{c}\text { CD8 } \\
\text { policlonal }\end{array}$ & $\begin{array}{l}\text { Abbiotec } \\
(250596)\end{array}$ & $1: 500$ & $\begin{array}{c}\text { Tampão } \\
\text { Tris/EDTA pH } \\
9.0 \text { na panela de } \\
\text { pressão elétrica } \\
\text { por } 18 \text { minutos }\end{array}$ & $\begin{array}{c}\text { Peróxido de } \\
\text { hidrogênio a } \\
3 \% \text { diluído em } \\
\text { metanol por } \\
30 \text { minutos em } \\
\text { T.A. }\end{array}$ & $\begin{array}{c}\text { Protein block, } \\
\text { Kit Novolink* } \\
\text { por } 1 \text { hora em } \\
\text { T.A. }\end{array}$ \\
\hline $\begin{array}{c}\text { Fator de von } \\
\text { Willebrand } \\
\text { policlonal }\end{array}$ & $\begin{array}{l}\text { Millipore } \\
\text { (AB7356) }\end{array}$ & $1: 200$ & $\begin{array}{c}\text { Tampão } \\
\text { Tris/EDTA pH } \\
9.0 \text { na panela de } \\
\text { pressão elétrica } \\
\text { por } 15 \text { minutos }\end{array}$ & $\begin{array}{c}\text { Peróxido de } \\
\text { hidrogênio a } \\
3 \% \text { diluído em } \\
\text { metanol por } \\
20 \text { minutos em } \\
\text { T.A. }\end{array}$ & $\begin{array}{l}\text { Protein block, } \\
\text { Kit Novolink* } \\
\text { por } 30 \text { minutos } \\
\text { em T.A. }\end{array}$ \\
\hline $\begin{array}{c}\text { H-ras } \\
\text { policlonal }\end{array}$ & $\begin{array}{c}\text { Santa Cruz } \\
\text { Biotec. (SC- } \\
520)\end{array}$ & $1: 200$ & $\begin{array}{c}\text { Tampão Citrato } \\
\text { pH } 6.0 \text { na } \\
\text { panela de } \\
\text { pressão elétrica } \\
\text { por } 10 \text { minutos }\end{array}$ & $\begin{array}{c}\text { Peróxido de } \\
\text { hidrogênio a } \\
10 \% \text { diluído } \\
\text { em metanol } \\
\text { por } 20 \\
\text { minutos em } \\
\text { T.A. }\end{array}$ & $\begin{array}{l}\text { Leite desnatado } \\
\text { em pó } 10 \% \text { por } \\
30 \text { minutos à } 37 \\
{ }^{\circ} \mathrm{C}\end{array}$ \\
\hline $\begin{array}{c}\text { p53 } \\
\text { policlonal }\end{array}$ & $\begin{array}{c}\text { Santa Cruz } \\
\text { Biotec. (SC- } \\
\text { 6243) }\end{array}$ & $1: 200$ & $\begin{array}{c}\text { Tampão } \\
\text { Tris/EDTA pH } \\
9.0 \text { na panela de } \\
\text { pressão elétrica } \\
\text { por } 15 \text { minutos }\end{array}$ & $\begin{array}{c}\text { Peróxido de } \\
\text { hidrogênio a } \\
10 \% \text { diluído } \\
\text { em metanol } \\
\text { por } 30 \\
\text { minutos em } \\
\text { T.A. }\end{array}$ & $\begin{array}{c}\text { Leite desnatado } \\
\text { em pó } 10 \% \text { por } \\
10 \text { minutos à } 37 \\
{ }^{\circ} \mathrm{C}\end{array}$ \\
\hline $\begin{array}{c}\text { Bak } \\
\text { policlonal }\end{array}$ & $\begin{array}{l}\text { Sigma-Aldrich } \\
\text { (PRS3347) }\end{array}$ & $1: 500$ & $\begin{array}{c}\text { Tampão Citrato } \\
\text { pH } 6.0 \text { na } \\
\text { panela de } \\
\text { pressão elétrica } \\
\text { por } 10 \text { minutos }\end{array}$ & $\begin{array}{c}\text { Peróxido de } \\
\text { hidrogênio a } \\
10 \% \text { diluído } \\
\text { em metanol } \\
\text { por } 15 \\
\text { minutos em } \\
\text { T.A. }\end{array}$ & $\begin{array}{c}\text { Leite desnatado } \\
\text { em pó } 10 \% \text { por } \\
30 \text { minutos à } 37 \\
{ }^{\circ} \mathrm{C}\end{array}$ \\
\hline $\begin{array}{c}\text { Bcl-xL } \\
\text { policlonal }\end{array}$ & $\begin{array}{l}\text { Biovision } \\
(3312-100)\end{array}$ & $1: 500$ & $\begin{array}{c}\text { Tampão } \\
\text { Tris/EDTA pH } \\
9.0 \text { na panela de } \\
\text { pressão elétrica } \\
\text { por } 10 \text { minutos }\end{array}$ & $\begin{array}{c}\text { Peróxido de } \\
\text { hidrogênio a } \\
10 \% \text { diluído } \\
\text { em metanol } \\
\text { por } 15 \\
\text { minutos em } \\
\text { T.A. }\end{array}$ & $\begin{array}{c}\text { Soro de cabra } \\
10 \% \text { por } 30 \\
\text { minutos. em } \mathrm{T} \text {. } \\
\text { A. }\end{array}$ \\
\hline
\end{tabular}


A avaliação da expressão do PCNA foi realizada por meio da quantificação dos núcleos positivos corados em marrom e/ou cor castanha independente da intensidade da coloração pela revelação com o DAB. Em cada grupo induzido ao CEC foram contados 500 núcleos de queratinócitos nas áreas de invasão tumoral, da mesma forma, nas amostras sadias foram contados 500 núcleos de queratinócitos nos estratos da epiderme. A contagem foi realizada no aumento de $1.000 x$. O índice de positividade (IP) em \% para o PCNA foi obtido por meio da fórmula:

$$
\mathbf{I P}=\frac{\text { Número de núcleos positivos }}{500 \text { núcleos aleatórios }} \times 100
$$

Para a avaliação da caspase 3 clivada foram contadas 500 células, nas quais marcações citoplasmáticas independente da intensidade da coloração pela revelação com o DAB foram consideradas positivas. Da mesma forma que o PCNA, também foi realizado o IP (\%) nesta avaliação utilizando o aumento de 1.000x.

$\mathrm{O}$ antígeno $\mathrm{CD} 8$ foi avaliado qualitativamente. As marcações positivas às proteínas $\mathrm{H}$ ras, p53, Bak e Bcl-xL foram avaliadas qualitativamente e de forma semiquantitativa. A intensidade da marcação dos antígenos foi determinada por escores que indicaram: (-) marcação negativa, $(+)$ marcação fraca, $(++)$ marcação moderada e (+++) marcação forte. Na avaliação semiquantitativa foi examinada a distribuição de células positivas à marcação imuno-histoquímica, em que os escores representam: (-) 0-5\% de células positivas, (+) 5-25\% de células positivas, $(++) 25-50 \%$ de células positivas, $(+++) 50-75 \%$ de células positivas e $(++++)$ mais de $75 \%$ de células positivas.

\subsection{TÉCNICA DE TUNEL (terminal deoxynucleotidyl transferase-mediated dUTP nick end-labeling)}

Secções de $3 \mu \mathrm{m}$ de espessura foram colocadas em estufa à $57^{\circ} \mathrm{C}$ por 30 minutos, em seguida desparafinizadas e hidratadas. O protocolo foi realizado conforme as instruções do kit de detecção POD (Horseradish peroxidase) (Roche Diagnostics, Basel, Switzerland) que é um anticorpo marcado com peroxidase. Posteriormente, as lâminas foram incubadas por imersão em solução de proteinase K (Roche Diagnostics) $20 \mu \mathrm{g} / \mathrm{mL}$ diluída em Tampão Tris$\mathrm{HCl}$ pH 7.4 por 30 minutos em estufa à $37^{\circ} \mathrm{C}$. Para todas as lavagens desta técnica foi utilizado Tampão PBS pH 7.4, 3 vezes de 5 minutos cada. Após a digestão proteica, foi 
realizado o bloqueio da peroxidase endógena com peróxido de hidrogênio a $10 \%$ diluído em PBS por 1 hora em T.A. Em seguida, as lâminas foram incubadas por 1 hora em estufa à 37 ${ }^{\circ} \mathrm{C}$ na solução de reação do kit TUNEL. Anteriormente a esta reação, a lâmina de controle positivo foi incubada com solução de DNase por 15 minutos em estufa à $37^{\circ} \mathrm{C}$. Junto com as amostras, também foi adicionado uma lâmina de controle negativo apenas com a solução tampão. Após lavagens, as lâminas foram incubadas com $50 \mu \mathrm{l}$ de Converter-POD por 30 minutos em estufa à $37^{\circ} \mathrm{C}$. Em seguida, as lâminas foram reveladas por DAB e contracoradas por Hematoxilina de Harris, depois desidratadas, diafanizadas e montadas em meio de resina Permount.

A avaliação dos núcleos positivos à técnica de TUNEL foi realizada pela quantificação dos núcleos positivos corados em marrom independente da intensidade da marcação pela revelação com o DAB. Em cada grupo induzido ao CEC invasivo foram contados 500 núcleos nas áreas displásicas do epitélio, da mesma forma, nas amostras sadias foram contados núcleos marcados nos estratos da epiderme. A contagem foi realizada no aumento de 1.000x e o IP (\%) foi obtido por meio da fórmula:

$$
\mathbf{I P}=\frac{\text { Número de núcleos positivos }}{500 \text { núcleos aleatórios }} \times 100
$$

\subsection{TÉCNICA DE ELISA (Enzyme-Linked Immunosorbent Assay)}

Este ensaio foi realizado para a quantificação de citocinas no plasma de cada animal. Amostras de sangue foram coletadas por punção cardíaca em tubos previamente heparinizados a fim de evitar a formação de coágulo após a morte dos animais. As amostras de sangue foram centrifugadas a $1209,6 \mathrm{G}$ por 10 minutos para a separação do plasma, em seguida, foram armazenadas em freezer à $-80^{\circ} \mathrm{C}$ até a análise.

As citocinas TNF- $\alpha$, IL-1 $\beta$ e IL-2 da marca Quantikine ${ }^{\circledR}$ ELISA (R\&D Systems, Inc. Minneapolis, USA) foram analisadas utilizando o kit para imunoensaio enzimático quantitativo do tipo sanduíche. Todas as amostras foram quantificadas em duplicata. No ensaio, padrões, controles e amostras foram incubados em cavidades de microtitulação revestidas com anticorpo monoclonal para TNF- $\alpha$, IL-1 $\beta$ e anticorpo policlonal para IL-2. Após incubação e lavagens, as cavidades foram tratadas com anticorpo conjugado e após nova incubação e lavagens, foram incubadas com solução substrato. Uma solução de interrupção foi adicionada e o grau de reposição enzimática do substrato foi determinado por medida de 
absorbância em leitor de ELISA (Spectra Max Plus - Molecular Devices) a 450 nm e 540 nm; a quantificação foi feita pelo software Softmax PRO. O ensaio foi realizado conforme as instruções do fabricante.

\subsection{AVALIAÇÃO DA EXPRESSÃO GÊNICA POR RT-PCR EM TEMPO REAL}

\subsubsection{Extração do RNA}

A extração do RNA foi realizada pelo kit RNAspin Mini Isolation Kit (GE Healthcare, Buckinghamshire, U.K.) conforme as instruções do fabricante. Aproximadamente $30 \mathrm{mg}$ de cada tecido tumoral e sadio foram macerados com pistilo em cadinho, previamente autoclavados, todos limpos com solução de RNAse away, em seguida, transferidos para $350 \mu 1$ da solução de lise RA1 (Kit) e nesta solução foi acrescentado 3,5 $\mu 1$ de $\beta$-mercaptoetanol. Após, a mistura foi transferida para colunas de extração. A mistura foi lavada e purificada por uma série de reagentes fornecidos pelo fabricante, assim como, pelas colunas de extração, até a etapa final com a liberação do RNAm que foi armazenado em freezer $-80{ }^{\circ} \mathrm{C}$ até o momento do uso.

\subsubsection{Determinação e Quantificação do RNA total}

Para a verificação da integridade do RNA uma alíquota de $10 \mu \mathrm{l}$ foi retirada do RNAm. A alíquota do RNAm extraído foi transferida para um gel de agarose a 1,5\%, está diluída em TAE 1X (48,4 g de Tris base; 20 mL de EDTA 0,5M, pH8,0; 11,4 mL de ácido acético; água deionizada autoclavada q.s.p. $1.000 \mathrm{~mL}$ ), 80V, por 1,5 hora. Previamente, foi acrescido nas amostras de RNA um corante Blue Green Loading Dye I (LGC Biotecnologia) que após eletroforese, as bandas $28 \mathrm{~S}$ e $18 \mathrm{~S}$ em luz UV no aparelho ImageQuant (GE Healthcare) tornaram-se evidenciadas. A presença e correta identificação das bandas indicaram a qualidade do RNA. A concentração do RNA total foi demonstrada em Biofotômetro (Eppendorf, Hamburg, Germany); a relação da absorbância 260/280 nm entre

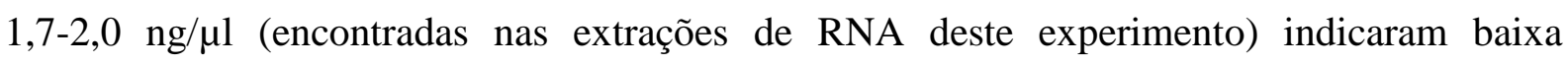
contaminação do RNA, significando que as amostras puderam ser usadas para a transcrição reversa. 


\subsubsection{Obtenção do DNA complementar (cDNA)}

Uma alíquota do RNA extraído foi retirada e para extinguir qualquer resto de DNA, o RNA foi tratado com $1 \mu 1$ da solução de DNAse I para $4 \mu \mathrm{g} / \mu 1$ de RNA total. Os eppendorfs foram mantidos em T. A. por 15 minutos, em seguida foi adicionado $1 \mu 1$ de EDTA (25mM) para bloquear a ação da enzima e depois foram aquecidos por 10 minutos à $65{ }^{\circ} \mathrm{C}$ em termociclador. As amostras receberam $1 \mu \mathrm{l}$ de Oligo DT; $1 \mu \mathrm{l}$ de dNTPS (mix 10mM-2,5mM de cada dNTPS) e posteriormente foram incubadas à $65{ }^{\circ} \mathrm{C}$ por 5 minutos. No gelo, as amostras receberam em cada tubo $4 \mu \mathrm{l}$ do Buffer $5 \mathrm{X}$ (superscript II); $2 \mu \mathrm{l}$ de DDT 1M; $1 \mu \mathrm{l}$ de RNAse OUT seguido de incubação de 2 minutos à $42^{\circ} \mathrm{C}$. Foi adicionado $1 \mu 1$ da enzima transcrição reversa superscript II e as amostras foram incubadas à $42{ }^{\circ} \mathrm{C}$ por 50 minutos, com posterior incubação por $70{ }^{\circ} \mathrm{C}$ por 15 minutos. $\mathrm{O}$ cDNA foi armazenado em freezer $-20{ }^{\circ} \mathrm{C}$ até o momento de sua amplificação. Todos os reagentes usados foram fornecidos pela Invitrogen Life Technologies.

\subsubsection{Assays e probes}

Os TaqMan probes foram marcados com corante fluorescente reporter, FAM (6carboxifluoresceína) na extremidade 5' e corante fluorescente quencher, TAMRA (6-carboxitetrametil-rodamina) na extremidade 3'. No Quadro 1 está demonstrado os assays utilizados. Todos os reagentes foram fornecidos pela empresa Invitrogen Life Technologies.

\begin{tabular}{|c|c|}
\hline Genes & Assays (ID) \\
\hline 18S (controle endógeno) & 4352930E \\
H-ras & Mm01275932_g1 \\
p53 & Mm01731290_g1 \\
Bak & Mm00432045_m1 \\
Bcl-xL & Mm00437783_m1 \\
\hline
\end{tabular}

Quadro 1 - Assays para análise da expressão gênica por RT-PCR em tempo real. Todos da empresa Invitrogen Life Technologies.

\subsubsection{Quantificação da expressão gênica por PCR em tempo real}

Para a avaliação da expressão gênica foram colocados $5 \mu 1$ de cada produto da PCR (cerca de $10 \mathrm{ng}$ do RNA total), tampão A TaqMan $1 \mathrm{X}, \mathrm{MgCl}_{2}$ 5,5 mM, $200 \mu \mathrm{M}$ de dATP, dCTP, dGTP, $400 \mu \mathrm{M}$ dUTP, $200 \mathrm{nM}$ dos primers (senso e anti-Senso), $10 \mathrm{nM}$ das probes TaqMan, 0,01U/mL de AmpErase e 0,025 U/ $\mu 1$ da DNA polimerase AmpliTaq Gold no 
volume total de $50 \mu \mathrm{l}$ em tubos Optical Tubes (Applied Byosystem) apropriados. Todas as reações foram corridas em duplicata e realizadas em termociclador ABI 7300 Sequence Detection System ${ }^{\circledR}$ (Applied Biosystems). As condições de amplificação utilizadas foram: 2 minutos a $50{ }^{\circ} \mathrm{C}, 10$ minutos a $95^{\circ} \mathrm{C}$, seguidos de 50 ciclos a $95{ }^{\circ} \mathrm{C}$ por 15 segundos para a desnaturação da fita de cDNA e a $60{ }^{\circ} \mathrm{C}$ por 1 minuto para a sua extensão. A interpretação dos resultados foi realizada pelo método comparativo em que a expressão relativa dos genes corresponde $2^{-\Delta \Delta C t}$ (LIVAK; SCHMITTGEN, 2001).

\subsection{ANÁLISE ESTATÍSTICA}

Os dados com distribuição normal foram expressos por média (M) e Desvio Padrão (DP). Os dados foram comparados aos pares e o teste utilizado foi o teste $t$-Student. Para avaliação de mais dados foi utilizado o teste ANOVA seguido pelo teste de Tukey-Kramer para amostras com distribuição normal. A curva de sobrevivência foi realizada pelo teste Kaplan-Meier. O nível de significância foi de 5\% para todos os testes realizados. 


\section{RESULTADOS}

Os resultados foram organizados em subseções relativas às alterações macroscópicas e microscópicas após o tratamento pela TFD.

\subsection{ASPECTOS MACROSCÓPICOS}

Os aspectos macroscópicos contemplam os resultados obtidos da avaliação do peso, mortalidade, desenvolvimento dos tumores, tamanho dos tumores e aspectos morfológicos.

\subsubsection{Peso}

A evolução do peso médio dos animais foi avaliada ao longo de todo o período experimental. Foram poucas as variações obtidas com o peso de cada grupo experimental durante o experimento. Todos os grupos apresentaram aumento significativo $(P<0,05)$ no peso em relação à primeira semana experimental com as demais semanas analisadas $\left(14^{\mathrm{a}}\right.$ semana até o abate dos animais). Não foi observada diferença significativa $(P>0,05)$ no peso dos animais tratados com a TFD em relação ao dia do abate (Tabela 4).

Tabela 4 - Média e desvio padrão $(\mathrm{M} \pm \mathrm{DP})$ do peso corporal $(\mathrm{g})$ dos animais durante o período experimental

\begin{tabular}{|c|c|c|c|c|c|}
\hline $\begin{array}{c}\text { Grupos } \\
\text { experimentais }\end{array}$ & $1^{\mathrm{a}}$ semana & $14^{\mathrm{a}}$ semana & $28^{\mathrm{a}}$ semana & TFD & Abate \\
\hline $\begin{array}{c}\mathrm{CEC}+24 \mathrm{~h} \\
(\mathrm{n}=10)\end{array}$ & $29,80 \pm 2,78^{a}$ & $40,80 \pm 3,22^{b}$ & $43,80 \pm 4,78^{\mathrm{bc}}$ & - & $44,10 \pm 4,36^{c}$ \\
\hline $\begin{array}{c}\mathrm{CEC}+\mathrm{TFD}+24 \mathrm{~h} \\
(\mathrm{n}=14)\end{array}$ & $28,64 \pm 3,93^{\mathrm{a}}$ & $41,86 \pm 5,40^{b}$ & $44,86 \pm 5,57^{b}$ & $44,36 \pm 6,21^{b}$ & $44,50 \pm 5,73^{b}$ \\
\hline $\begin{array}{c}\mathrm{CEC}+15 \mathrm{~d} \\
(\mathrm{n}=6)\end{array}$ & $27,67 \pm 0,82^{a}$ & $35,17 \pm 3,19^{b}$ & $34,83 \pm 2,32^{b}$ & - & $33,83 \pm 2,32^{b}$ \\
\hline $\begin{array}{c}\mathrm{CEC}+\mathrm{TFD}+15 \mathrm{~d} \\
(\mathrm{n}=13)\end{array}$ & $27,23 \pm 2,55^{\mathrm{a}}$ & $39,00 \pm 4,21^{b}$ & $42,00 \pm 5,24^{b}$ & $42,54 \pm 5,19^{b}$ & $42,85 \pm 5,29^{b}$ \\
\hline$S(n=5)$ & $25,00 \pm 1,87^{\mathrm{a}}$ & $36,40 \pm 5,86^{b}$ & $41,80 \pm 4,43^{b}$ & - & $40,20 \pm 4,38^{b}$ \\
\hline $\begin{array}{c}\mathrm{S}+\mathrm{TFD}+24 \mathrm{~h} \\
(\mathrm{n}=7)\end{array}$ & $22,71 \pm 1,38^{a}$ & $36,57 \pm 2,64^{b}$ & $43,14 \pm 5,01^{\mathrm{c}}$ & $44,29 \pm 4,54^{\mathrm{c}}$ & $43,86 \pm 4,52^{c}$ \\
\hline $\begin{array}{c}\mathrm{S}+\mathrm{TFD}+15 \mathrm{~d} \\
(\mathrm{n}=7)\end{array}$ & $27,71 \pm 2,24^{\mathrm{a}}$ & $38,43 \pm 1,40^{b}$ & $42,14 \pm 5,60^{b c}$ & $43,14 \pm 3,53^{c}$ & $41,86 \pm 2,34^{b c}$ \\
\hline
\end{tabular}

Nota: Letras diferentes na mesma linha representam diferenças significativas $(P<0,05)$. Teste ANOVA seguido pelo teste de Tukey-Kramer.

Abreviaturas: CEC: Carcinoma Espinocelular Cutâneo

S: Sadios

TFD: Terapia Fotodinâmica 


\subsubsection{Mortalidade}

Durante todo o período experimental quatro animais morreram (6\%). Um animal do grupo CEC+TFD+15 d morreu após o tratamento pela TFD. Os demais animais morreram durante o período de aplicação dos carcinógenos (Figura 7).

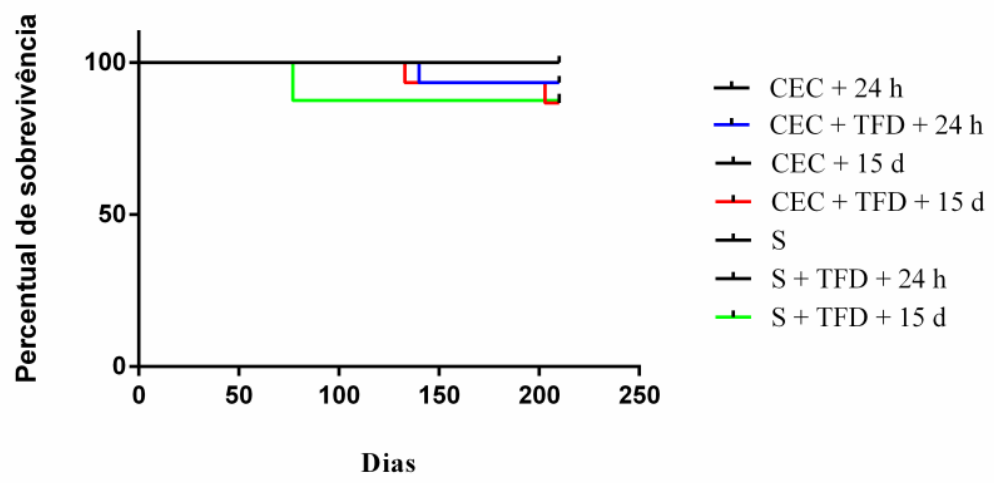

Figura 7 - Curva de sobrevivência dos camundongos controles e tratados. Não ocorreu diferença significativa entre os grupos $(P>0,05)$. Teste de Kaplan-Meier.

\subsubsection{Desenvolvimento dos tumores}

Os primeiros tumores surgiram entre a $7^{\mathrm{a}}$ e $9^{\mathrm{a}}$ semanas de aplicação do TPA em $25 \%$ dos animais, a maioria (45\%) desses tumores surgiu na $11^{\mathrm{a}}$ semana de aplicação da droga promotora. No desenvolvimento dos tumores, variações na morfologia e no tamanho entre os animais foram observadas, mesmo entre os tumores do mesmo animal. O processo evolutivo dos tumores geralmente iniciava com a formação de uma espinha queratinizada (Figura 8A) que em seguida formava uma pápula rosada (Figura 8B). Estes tumores cresciam tornando um aspecto verrugoso que apresentavam alta vascularização e formato nodular (Figura 8C), alguns tumores permaneceram nesse tipo de morfologia durante todo o período experimental. Portanto, outros tumores mostraram crescimento infiltrativo e apresentaram bordas laterais com superfície irregular, com formato que lembrava uma couve-flor (Figura 8D). 


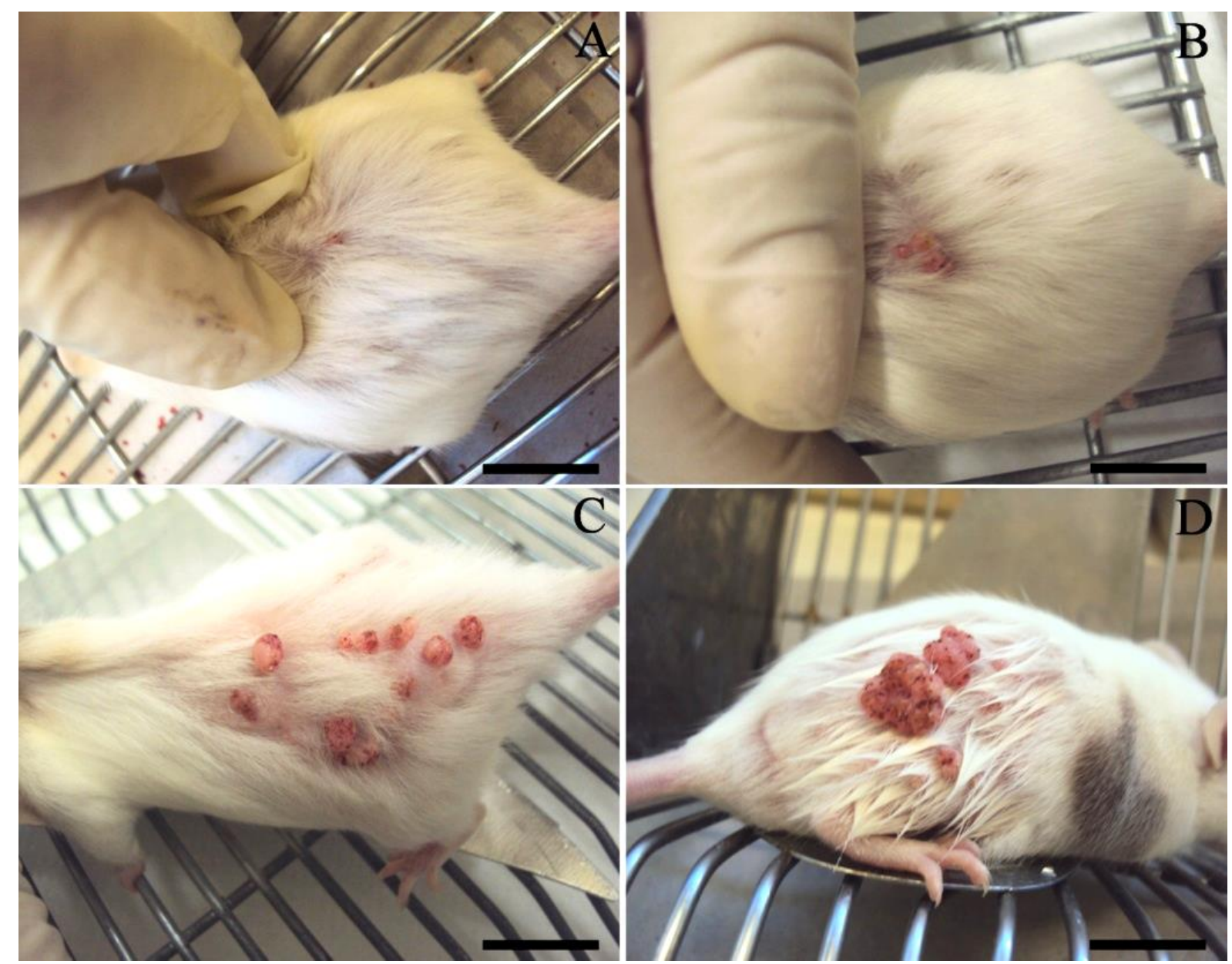

Figura 8 - Diferentes estágios do desenvolvimento dos tumores de pele induzidos em camundongos Swiss pelos carcinógenos DMBA/TPA. (A) Formação de uma espinha queratinizada. (B) Formação de pápula avermelhada. (C) Observar tumores com formato nodular. (D) Estágio mais avançado do tumor com formação de bordas laterais. Barra $=4 \mathrm{~cm}$.

A incidência de tumores foi de $100 \%$ em todos os grupos experimentais. No final das 28 semanas de aplicação do TPA, apenas dois animais não apresentaram tumores na pele, pois estes tumores regrediram (Figura 9). 

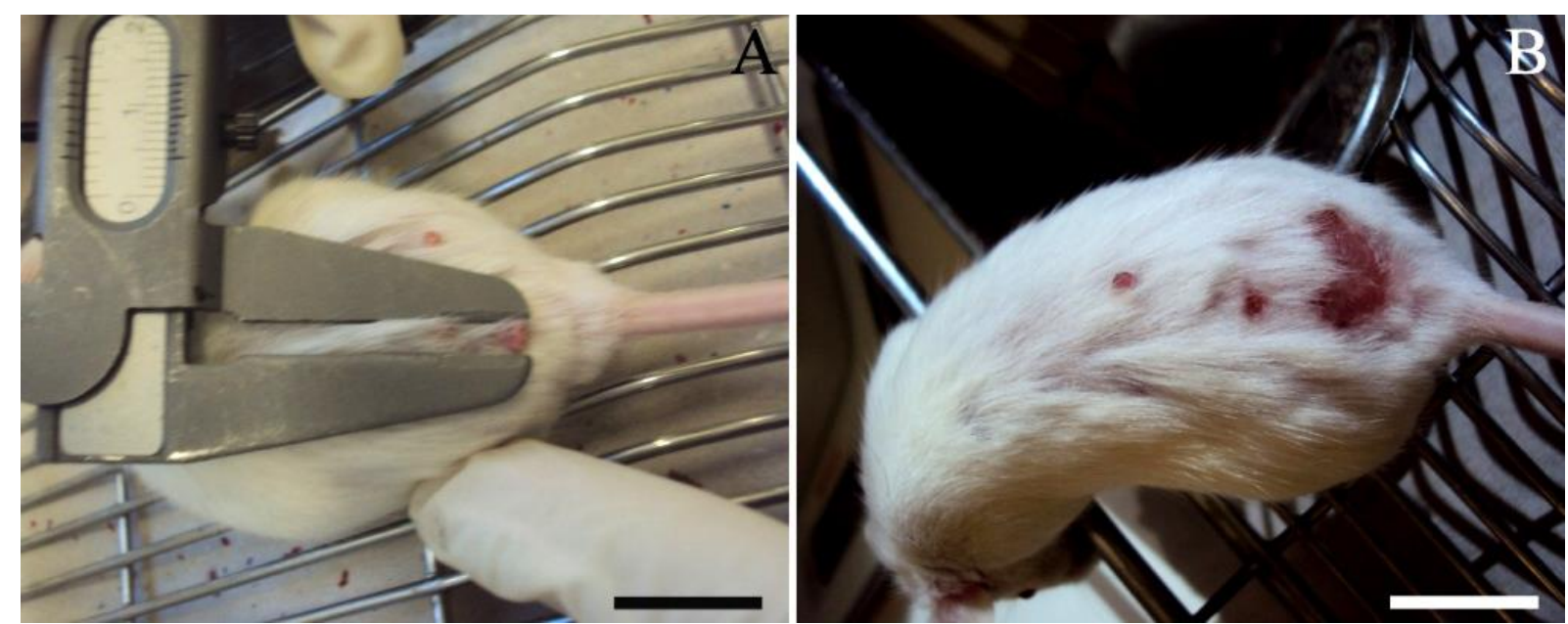

Figura 9 - Imagens representativas da regressão dos tumores de pele induzidos em camundongos Swiss pelos carcinógenos DMBA/TPA. (A) Camundongo na $15^{\mathrm{a}}$ semana de aplicação do TPA, medição do tumor na região lombar pelo paquímetro. (B) Mesmo camundongo na $19^{\mathrm{a}}$ semana de aplicação do TPA, observar ausência do tumor medido na foto anterior. Barra $=4 \mathrm{~cm}$.

\subsubsection{Tamanho dos tumores}

O diâmetro dos tumores dos animais tratados foi medido por paquímetro antes e depois da TFD, considerando os dois períodos experimentais de 24 horas e 15 dias. Os tumores dos animais controles foram medidos no último dia de aplicação do TPA (antes) e no dia do abate dos camundongos (depois). Nos grupos controles não ocorreram diferenças significativas no tamanho dos tumores antes e após o abate dos animais $(\mathrm{CEC}+24 \mathrm{~h}=4,94 \pm$ 1,21 antes; 5,31 \pm 1,60 depois; $P=0,170)$ e $(\mathrm{CEC}+15 \mathrm{~d}=8,25 \pm 5,32$ antes; 8,62 \pm 4,27 depois; $P=0,74)$. Nos grupos tratados com TFD ocorreram diminuições significativas no tamanho do diâmetro dos tumores $(\mathrm{CEC}+\mathrm{TFD}+24 \mathrm{~h}=4,94 \pm 1,29$ antes, 4,31 \pm 1,31 depois, $P=0,01)$ e $(\mathrm{CEC}+\mathrm{TFD}+15 \mathrm{~d}=5,75 \pm 3,00$ antes, 5,12 $\pm 3,44$ depois, $P=0,03)$. Os resultados estão apresentados na Figura 10. 


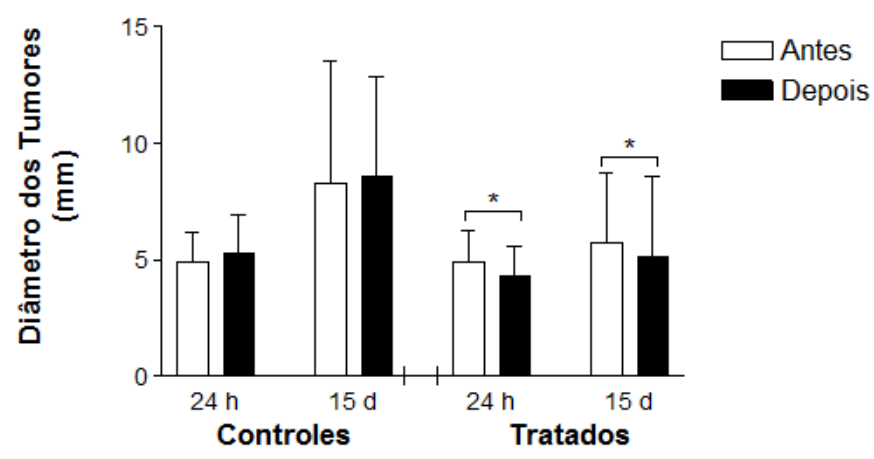

Figura 10 - Diâmetro dos tumores (mm) nos grupos experimentais. Grupos controles (CEC+24 h e CEC+15 d) os tumores foram medidos no último dia de aplicação do TPA (antes) e no dia do abate (depois), respeitando os dois períodos 24 horas e 15 dias. Grupos tratados (CEC+TFD+24 h e CEC+TFD+15 d) os tumores foram medidos antes e depois da TFD, considerando os períodos experimentais de 24 horas e 15 dias. Os dados estão expressos como média e desvio padrão. Resultados significativos representados por $*(P<0,05)$, Teste $\mathrm{t}$ de Student pareado $(\mathrm{n}=8)$.

\subsubsection{Alterações morfológicas após TFD}

As alterações macroscópicas dos tumores após a TFD foram acompanhadas por fotografias. Diferenças em relação aos tempos de 24 horas e 15 dias nos tumores tratados não foram evidentes, as diferenças antes e após a TFD estavam mais relacionadas ao tamanho das lesões, tumores pequenos apresentaram um aspecto necrosado, tumores grandes mostraram aspecto ulcerado. Poucas alterações macroscópicas foram observadas nas peles sadias tratadas após 24 horas, entretanto, após 15 dias, a maioria dos animais sadios tratados apresentaram ulcerações na pele (Figura 11). 

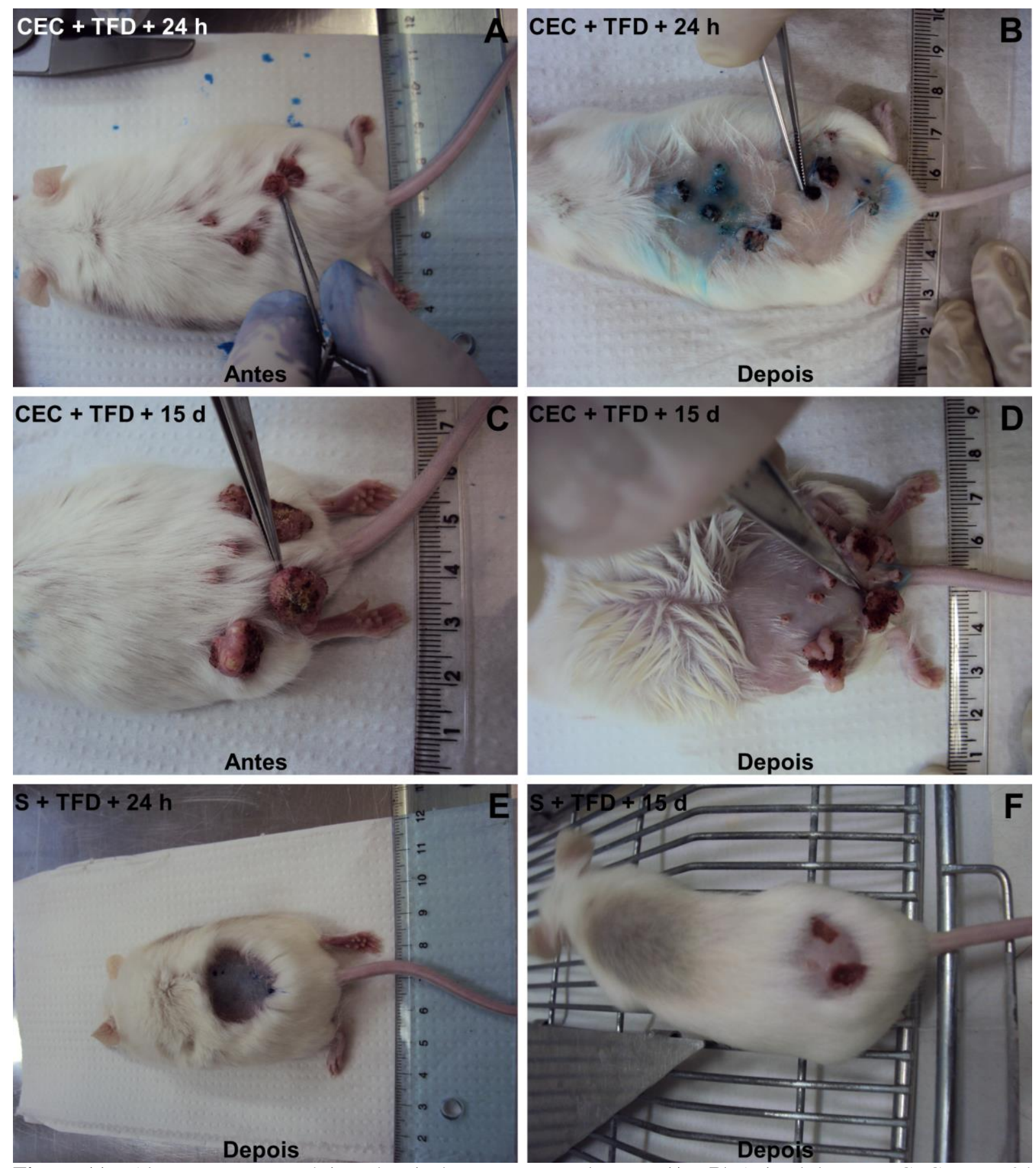

Figura 11 - Alterações macroscópicas depois do tratamento pela TFD. (A e B) Animal do grupo CEC+TFD+24 $\mathrm{h}$ antes e depois da TFD, respectivamente. Observar que o tumor indicado pela pinça após a TFD estava necrosado. (C e D) Animal do grupo CEC+TFD+15 d antes e depois da TFD, respectivamente. Notar que o tumor indicado pela pinça estava ulcerado após a TFD. (E) Animal sadio do grupo S+TFD+24 h. Poucas alterações macroscópicas foram observadas no grupo sadio 24 horas após a TFD. (F) Animal sadio do grupo S+TFD+15 d, notar que a pele apresentou ulceração 15 dias depois da TFD. 


\subsection{ASPECTOS MICROSCÓPICOS}

Os resultados dos aspectos microscópicos se referem à classificação histopatológica dos tumores de pele, avaliação histopatológica, depósito de colágeno, avaliação imunohistoquímica, avaliação de citocinas e de marcadores moleculares.

\subsubsection{Classificação histopatológica dos tumores}

Após tratamento pela TFD, as características histológicas dos tumores foram preservadas e foi possível classificá-las segundo gradação proposta por Broders (1921). A avaliação histopatológica indicou que dos 55 tumores colhidos para esta análise, 65,45\% foram positivos ao CEC $(\mathrm{n}=36)$. O restante das amostras indicaram lesões pré-neoplásicas, em que 16,36\% foram classificadas como CEC in situ e 18,18\% como papilomas. As amostras positivas ao CEC foram classificadas em: $75 \%$ bem diferenciadas, $16,67 \%$ moderadamente diferenciadas e $8,33 \%$ pouco diferenciadas. Nas amostras congeladas que foram previamente preservadas em RNA later $^{\circledR}$ ou diretamente em nitrogênio líquido para a técnica de RT-PCR em tempo real, no momento anterior à extração do RNA foi separado um fragmento de cada amostra para o exame histopatológico. A integridade tecidual ficou um pouco comprometida devido ao congelamento, portanto, foi possível classificar esses tumores. Das 38 amostras de tumores colhidas para essa análise, 52\% dos tumores foram positivos ao CEC $(n=20)$, todos classificados como bem diferenciados.

O exame histopatológico demonstrou que os tumores positivos ao CEC apresentaram na derme invasão neoplásica de células epiteliais escamosas arranjadas em ninhos contendo queratinização central evidente, denominadas pérolas córneas, sustentadas por um moderado à abundante estroma colagenoso. Estas células apresentaram citoplasma eosinofílico de contornos indefinidos, núcleo ovalado e nucléolo evidente. A maioria das amostras apresentou estrutura epitelial na configuração papilar e/ou lençóis sólidos. Invasão angiolinfática e infiltração perineural não foram detectadas.

Nos CECs bem diferenciados (Figura 12A) o pleomorfismo celular e o índice mitótico foram discretos, figuras de mitoses típicas e atípicas foram observadas. Ao redor das células neoplásicas foi observado infiltrado inflamatório misto discreto a moderado composto por linfócitos, plasmócitos e neutrófilos. A epiderme exibiu acantose irregular, áreas de hiperqueratose ortoqueratótica e áreas de hiperqueratose paraqueratótica moderadas. 
Os CECs moderadamente diferenciados (Figura 12B) apresentaram pleomorfismo celular e índice mitótico discreto a moderado, com figuras de mitoses típicas e atípicas. Ao redor das células neoplásicas foi visto moderado a acentuado infiltrado inflamatório misto composto por linfócitos, plasmócitos e neutrófilos. A epiderme apresentou extensa área de ulceração associada a intenso infiltrado neutrofílico, detritos celulares e fibrina.

As amostras classificadas como CECs pouco diferenciadas (Figura 12C) mostraram na derme subjacente, proliferação neoplásica de células epiteliais escamosas arranjadas em ninhos sólidos, sustentadas por moderado estroma colagenoso. O pleomorfismo celular foi moderado a acentuado e apresentou anisocariose moderada. O índice mitótico foi moderado com figuras de mitoses típicas e atípicas. Ao redor das células neoplásicas foi observado acentuado infiltrado inflamatório misto composto por linfócitos, plasmócitos e neutrófilos. A epiderme apresentou discreta acantose. 

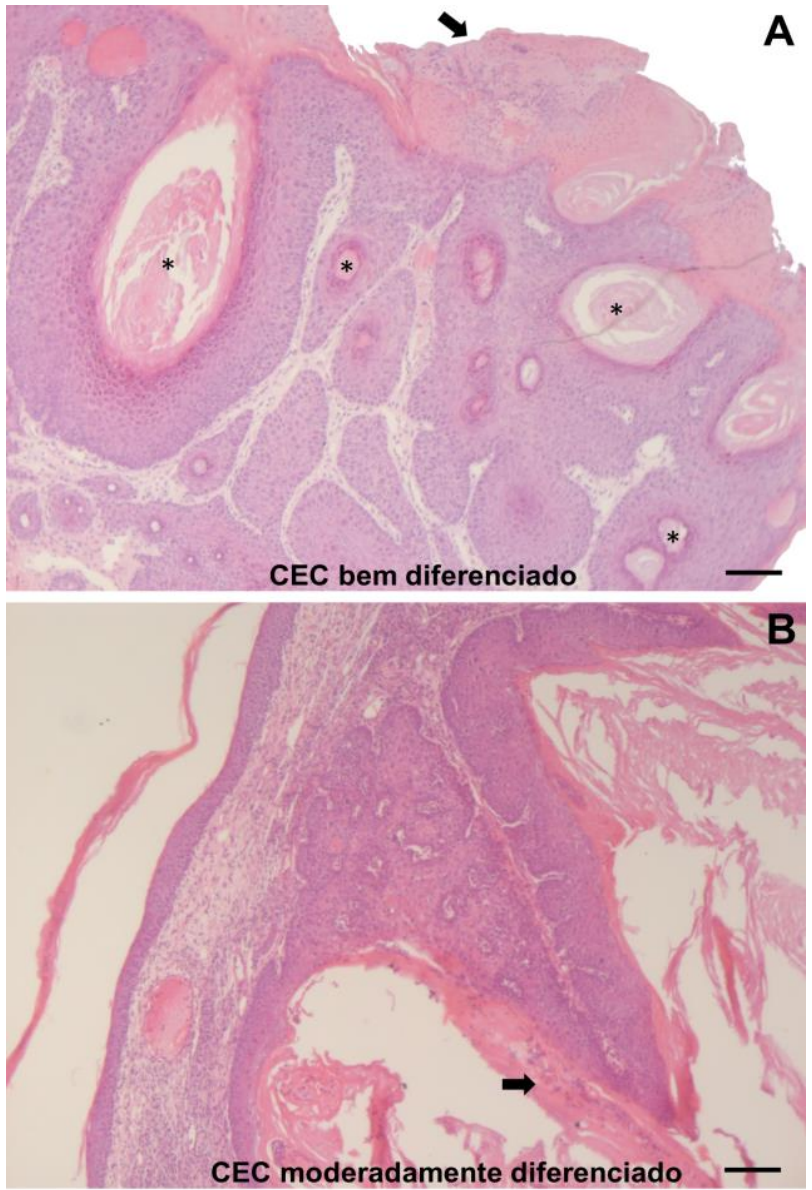

\section{$B$}

C

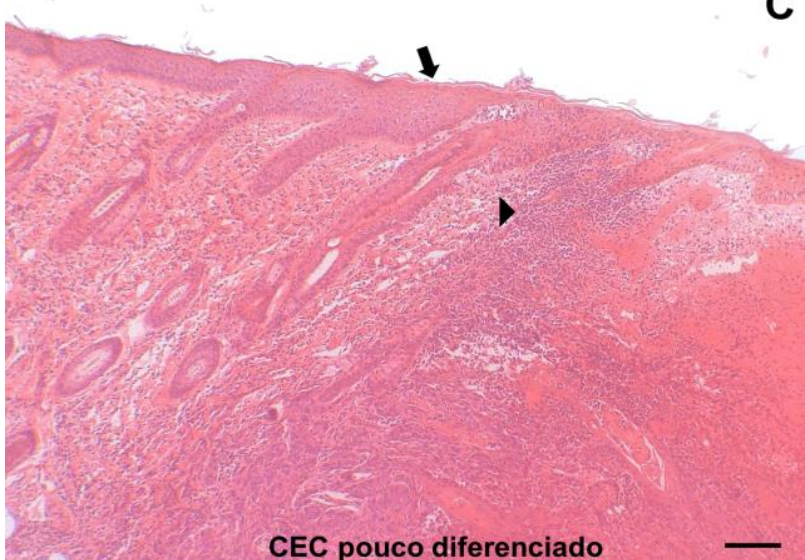

Figura 12 - Classificação Histopatológica dos Tumores. Grupos controles. Coloração HE. (A) CEC bem diferenciado, notar pérolas córneas (asteriscos), epitélio com acantose irregular e hiperqueratose paraqueratótica (seta). (B) CEC moderadamente diferenciado, comparado ao CEC bem diferenciado há menor formação de pérolas córneas, na epiderme acantose regular, hiperqueratose e áreas de ulceração são vistos (seta). (C) CEC pouco diferenciado, na epiderme nota-se discreta acantose (seta) e na derme, há um acentuado infiltrado inflamatório (cabeça de seta). Barra $=100 \mu \mathrm{m}$ para todas as fotomicrografias. 


\subsubsection{Avaliação histopatológica após a TFD}

No exame histopatológico foi observado que os grupos tratados, tanto de 24 horas como de 15 dias, não apresentaram diferenças marcantes comparados aos grupos controles correlacionados. Após o tratamento pela TFD ocorreu manutenção da integridade tecidual nos estratos epiteliais. Algumas amostras, tanto dos grupos controles como dos tratados, apresentaram ulceração no epitélio, associado a um infiltrado neutrofílico e detritos celulares. Não houve necrose nos grupos tratados, entretanto, evidências de alterações nucleares compatíveis com apoptose foram observadas. Na maioria das amostras, tanto controles como tratados, o estroma tumoral apresentou infiltrado inflamatório misto constituído por neutrófilos, linfócitos e plasmócitos (Figura 13). 

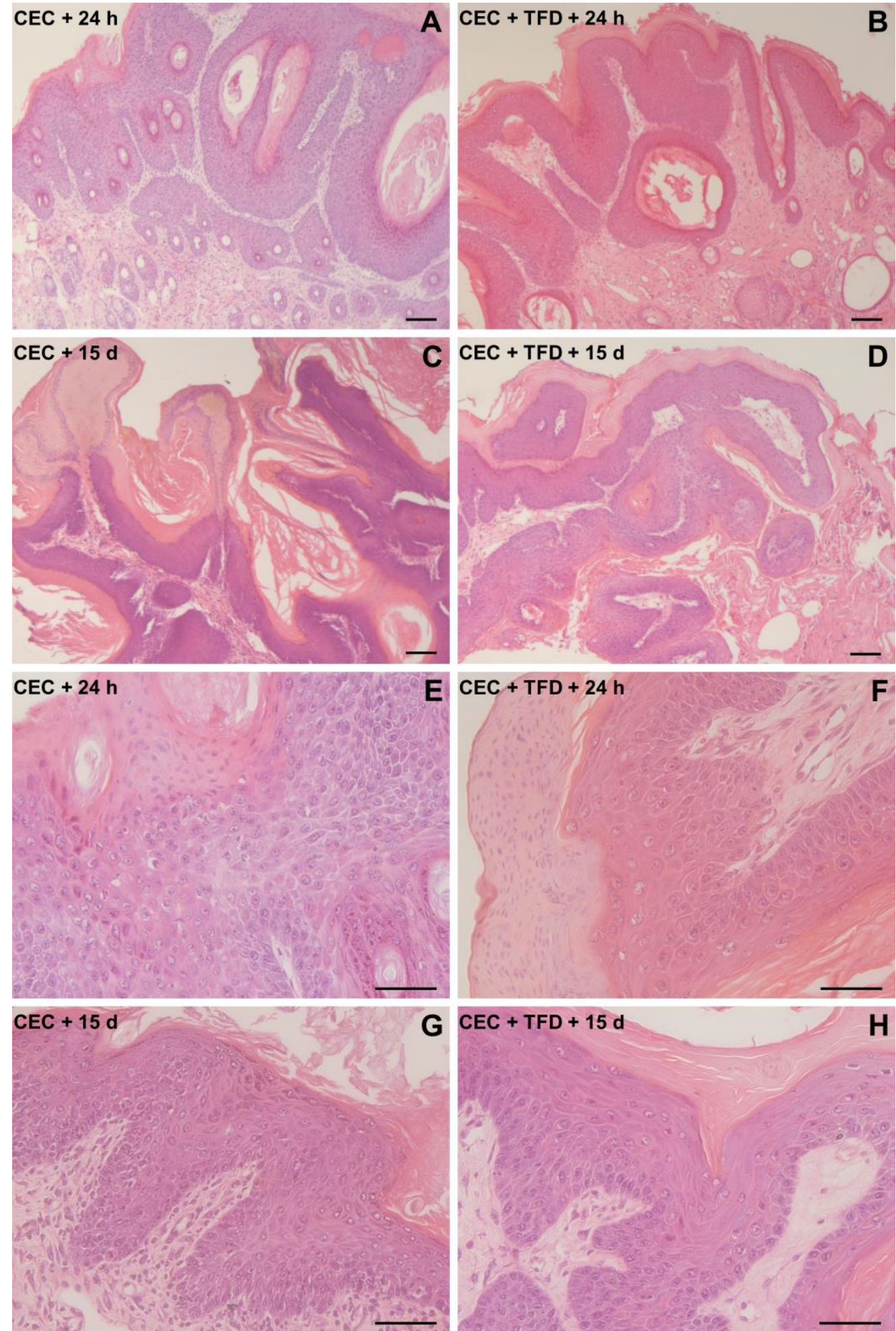

Figura 13 - Morfologia microscópica após a TFD dos grupos induzidos ao CEC em diferentes aumentos (A-D) Barra $=100 \mu \mathrm{m}$; (E-F) Barra $=50 \mu \mathrm{m}$. Coloração HE. (A e B) Respectivamente, grupo controle e tratado do período de 24 horas. Notar que a estrutura tecidual é semelhante nos dois grupos, com a presença de pérolas córneas, acantose e hiperqueratose. (C e D) Respectivamente, grupo controle e tratado do período de 15 dias. Não há diferenças marcantes na arquitetura tecidual entre os dois grupos. (E e F) Respectivamente, grupo controle e tratado do período de 24 horas. Observar que os epitélios mantém integridade, áreas de ulceração associada com infiltrado neutrofílico foram observadas, tanto nos grupos controles como nos grupos tratados. (G e H) Respectivamente, grupo controle e tratado do período de 15 dias. Notar que há integridade do tecido epidérmico e dérmico. 
Nos animais sadios sem tratamento (controle) a avaliação histopatológica indicou que a epiderme e a derme estavam íntegras, sem a presença de células neoplásicas e formação de infiltrado inflamatório. Na pele sadia tratada após 24 horas da TFD, poucas alterações foram observadas no epitélio, ocorreu desprendimento epitelial em poucos animais, pois a epiderme permaneceu íntegra, mas na derme e no tecido subcutâneo foi notado discreto infiltrado inflamatório neutrofílico distribuído de forma difusa pelo tecido. Além disso, as fibras colágenas pareciam mais distendidas quando comparadas com as fibras colágenas do controle, que estavam mais direcionadas e compactas. Na pele sadia tratada após 15 dias da TFD, a epiderme mostrou acantose e hiperqueratose ortoqueratótica, algumas das amostras apresentaram áreas de ulceração associadas a um infiltrado neutrofílico com detritos celulares e fibrina. $\mathrm{Na}$ derme e no tecido subcutâneo foi observado infiltrado inflamatório predominantemente linfoplasmocítico difuso, com raros neutrófilos; o infiltrado inflamatório geralmente estava associado com fibroblastos reativos e vasos sanguíneos neoformados (Figura 14).
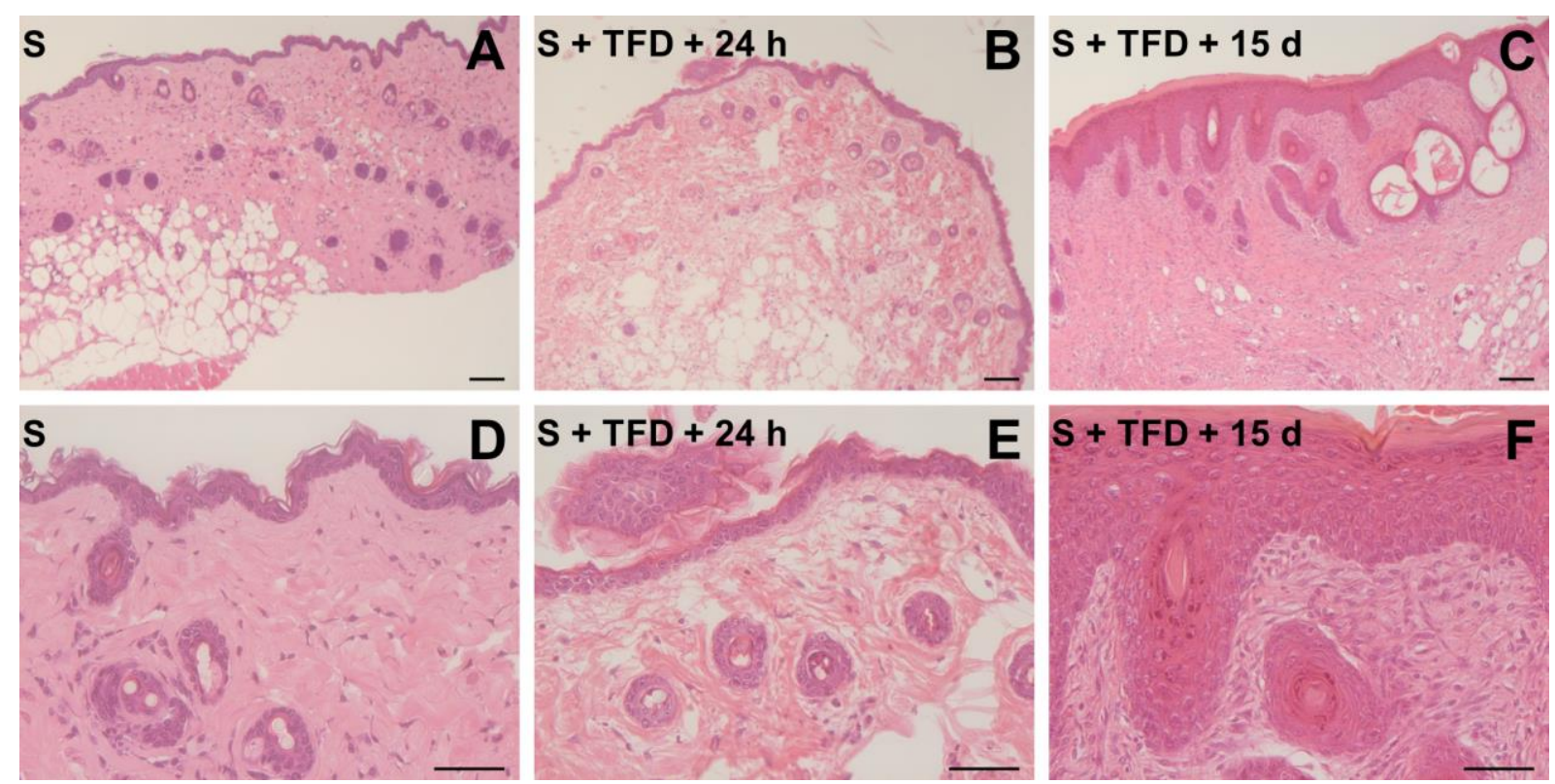

Figura 14 - Morfologia microscópica após a TFD dos grupos sadios em diferentes aumentos (A-C) Barra = 100 $\mu \mathrm{m}$ (D-F) Barra $=50 \mu \mathrm{m}$. Coloração HE. (A e D) Respectivamente, fotomicrografias em menor e maior aumento do grupo controle sadio. Notar a integridade da epiderme e derme. (B e E) Respectivamente, fotomicrografias em menor e maior aumento do grupo sadio tratado do período de 24 horas. Observe o desprendimento do epitélio e fibras colágenas dispersas. (C e F) Respectivamente, fotomicrografias em menor e maior aumento do grupo controle e tratado do período de 15 dias. Note as alterações no epitélio com hiperqueratose e acantose; na derme presença de fibroblastos reativos. 


\subsubsection{Avaliação do depósito de colágeno tipo I}

A avaliação morfológica das fibras colágenas nos grupos CECs tratados com TFD demonstrou que há discreta tendência no aumento dessas fibras dentro do estroma tumoral. Nos grupos sadios tratados foi observado que a TFD provocou desarranjo das fibras colágenas, alterações referentes à compactação e orientação dessas fibras. Nas peles tratadas as fibras colágenas estavam mais dispersas e a orientação não foi mais paralela à superfície, como observado no controle (Figura 15).

Para análise do colágeno intratumoral nos grupos CECs e o colágeno distribuído na derme na pele sadia, as lâminas coradas pela técnica histológica Picrosirius foram quantificadas automaticamente em programa de análise de imagem por análise colorimétrica. Após 24 horas do tratamento pela TFD, o grupo CEC tratado (CEC+TFD+24 h = 20,29 \pm $8,52)$ apresentou tendência no aumento do colágeno intratumoral quando comparado ao grupo controle $(\mathrm{CEC}+24 \mathrm{~h}=13,01 \pm 7,55)$, portanto, esse aumento não foi significativo $(P=0,19)$. No outro período analisado, de 15 dias, o grupo CEC tratado (CEC+TFD+15 d = 28,49 \pm 12,39) também apresentou aumento no depósito de colágeno intratumoral comparado ao grupo controle $(\mathrm{CEC}+15 \mathrm{~d}=22,54 \pm 12,26)$, portanto, sem diferença estatística $(P=0,46)$.

Ao contrário dos resultados obtidos nos grupos induzidos ao CEC, os grupos sadios apresentaram diminuição significativa no depósito de colágeno na derme, nos dois períodos avaliados. No grupo sadio tratado $(S+T F D+24 h=72,67 \pm 6,85)$, a redução do colágeno foi de $18,02 \%$ quando comparado ao controle $(\mathrm{S}=88,65 \pm 4,96), P=0,0029$. No grupo sadio tratado $(\mathrm{S}+\mathrm{TFD}+15 \mathrm{~d}=63,75 \pm 3,85)$ a redução foi de $28,09 \%$ em relação ao controle, $P=$ 0,0001 . 

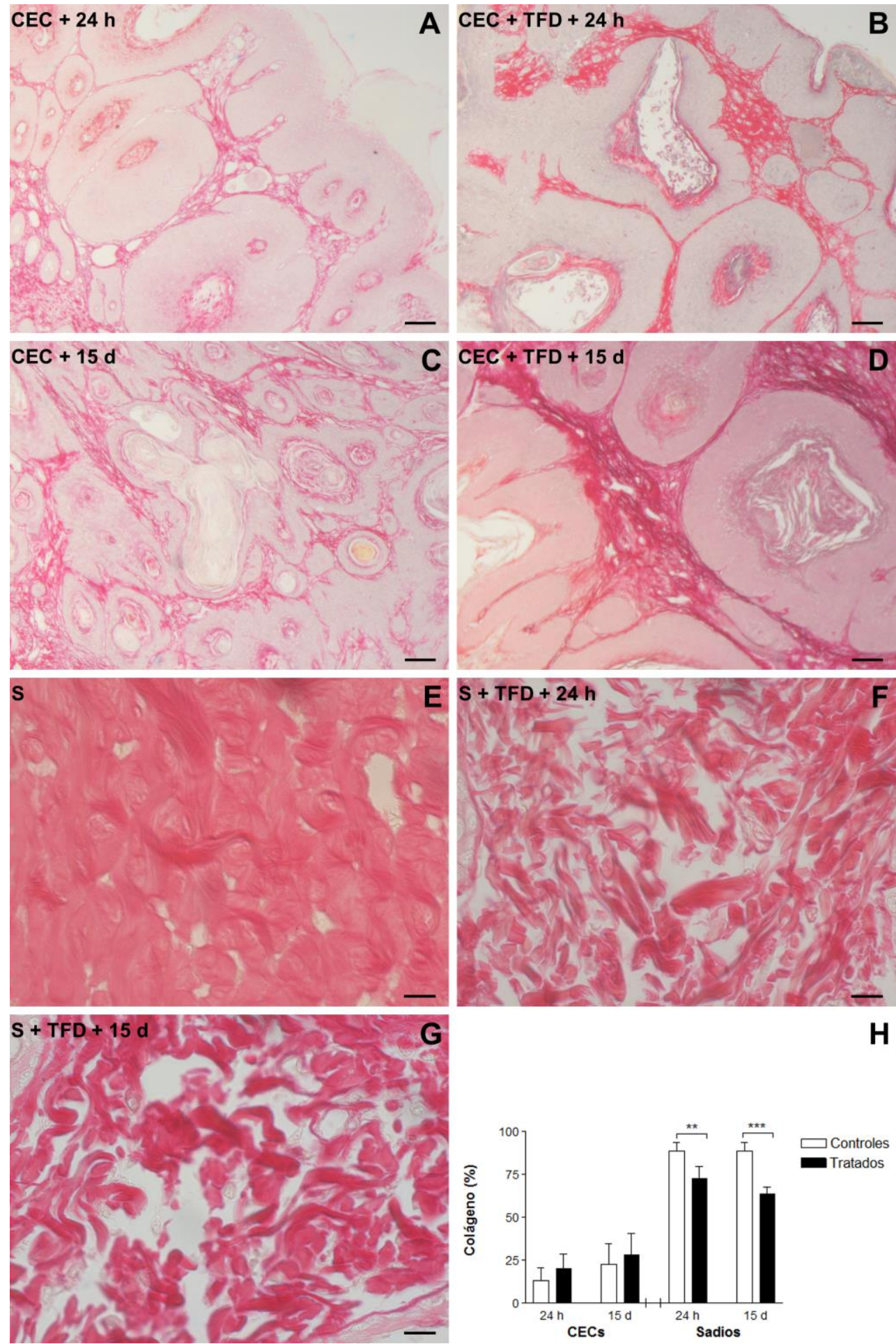

Figura 15 - Morfologia das fibras colágenas dos grupos induzidos ao CEC e grupos sadios. Coloração Picrosírius. (A e C) Grupos controles de animais induzidos ao CEC, período de 24 horas e 15 dias, respectivamente. (B e D) Grupos tratados de animais induzidos ao CEC, período de 24 horas e 15 dias, respectivamente. (A-D) Barra $=50 \mu \mathrm{m}$. (E) Grupo controle dos animais sadios. (F) Grupo tratado dos animais sadios, período de 24 horas. (G) Grupo tratado de animais sadios, período de 15 dias. Observar o desarranjo das fibras colágenas dos animais sadios tratados. (E-G) Barra $=20 \mu \mathrm{m}$. (H) Porcentagem da área ocupada pelo colágeno em relação à área total do campo $\left(90.220 \mathrm{~m}^{2}\right)$ no tecido tumoral e $\left(14.435,2 \mu \mathrm{m}^{2}\right)$ no tecido sadio. Os dados estão representados por média e desvio padrão. $\left.{ }^{*}\right)$ diferença significante $(P<0,05)$ em relação ao grupo controle, teste não pareado $t$-Student $(\mathrm{n}=5)$. 


\subsubsection{Imuno-histoquímica para PCNA}

A avaliação imuno-histoquímica do antígeno PCNA demonstrou expressão no núcleo das células localizadas com predomínio no estrato basal e espinhoso da epiderme, cuja marcação mostrou variação na intensidade da coloração pela reação com o DAB, passando de um tom marrom ao acastanhado. Algumas amostras a intensidade da marcação pelo PCNA foi muito forte, por isso causou reação de fundo, no entanto, isso não atrapalhou a identificação de núcleos positivos.

A avaliação do índice de células PCNA-positivas demonstrou que após 24 horas o grupo CEC tratado $(\mathrm{CEC}+\mathrm{TFD}+24 \mathrm{~h}=50,24 \pm 6,90)$ teve redução na marcação pelo PCNA comparado ao grupo controle $(\mathrm{CEC}+24 \mathrm{~h}=55,28 \pm 21,36)$, portanto, essa redução não foi significativa $(P=0,062)$. No período de 15 dias, o grupo CEC tratado $(\mathrm{CEC}+\mathrm{TFD}+15 \mathrm{~d}=$ $45,28 \pm 10,18)$ apresentou diminuição significativa no índice de células positivas ao PCNA comparado ao controle (CEC $+15 \mathrm{~d}=67,16 \pm 2,36), P=0,0016$.

O grupo sadio tratado no período de 24 horas $(\mathrm{S}+\mathrm{TFD}+24 \mathrm{~h}=36,72 \pm 17,72)$ diminuiu a marcação ao PCNA comparado ao controle $(S=41,12 \pm 11,31)$, a redução não foi significativa $(P=0,65)$, portanto, quando o mesmo grupo controle $\mathrm{S}$ foi comparado ao grupo do período de 15 dias $(\mathrm{S}+\mathrm{TFD}+15 \mathrm{~d}=18,32 \pm 10,40)$ redução significativa no índice de positividade ao PCNA $(P=0,0106)$ foi verificada. Os resultados estão apresentados na Figura 16. 

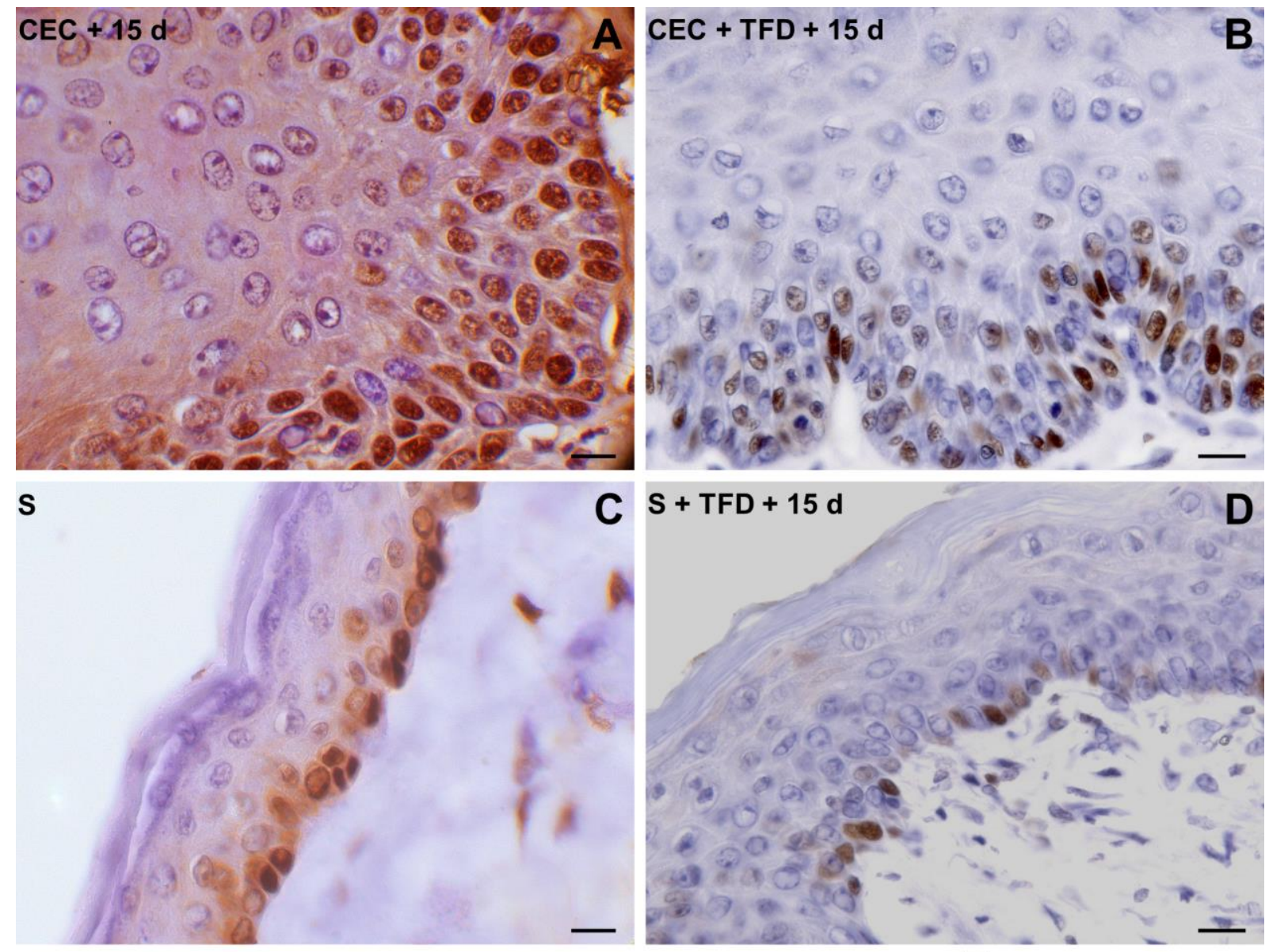

\section{$\mathbf{E}$}

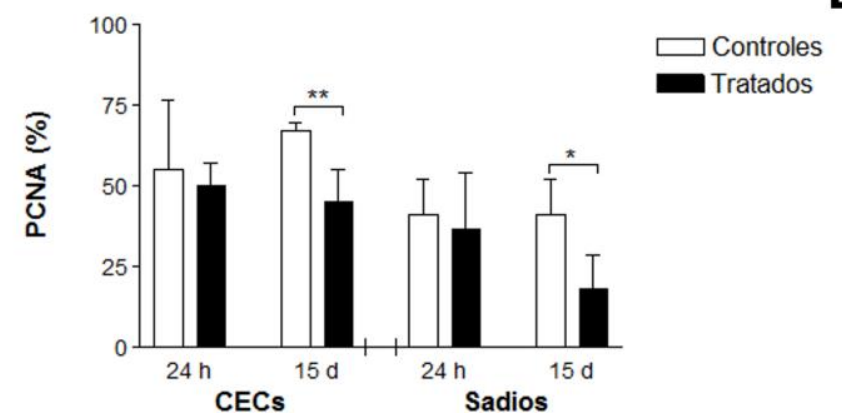

Figura 16 - Fotomicrografias representativas da imunomarcação pelo PCNA. Notar núcleos marcados em marrom pela reação com o DAB. (A e B) Respectivamente, grupo controle e tratado de animais induzidos ao CEC, período de 15 dias (C e D) Respectivamente, grupo controle e tratado de animais sadios, período de 15 dias. Barra para todas as fotomicrografias $=10 \mu \mathrm{m}$. (E) Índice de positividade ao PCNA (\%). Os dados estão representados por média e desvio padrão. (*) $P<0,05$ em relação ao grupo controle, $\left.{ }^{* *}\right) P<0,01$ em relação ao grupo controle, teste não pareado $t$-Student $(\mathrm{n}=5)$.

\subsubsection{Avaliação dos marcadores de apoptose pelo TUNEL e Caspase 3 clivada}

\subsubsection{Técnica de TUNEL}

A técnica de TUNEL reconhece a fragmentação in situ do DNA, cuja identificação nas células é nuclear. As células positivas à reação de TUNEL apresentaram localização dispersa 
pelos estratos da epiderme. A marcação mostrou grande variação na intensidade da coloração pela reação com o DAB (Figura 17).

O maior índice obtido pela reação ao TUNEL foi do grupo sadio tratado (S+TFD+15 d $=73,08 \pm 12,18)$, ao passo que, o menor índice foi encontrado no grupo CEC controle $(\mathrm{CEC}+24 \mathrm{~h}=41,00 \pm 24,41)$. Todos os grupos tratados quando comparados com os respectivos controles apresentaram tendência no aumento do índice de positividade (\%) ao TUNEL, entretanto, nenhum dos grupos apresentou resultados significativos $(P>0,05)$. 

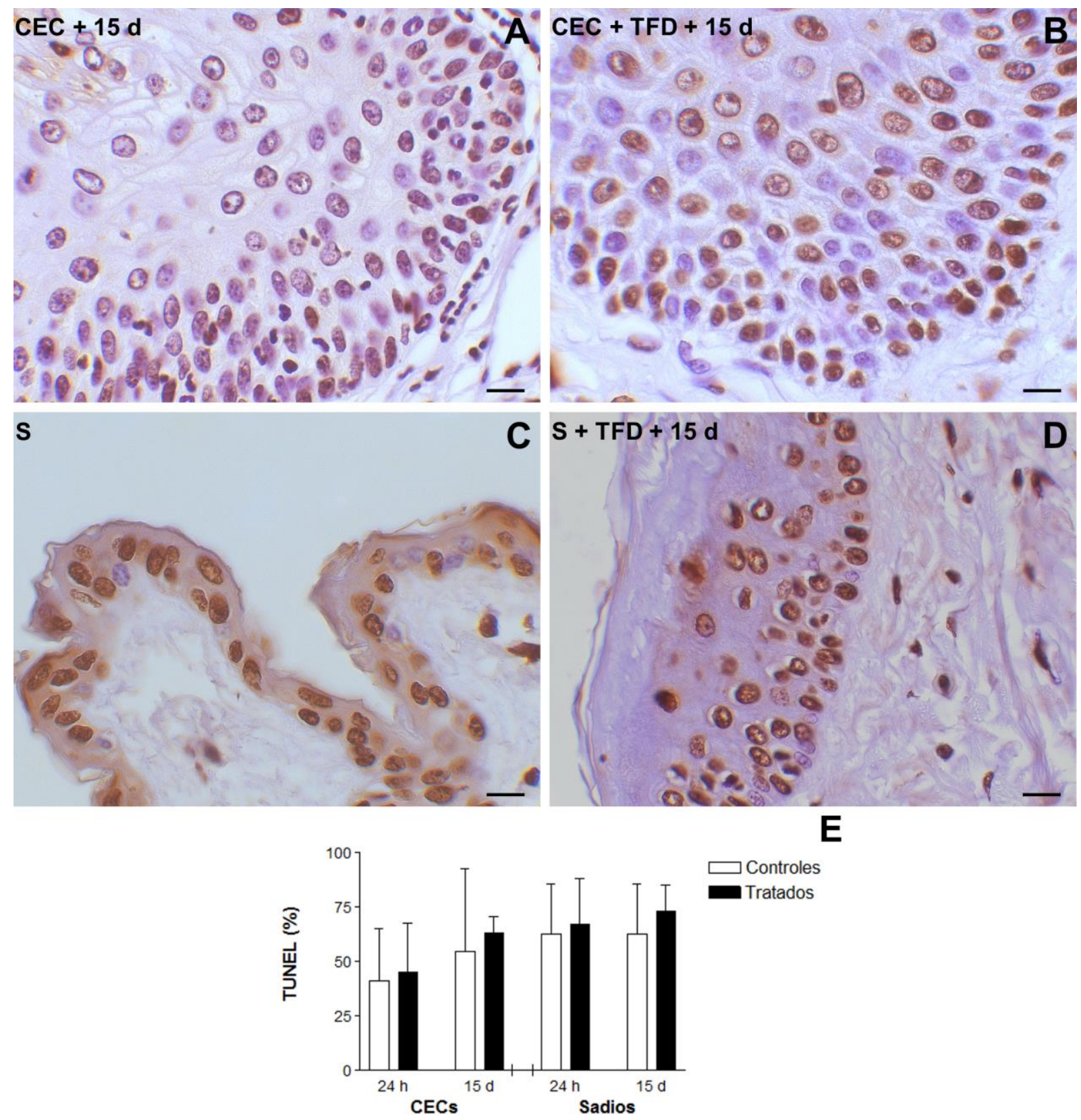

Figura 17 - Fotomicrografias representativas da técnica de TUNEL. Notar núcleos marcados em marrom pela reação com o DAB. (A e B) Respectivamente, grupo controle e tratado de animais induzidos ao CEC, período de 15 dias (C e D) Respectivamente, grupo controle e tratado de animais sadios, período de 15 dias. Barra para todas as fotomicrografias $=10 \mu \mathrm{m}$. (E) Índice de células positivas ao TUNEL (\%). Os dados estão representados por média e desvio padrão. Não ocorreu diferença significativa $(P>0,05)$ dos grupos tratados em relação aos controles, teste não pareado $t$-Student $(\mathrm{n}=5)$.

\subsubsection{Imuno-histoquímica para Caspase 3 clivada}

A avaliação da expressão da caspase 3 clivada foi realizada pela técnica de imunohistoquímica. Esta caspase quando clivada é ativada nas primeiras fases da apoptose. O perfil de expressão da caspase 3 clivada foi citoplasmática em todas as amostras avaliadas, mostrou marcação difusa pelos estratos basal e espinhoso da epiderme (Figura 18). 
A quantificação de células positivas à caspase 3 clivada demonstrou que a expressão deste antígeno foi baixa na maioria dos grupos. O grupo CEC tratado no período de 24 horas $(\mathrm{CEC}+\mathrm{TFD}+24 \mathrm{~h}=0,28 \pm 0,11)$ apresentou discreto aumento no índice de células marcadas comparada ao grupo controle $(\mathrm{CEC}+24 \mathrm{~h}=0,12 \pm 0,27)$, a comparação entre os grupos não foi significativa $(P=0,25)$. O grupo CEC tratado no período de 15 dias $(\mathrm{CEC}+\mathrm{TFD}+15 \mathrm{~d}=$ $1,28 \pm 1,17)$ comparado ao seu controle $(\mathrm{CEC}+15 \mathrm{~d}=1,52 \pm 1,12)$ não apresentou diferença significativa pela marcação da caspase $3(P=0,74)$.

O grupo sadio tratado no período de 24 horas após TFD $(\mathrm{S}+\mathrm{TFD}+24 \mathrm{~h}=39,92 \pm$ $19,49)$ apresentou aumento significativo $(P>0,0019)$ na expressão de caspase 3 em relação ao grupo controle $(S=0,32 \pm 0,30)$. No período de 15 dias após a TFD, o grupo sadio tratado $(\mathrm{S}+\mathrm{TFD}+15 \mathrm{~d}=24,68 \pm 22,23)$ apresentou aumento significativo $(P=0,039)$ na expressão de caspase 3 quando comparado ao controle.
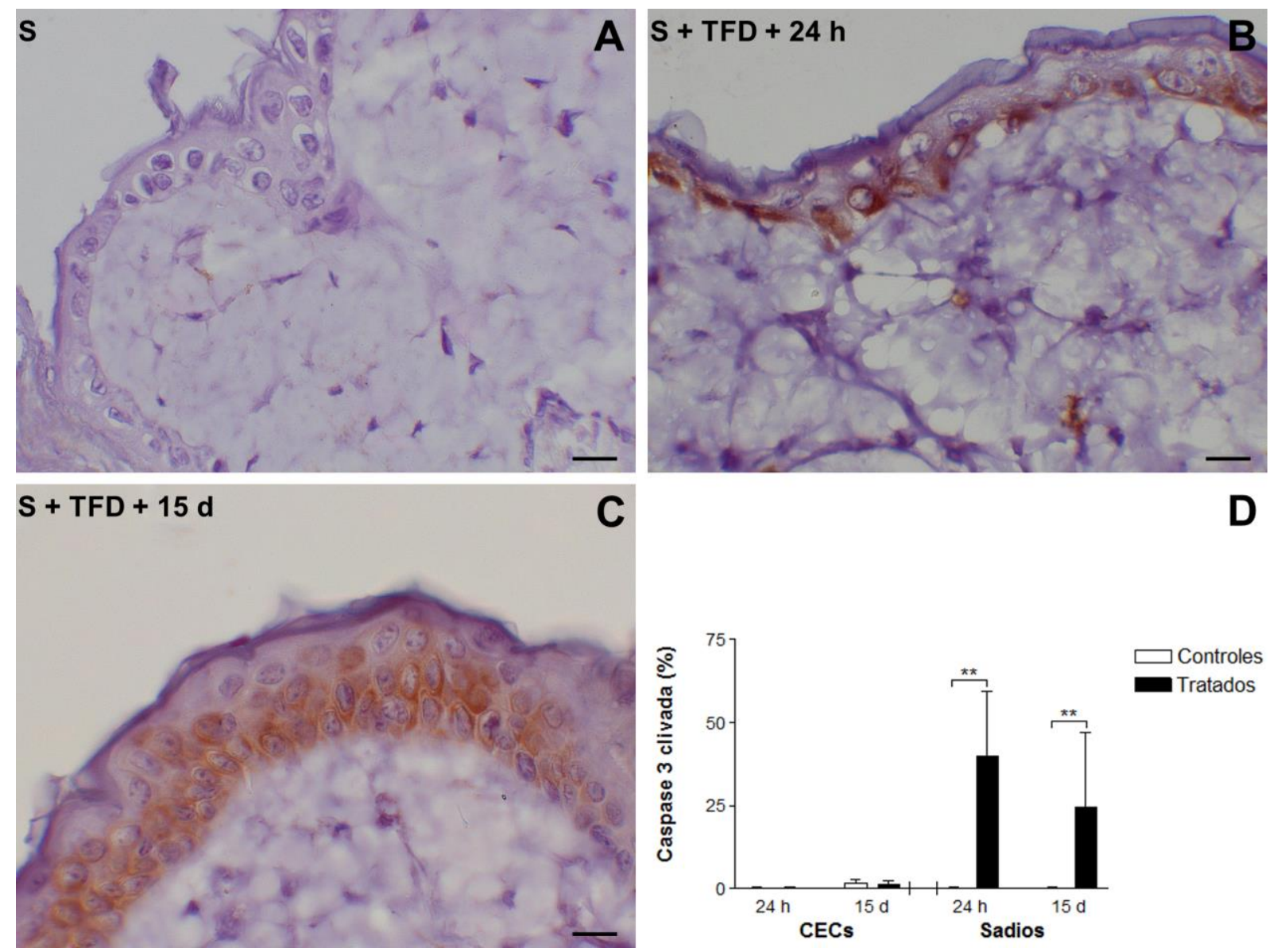

Figura 18 - Fotomicrografias representativas da marcação imuno-histoquímica pela caspase 3 clivada. Notar o citoplasma das células marcado em marrom pela reação com o DAB. (A) Grupo controle de animais sadios (B) Grupo tratado de animais sadios, período de 24 horas. (C) Grupo tratado de animais sadios, período de 15 dias. Barra para todas as fotomicrografias $=10 \mu \mathrm{m}$. (D) Índice de células positivas à caspase 3 clivada (\%). Os dados estão representados por média e desvio padrão. (**) $P<0,01$ em relação ao grupo controle, teste não pareado $t$ Student $(\mathrm{n}=5)$. 


\subsubsection{Avaliação do sistema imune celular pela marcação imuno-histoquímica de CD8 e níveis plasmáticos das citocinas TNF-alpha, IL-1Beta e IL-2 pela técnica de ELISA}

\subsubsection{Imuno-histoquímica para CD8}

Células positivas ao CD8 foram observadas em todas as amostras controles e tratadas, de forma esporádica, nas áreas próximas à junção dermo-epidérmica, no epitélio e na parede dos vasos sanguíneos. A detecção deste antígeno foi nuclear na maioria das amostras e poucas apresentaram padrão citoplasmático. Qualitativamente não foi notada diferença na expressão de CD8 entre amostras tratadas e controles, tanto nos grupos induzidos ao CEC como nos animais sadios, nos dois períodos avaliados (Figura 19).
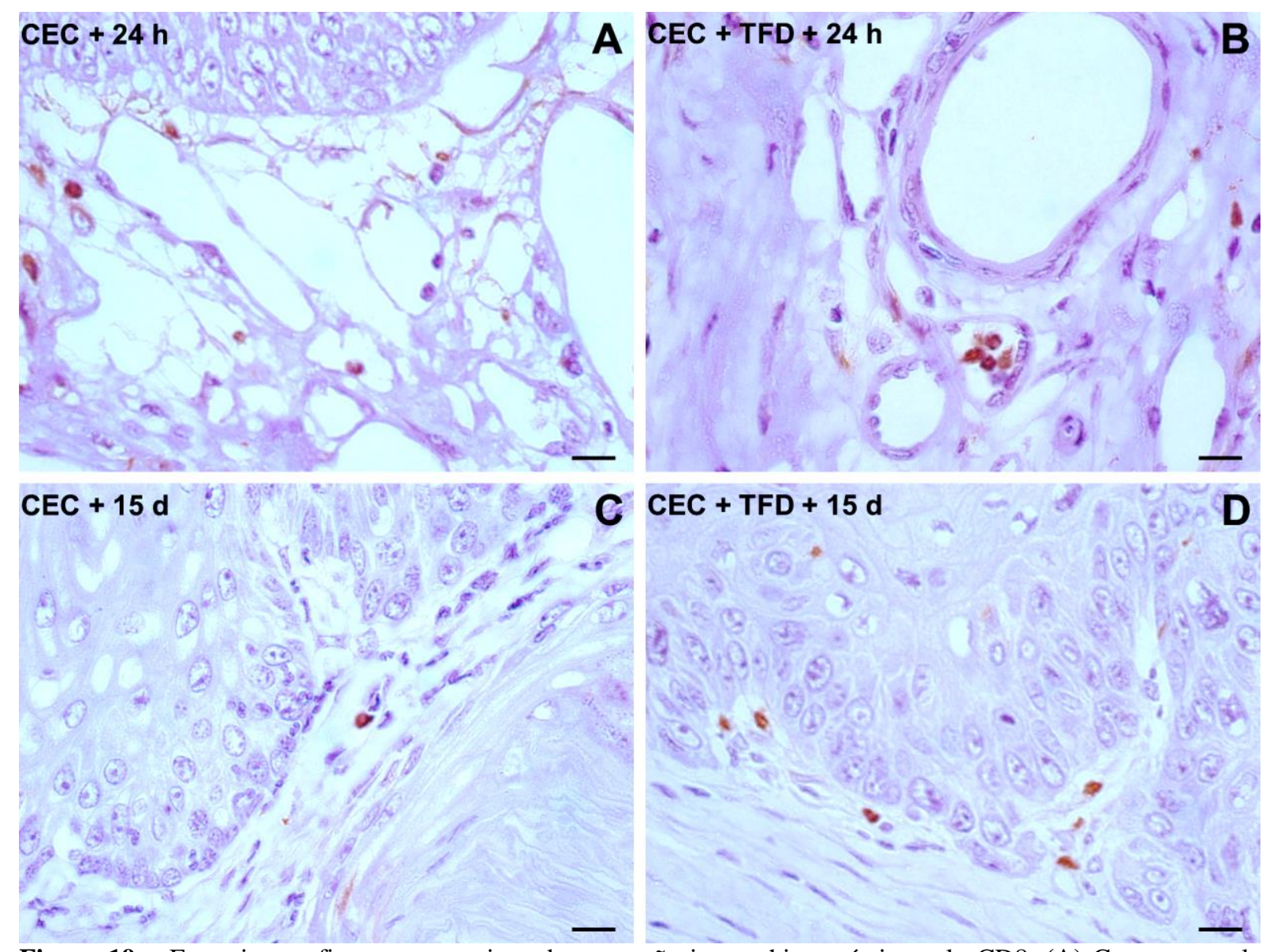

Figura 19 - Fotomicrografias representativas da marcação imuno-histoquímica pelo CD8. (A) Grupo controle de animais induzidos ao CEC, período de 24 horas. Notar núcleos positivos sob o epitélio. (B) Grupo tratado de animais induzidos ao CEC, período de 24 horas. Notar núcleos positivos dentro de um vaso sanguíneo. (C) Grupo controle de animais induzidos ao CEC, período de 15 dias. (D) Grupo tratado de animais induzidos ao CEC, período de 15 dias. Notar células positivas localizadas na junção dermo-epidérmica. Barra para todas as fotomicrografias $=10 \mu \mathrm{m}$. 


\subsubsection{Técnica de ELISA para avaliação de citocinas}

A quantificação de TNF- $\alpha$ foi baixa na maioria dos grupos experimentais controles e tratados (Figura 20A). Os valores obtidos foram validados pela curva padrão e pelo controle cedido no kit, cujo valor poderia variar entre 82 e 136 pg/mL. O controle de referência do ensaio para o TNF- $\alpha$ ficou dentro do parâmetro estabelecido $(131,04 \mathrm{pg} / \mathrm{mL})$. O grupo sadio tratado no período de 15 dias $(\mathrm{S}+\mathrm{TFD}+15 \mathrm{~d}=29,05 \pm 21,15)$ apresentou aumento significativo $(P<0,015)$ em relação ao controle $(S=0,00 \pm 0,01)$.

A quantificação de IL-1 $\beta$ nos grupos experimentais foi validada pela curva padrão e pelo controle no kit, cujo valor poderia variar entre 86 e 144 pg/mL. O controle de referência do ensaio ficou dentro do parâmetro estabelecido $(90,00 \mathrm{pg} / \mathrm{mL})$. O grupo CEC tratado de 24 horas $(\mathrm{CEC}+\mathrm{TFD}+24 \mathrm{~h}=262,71 \pm 55,25)$ apresentou aumento na concentração desta citocina quando comparada ao grupo controle $(\mathrm{CEC}+24 \mathrm{~h}=220,38 \pm 141,80)$, portanto, este aumento não foi significativo $(\mathrm{p}=0,55)$. No grupo tratado de 15 dias $(\mathrm{CEC}+\mathrm{TFD}+15 \mathrm{~d}=$ $295,25 \pm 118,06)$ o aumento na concentração de IL-1 $\beta$ foi significativo ( $p=0,0007)$ quando comparado ao grupo controle $(\mathrm{CEC}+15 \mathrm{~d}=11,80 \pm 10,13)$. Ao contrário dos grupos CECs, nos grupos sadios, a concentração de IL-1 $\beta$ foi maior no grupo controle $(S=109,48 \pm 93,40)$ do que nos grupos tratados nos dois períodos avaliados, entretanto, quando o grupo controle foi comparado com os grupos tratados, nenhum dos dois períodos mostrou diminuição significativa $(\mathrm{S}+\mathrm{TFD}+24 \mathrm{~h}=48,21 \pm 27,24, P=0,19 ; \mathrm{S}+\mathrm{TFD}+15 \mathrm{~d}=87,95 \pm 39,29, P=$ 0,64). Esse resultado está demonstrado na Figura 20B.

Os valores obtidos na quantificação de IL-2 foram validados pela curva padrão e pelo controle fornecido pelo kit, cujo valor poderia variar entre 93 e $155 \mathrm{pg} / \mathrm{mL}$. O controle de referência do ensaio da IL-2 ficou dentro do parâmetro estabelecido (146,53 pg/mL). No período de 24 horas, o grupo tratado CEC apresentou aumento significativo na concentração de IL-2 $(\mathrm{CEC}+\mathrm{TFD}+24 \mathrm{~h}=200,76 \pm 77,63)$ quando comparado ao controle $(\mathrm{CEC}+24 \mathrm{~h}=$ $0,00 \pm 0,01) P=0,0004$. O grupo tratado CEC de 15 dias também apresentou aumento significativo em relação ao seu controle (CEC+TFD+15 d = 120, $18 \pm 48,59$; CEC+15 d = $0,00 \pm 0,01 ; P=0,0006)$. Nos grupos sadios tratados ocorreu redução na concentração desta citocina quando comparados ao controle $(S=76,83 \pm 83,32)$, no período de 24 horas $(\mathrm{S}+\mathrm{TFD}+24 \mathrm{~h}=41,68 \pm 26,86 ; P=0,39)$ e no período de 15 dias $(\mathrm{S}+\mathrm{TFD}+15 \mathrm{~d}=6,27 \pm$ 6,09; $P=0,95)$, portanto a diminuição não foi significativa. Os dados estão mostrados na Figura 20C. 

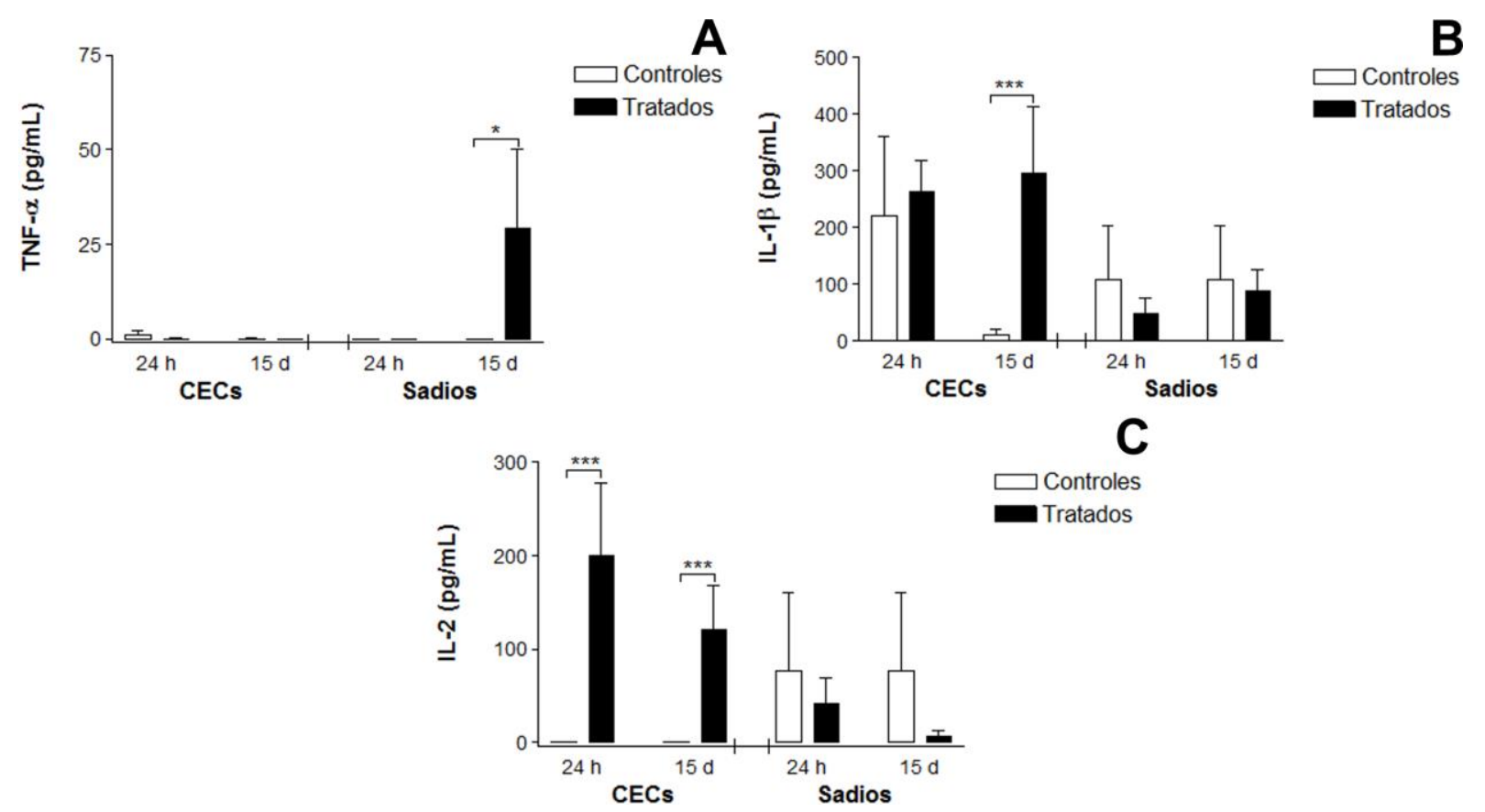

Figura 20 - Níveis plasmáticos de citocinas (pg/mL). (A) Avaliação do TNF- $\alpha$. (B) Avaliação do IL-1 $\beta$. (C) Avaliação da IL-2. Os dados estão representados por média e desvio padrão. (*) $P<0,05, P<0,001$ em relação ao grupo controle, teste não pareado $t$-Student $(\mathrm{n}=5)$.

\subsubsection{Avaliação da vascularização pela marcação imuno-histoquímica do fator de von Willebrand (fvW)}

A expressão do fvW apresentou marcação na parede das células endoteliais. Nos grupos CECs alguns vasos se encontravam dentro da área tumoral, sob o epitélio e nas áreas de tecido adiposo. Nos animais sadios, os vasos marcados pelo fvW estavam localizados na área profunda da derme ou entre os adipócitos da hipoderme (Figura 21).

Os vasos marcados por esse antígeno foram contados por área. O número de vasos marcados aumentou no grupo CEC tratado no período de 24 horas (CEC+TFD+24 h = 49,20 $\pm 11,65)$ quando comparado ao controle $(\mathrm{CEC}+24 \mathrm{~h}=30,60 \pm 15,81)$, portanto, esse aumento não foi significativo $(P=0,06)$. No grupo CEC tratado de 15 dias $(C E C+T F D+15 \mathrm{~d}=42,20 \pm$ 17,99) não ocorreu diferença significativa em relação ao controle $(C E C+15 d=42,20 \pm$ 21,28). Nos grupos sadios, no período de 24 horas após o tratamento ( $\mathrm{S}+\mathrm{TFD}+24 \mathrm{~h}=4,00 \pm$ 1,87) não ocorreu diferença significativa no número de vasos marcados quando comparado ao controle $(S=3,80 \pm 2,59$. Ao comparar o grupo controle $(S)$ com o grupo tratado no período de 15 dias foi observado aumento significativo no número de vasos marcados pelo fvW $(\mathrm{S}+\mathrm{TFD}+15 \mathrm{~d}=35,80 \pm 26,32 ; P=0,026)$. 

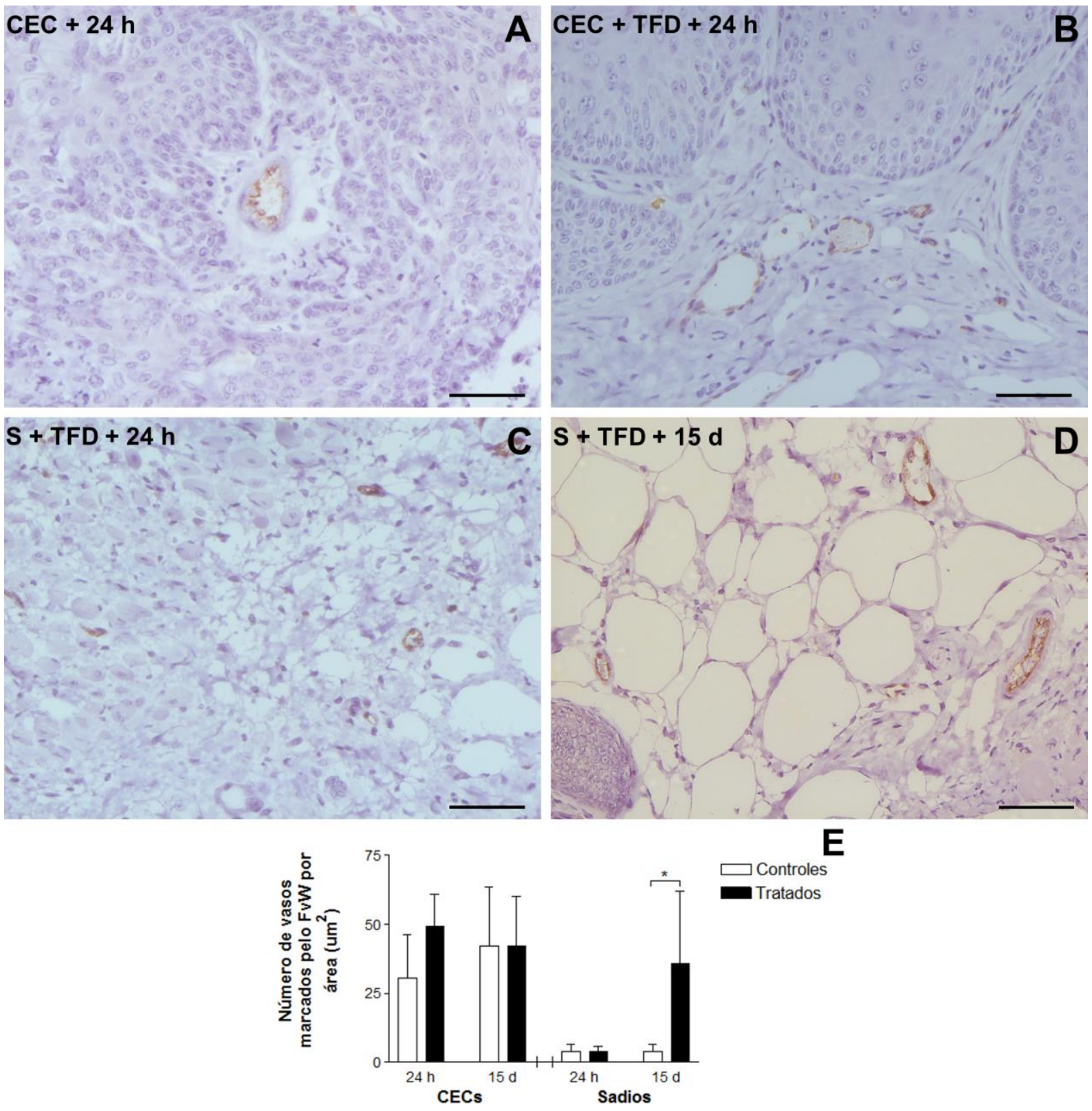

Figura 21 - Fotomicrografias representativas da marcação imuno-histoquímica pelo fator de von Willebrand (fvW). Notar vasos marcados em marrom pela reação com o DAB. (A) Grupo controle de animais induzidos ao CEC, período de 24 horas. Notar um vaso marcado dentro da área tumoral. (B) Grupo tratado de animais induzidos ao CEC, período de 24 horas. Os vasos estão localizados sob o epitélio. (C) Grupo tratado de animais sadios, período de 24 horas. Vasos pequenos distribuídos na região da derme. (D) Grupo tratado de animais sadios, período de 15 dias. Barra para todas as fotomicrografias $=50 \mu \mathrm{m}$. (E) Número de vasos marcados pelo fvW por área média de $33.344,20 \mu \mathrm{m}^{2}$. Os dados estão representados por média e desvio padrão. $\left.{ }^{*}\right) P<0,05 \mathrm{em}$ relação ao grupo controle, teste não pareado $t$-Student $(\mathrm{n}=5)$.

\subsubsection{Avaliação da expressão imuno-histoquímica e expressão gênica por RT-PCR em alvos moleculares envolvidos no desenvolvimento do CEC}

As avaliações na expressão das proteínas H-ras e p53 foram obtidas de forma qualitativa pela técnica de imuno-histoquímica e de forma qualitativa pela avaliação da expressão gênica de H-ras e p53 pela técnica de RT-PCR em tempo real. 


\subsubsection{H-ras}

Na técnica de imuno-histoquímica, o perfil da expressão de H-ras foi citoplasmático em todos os grupos experimentais com distribuição difusa e marcação predominante no estrato espinhoso da epiderme, mas também em algumas células no estrato granuloso e córneo (Figura 22). 

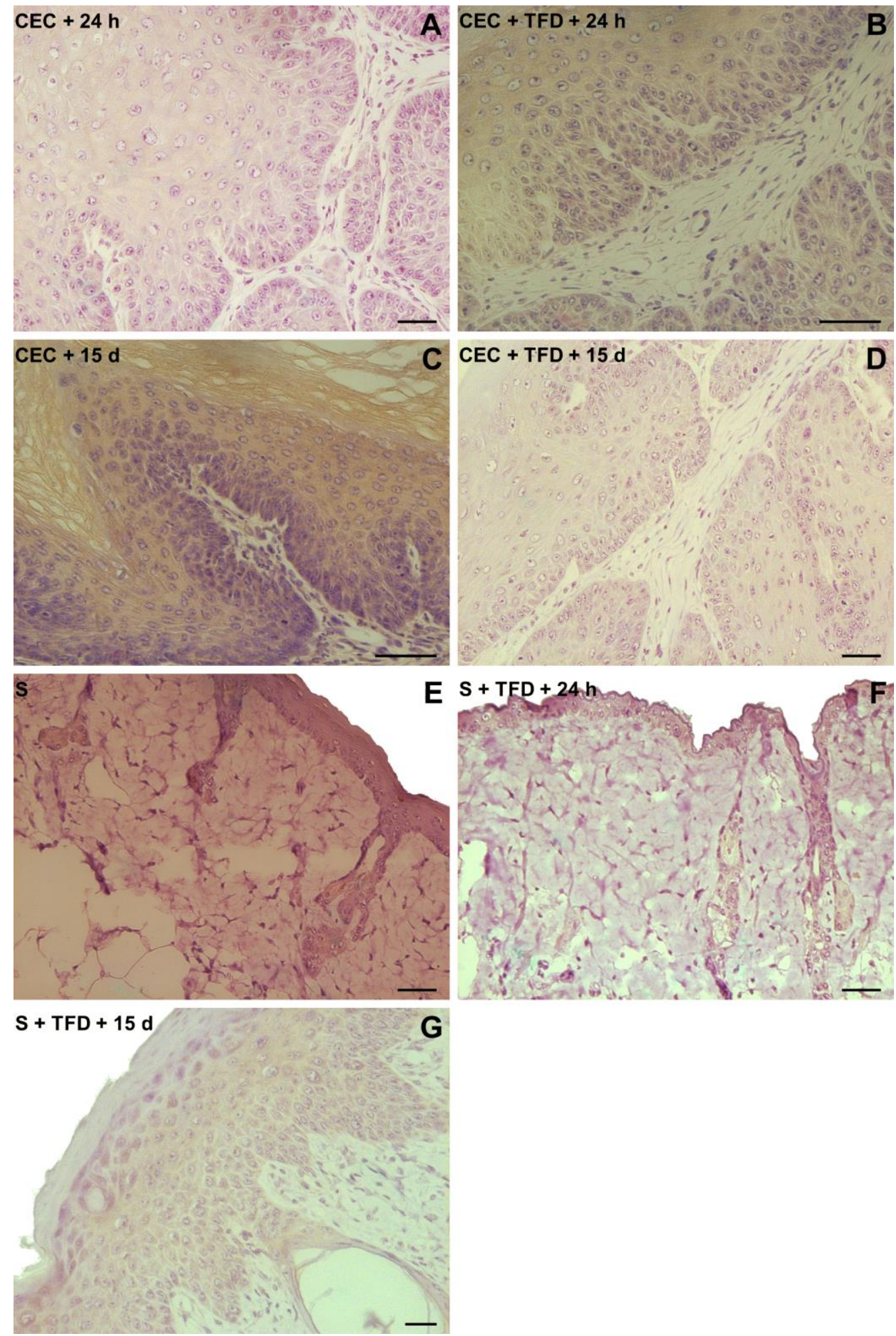

Figura 22 - Fotomicrografias representativas da marcação imuno-histoquímica de H-ras. Notar padrão citoplasmático da marcação. (A e C) Grupos controles de animais induzidos ao CEC, período de 24 horas e 15 dias, respectivamente. (B e D) Grupos tratados de animais induzidos ao CEC, período de 24 horas e 15 dias, respectivamente. (E) Grupo controle de animais sadios. (F) Grupo tratado de animais sadios, período de 24 horas. (G) Grupo tratado de animais sadios, período de 15 dias. Barra $(\mathbf{A}, \mathbf{D}, \mathbf{E}, \mathbf{F}$ e G) $=20 \mu \mathrm{m}$ e $(\mathbf{B}$ e C $)=50$ $\mu \mathrm{m}$. 
A marcação desta proteína foi fraca na maioria dos grupos tanto nos controles como nos tratados (Tabela 5).

Tabela 5 - Escores da intensidade da marcação imuno-histoquímica de H-ras nas amostras controles e tratadas do carcinoma espinocelular cutâneo (CEC) e peles sadias (S) em diferentes estratos da epiderme. Valores expressos como mediana (valor mínimo e máximo, respectivamente)

\begin{tabular}{lcccc}
\hline & Estrato espinhoso & Estrato granuloso & Estrato córneo & n \\
\hline CEC+24 h & $1(1-1)$ & $1(1-1)$ & $0(0-1)$ & 6 \\
CEC+TFD+24 h & $1(0-2)$ & $1(0-1)$ & $0(0-1)$ & 7 \\
CEC+15 d & $0(0-2)$ & $0(0-0)$ & $0(0-2)$ & 6 \\
CEC+TFD+15 d & $0,5(0-1)$ & $0,5(0-1)$ & $0(0-1)$ & 6 \\
S & $1(0-2)$ & $1(0-1)$ & $0(0-0)$ & 5 \\
S+TFD+24 h & $1(0-2)$ & $0(0-0)$ & $0(0-0)$ & 6 \\
S+TFD+15 d & $0(0-1)$ & $1(0-1)$ & $0(0-0)$ & 4 \\
N total & & & & 44 \\
\hline
\end{tabular}

Nota: Intensidade: (0) negativa, (1) fraca, (2) moderada, (3) forte.

No total de células marcadas incluindo todos os grupos experimentais, foi notado que a maioria das células positivas mostrou uma distribuição baixa, em torno de $0-5 \%$ de positividade, ou alta, acima de $75 \%$ de células marcadas. A análise semiquantitativa realizada por escores do número de células positivas ao H-ras está apresentada na Tabela 6.

Tabela 6 - Escores da distribuição da marcação imuno-histoquímica de H-ras em amostras controles e tratadas do carcinoma espinocelular cutâneo (CEC) e peles sadias (S)

\begin{tabular}{lcccccc}
\hline Escores & - & + & ++ & +++ & ++++ & n \\
\hline CEC+24 h & 2 & 0 & 0 & 4 & 0 & 6 \\
CEC+TFD+24 h & 3 & 2 & 0 & 1 & 2 & 8 \\
CEC+15 d & 2 & 2 & 1 & 0 & 1 & 6 \\
CEC+TFD+15 d & 1 & 1 & 0 & 2 & 2 & 6 \\
S & 4 & 1 & 0 & 0 & 0 & 5 \\
S+TFD+24 h & 1 & 0 & 0 & 2 & 3 & 6 \\
S+TFD+15 d & 2 & 1 & 0 & 0 & 4 & 7 \\
N total & 15 & 7 & 1 & 9 & 12 & 44 \\
\hline
\end{tabular}

Nota: (-) negativo $0-5 \%$ de células marcadas, (+) 5-25\% de células positivas, (++) 25-50\% de células positivas, $(+++) 50-75 \%$ de células positivas e $(++++)$ mais de $75 \%$ de células positivas.

O gene H-ras está envolvido na carcinogênese do CEC; a expressão gênica de H-ras dos grupos controles dos animais induzidos ao CEC, nos dois períodos avaliados, foram comparados com o grupo controle dos animais sadios e não houve diferença significativa entre os grupos $(P>0,05)$.

Na comparação entre grupos controles e tratados, foi visto que o grupo CEC tratado no período de 24 horas $(\mathrm{CEC}+\mathrm{TFD}+24 \mathrm{~h}=0,04 \pm 0,01)$ apresentou diminuição significativa $(P=$ $0,0013)$ em relação ao controle $(\mathrm{CEC}+24 \mathrm{~h}=1,00 \pm 0,44)$. No período de 15 dias, o grupo 
tratado $(\mathrm{CEC}+\mathrm{TFD}+15 \mathrm{~d}=0,99 \pm 0,59)$ diminuiu a expressão gênica de H-ras em relação ao seu controle $(\mathrm{CEC}+15 \mathrm{~d}=1,00 \pm 0,79)$, entretanto, a redução não foi significativa $(P=0,98)$. Nos animais sadios, 24 horas após a TFD, o grupo tratado ( $\mathrm{S}+\mathrm{TFD}+24 \mathrm{~h}=1,04 \pm 1,19$ ) não apresentou diferença significativa $(P=0,95)$ quando comparado ao seu controle $(\mathrm{S}=1,00 \pm$ 1,29). No grupo sadio tratado $(\mathrm{S}+\mathrm{TFD}+15 \mathrm{~d}=17,57 \pm 6,94)$ ocorreu aumento significativo $(P$ $=0,0008)$ em relação ao controle $(S=1,00 \pm 1,29)$. Os resultados obtidos da avaliação da expressão gênica de H-ras estão demonstrados na Figura 23.

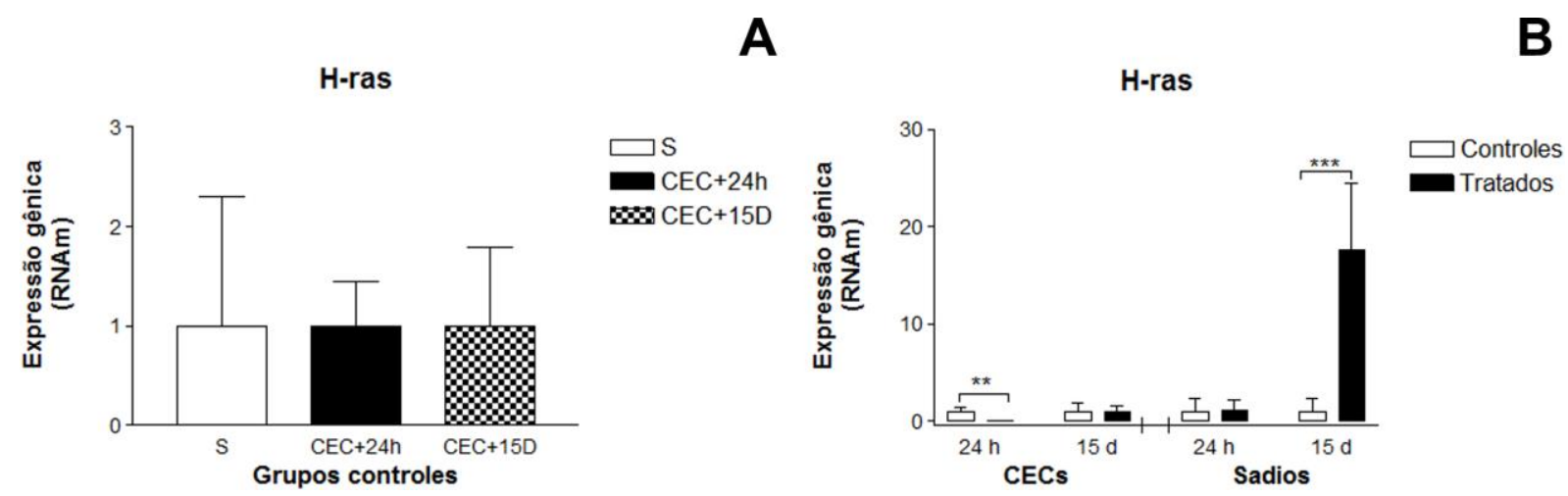

Figura 23 - Expressão do gene H-ras. (A) Expressão gênica de H-ras no grupo controle de animais sadios versus grupos controles de animais induzidos ao CEC nos dois períodos avaliados, 24 horas e 15 dias, respectivamente. Os dados estão representados por média e desvio padrão. Teste ANOVA seguido pelo teste de Tukey-Kramer $(\mathrm{n}=5)$. (B) Expressão gênica de H-ras, grupos controles versus grupos tratados. Os dados estão representados por média e desvio padrão. (**) $P<0,01,(* * *) P<0,001$ em relação ao grupo controle, teste não pareado $t$-Student $(\mathrm{n}=5)$.

\subsubsection{2 p53}

O perfil de expressão imuno-histoquímica da proteína p53 na maioria dos grupos experimentais foi nuclear e citoplasmático. A marcação nuclear ocorreu nos estratos basal e espinhoso da epiderme, e diferenciou no padrão de coloração por DAB que variou da cor amarelada a castanho mais intenso. A marcação citoplasmática, presente no estrato granuloso da epiderme apresentou aspecto difuso (Figura 24). 

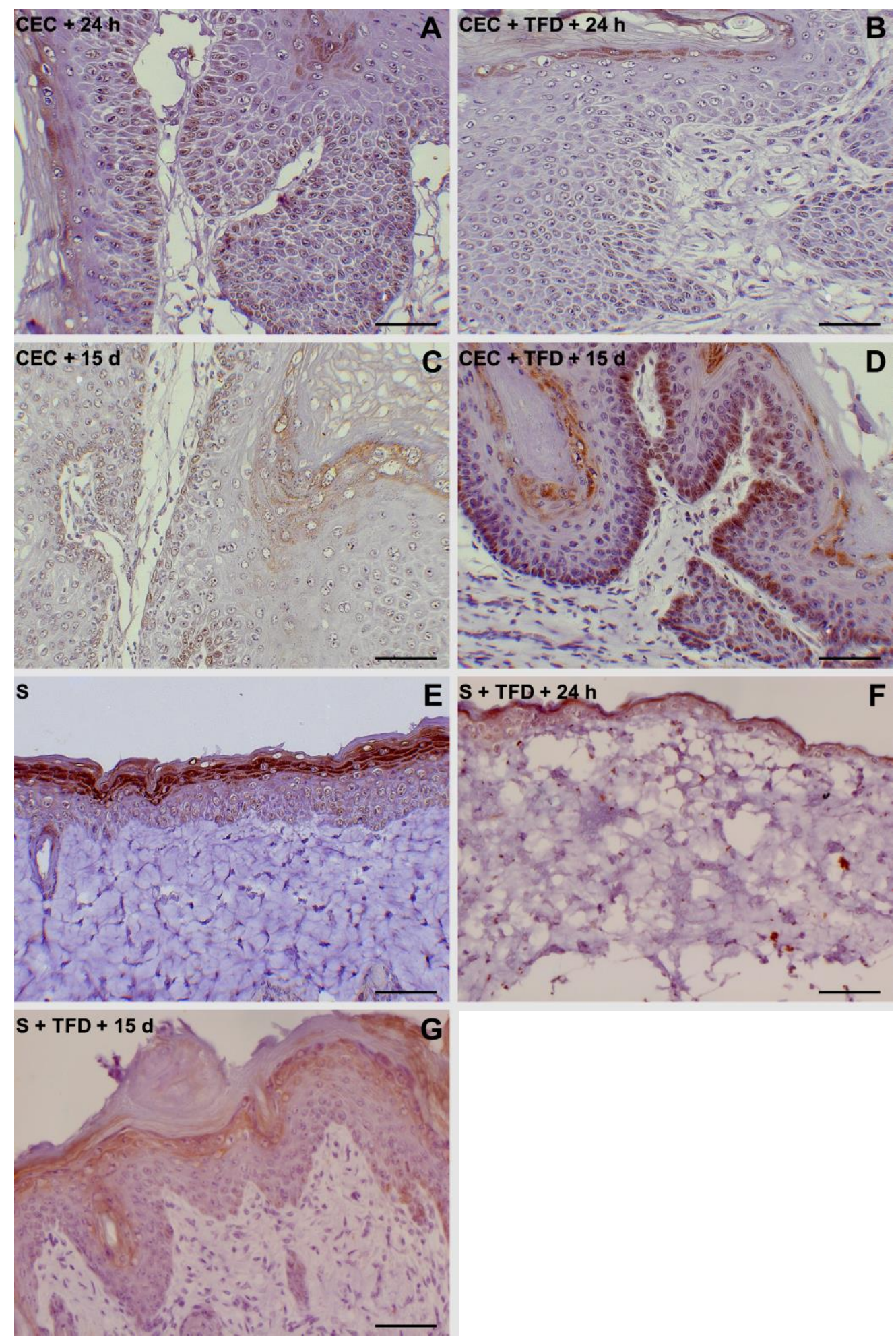

Figura 24 - Fotomicrografias representativas da marcação imuno-histoquímica de p53. Notar padrão citoplasmático e nuclear e diferenças na intensidade de cor. (A e C) Grupos controles de animais induzidos ao CEC, período de 24 horas e 15 dias, respectivamente. (B e D) Grupos tratados de animais induzidos ao CEC, período de 24 horas e 15 dias, respectivamente. (E) Grupo controle de animais sadios. (F) Grupo tratado de animais sadios, período de 24 horas. (G) Grupo tratado de animais sadios, período de 15 dias. Barra $=50 \mu \mathrm{m}$ para todas as fotomicrografias. 
Pela avaliação qualitativa foi observado que a marcação citoplasmática foi intensamente marcada nos grupos tratados com TFD, tanto nos CECs como nos sadios, quando comparados aos seus respectivos controles. A marcação nuclear na maioria dos grupos foi fraca (Tabela 7).

Tabela 7 - Escores da intensidade da marcação imuno-histoquímica de p53 nas amostras controles e tratadas do carcinoma espinocelular cutâneo (CEC) e peles sadias (S) em diferentes estratos da epiderme. Valores expressos como mediana (valor mínimo e máximo, respectivamente)

\begin{tabular}{lccc}
\hline & $\begin{array}{c}\text { Marcação } \\
\text { citoplasmática no } \\
\text { estrato granuloso }\end{array}$ & $\begin{array}{c}\text { Marcação nuclear nos } \\
\text { estratos basal e } \\
\text { espinhoso }\end{array}$ & $\mathbf{n}$ \\
\hline CEC+24 h & $1,5(1-2)$ & $1(1-2)$ & 6 \\
CEC+TFD+24 h & $3(1-3)$ & $3(2-3)$ & 8 \\
CEC+15 d & $1,5(1-2)$ & $2(1-3)$ & 6 \\
CEC+TFD+15 d & $3(1-3)$ & $1(1-3)$ & 5 \\
S & $1(1-3)$ & $1(0-1)$ & 5 \\
S+TFD+24 h & $3(3-3)$ & $1(1-1)$ & 7 \\
S+TFD+15 d & $3(2-3)$ & $1(1-3)$ & 7 \\
N total & & & 44 \\
\hline
\end{tabular}

Nota: Intensidade: (0) negativa, (1) fraca, (2) moderada, (3) forte.

A maioria dos grupos mostrou distribuição acima de $75 \%$ de células positivas à marcação imuno-histoquímica de p53. A análise semiquantitativa realizada por escores do número de células positivas ao p53 está apresentada na Tabela 8.

Tabela 8 - Escores da distribuição da marcação imuno-histoquímica de p53 em amostras controles e tratadas do carcinoma espinocelular cutâneo (CEC) e peles sadias (S)

\begin{tabular}{lllcccc}
\hline Escores & - & + & ++ & +++ & ++++ & n \\
\hline CEC+24 h & 0 & 0 & 0 & 0 & 6 & 6 \\
CEC+TFD+24 h & 0 & 0 & 0 & 0 & 8 & 8 \\
CEC+15 d & 0 & 0 & 0 & 0 & 6 & 6 \\
CEC+TFD+15 d & 0 & 0 & 0 & 0 & 5 & 5 \\
S & 1 & 1 & 0 & 0 & 3 & 5 \\
S+TFD+24 h & 0 & 0 & 1 & 0 & 7 & 7 \\
S+TFD+15 d & 0 & 0 & 0 & 2 & 39 & 44 \\
N total & 1 & 1 & 1 & 2 & 7 & 7 \\
\hline
\end{tabular}

Nota: (-) negativo 0-5\% de células marcadas, $(+)$ 5-25\% de células positivas, $(++)$ 25-50\% de células positivas, (+++) 50-75\% de células positivas e (++++) mais de 75\% de células positivas.

O gene p53 que é um oncogene supressor de tumor, está envolvido na carcinogênese do CEC e no processo de apoptose. A expressão gênica de p53 dos grupos controles dos animais induzidos ao CEC nos dois períodos avaliados, comparados com o grupo controle dos animais sadios, não mostrou diferenças significativas $(P>0,05)$. 
No grupo tratado CEC de 24 horas $(\mathrm{CEC}+\mathrm{TFD}+24 \mathrm{~h}=0,03 \pm 0,01)$ foi observado redução significativa $(P=0,03)$ na expressão gênica de p53 quando comparado ao grupo controle $(\mathrm{CEC}+24 \mathrm{~h}=1,00 \pm 0,82)$. No grupo tratado de 15 dias $(\mathrm{CEC}+\mathrm{TFD}+15 \mathrm{~d}=0,76 \pm$ $1,24)$ houve diminuição na expressão de p53 comparado ao seu controle $(\mathrm{CEC}+15 \mathrm{~d}=1,00 \pm$ $0,67)$, portanto, não foi significativa $(P=0,71)$. Nos grupos sadios tratados ocorreu redução significativa da expressão do gene p53, 24 horas $(\mathrm{S}+\mathrm{TFD}+24 \mathrm{~h}=0,04 \pm 0,06 ; P=0,085)$ e 15 dias $(\mathrm{S}+\mathrm{TFD}+15 \mathrm{~d}=0,005 \pm 0,004 ; P=0,013)$ quando comparados ao controle $(\mathrm{S}=1,00 \pm$ 0,69). Os resultados obtidos estão mostrados na Figura 25.

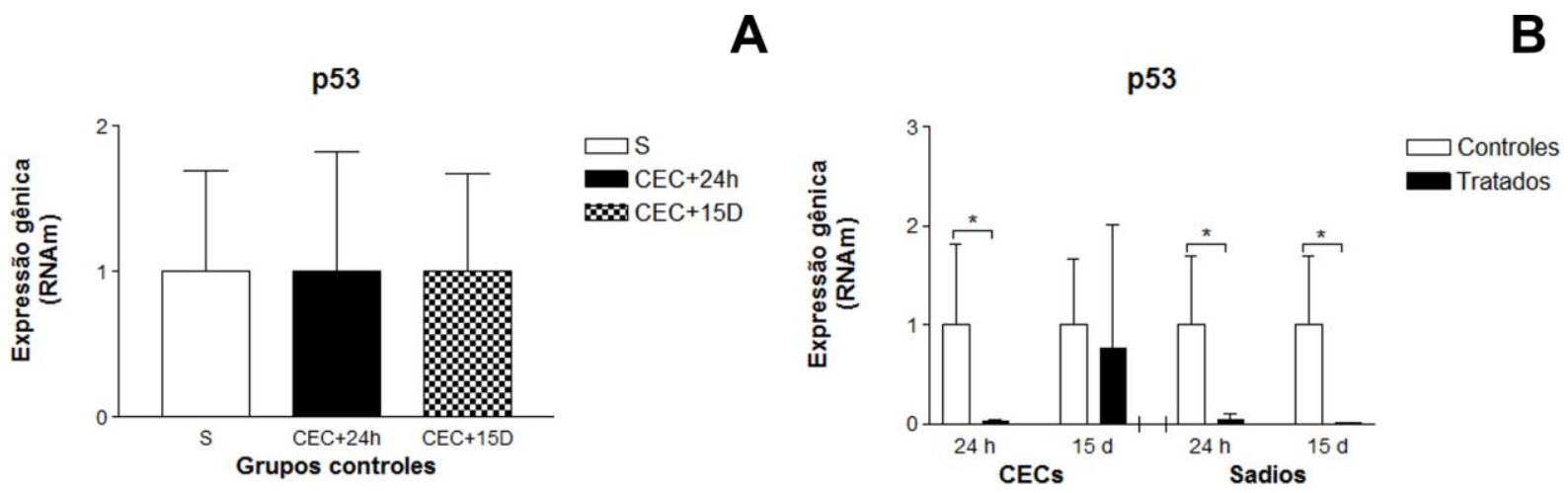

Figura 25 - Expressão do gene p53. (A) Expressão gênica de p53 no grupo controle de animais sadios versus grupos controles de animais induzidos ao CEC nos dois períodos avaliados, 24 horas e 15 dias, respectivamente. Os dados estão representados por média e desvio padrão. Teste ANOVA seguido pelo teste de Tukey-Kramer (n = 5). (B) Expressão gênica de p53, grupos controles versus grupos tratados. Os dados estão representados por média e desvio padrão. (*) $P<0,05$ em relação ao grupo controle, teste não pareado $t$-Student $(\mathrm{n}=5)$.

\subsubsection{Avaliação da expressão imuno-histoquímica e expressão gênica por RT-PCR em alvos moleculares envolvidos na regulação da apoptose}

As avaliações na expressão das proteínas Bak e Bcl-xL foram obtidas de forma qualitativa pela técnica de imuno-histoquímica e de forma qualitativa pela avaliação da expressão gênica de Bak e Bcl-xL pela técnica de RT-PCR em tempo real.

\subsubsection{Bak}

O padrão de marcação da proteína Bak, uma proteína pró-apoptótica que faz parte da família da Bcl-2, foi citoplasmático no estrato granuloso e córneo da epiderme. O estrato córneo que compõe a superfície da pele, como o presente nas pérolas córneas dos CECs, foi marcado. Alguns núcleos de células do sistema imune estavam marcados entre os queratinócitos na epiderme e mais predominantemente, na região dérmica (Figura 26). 

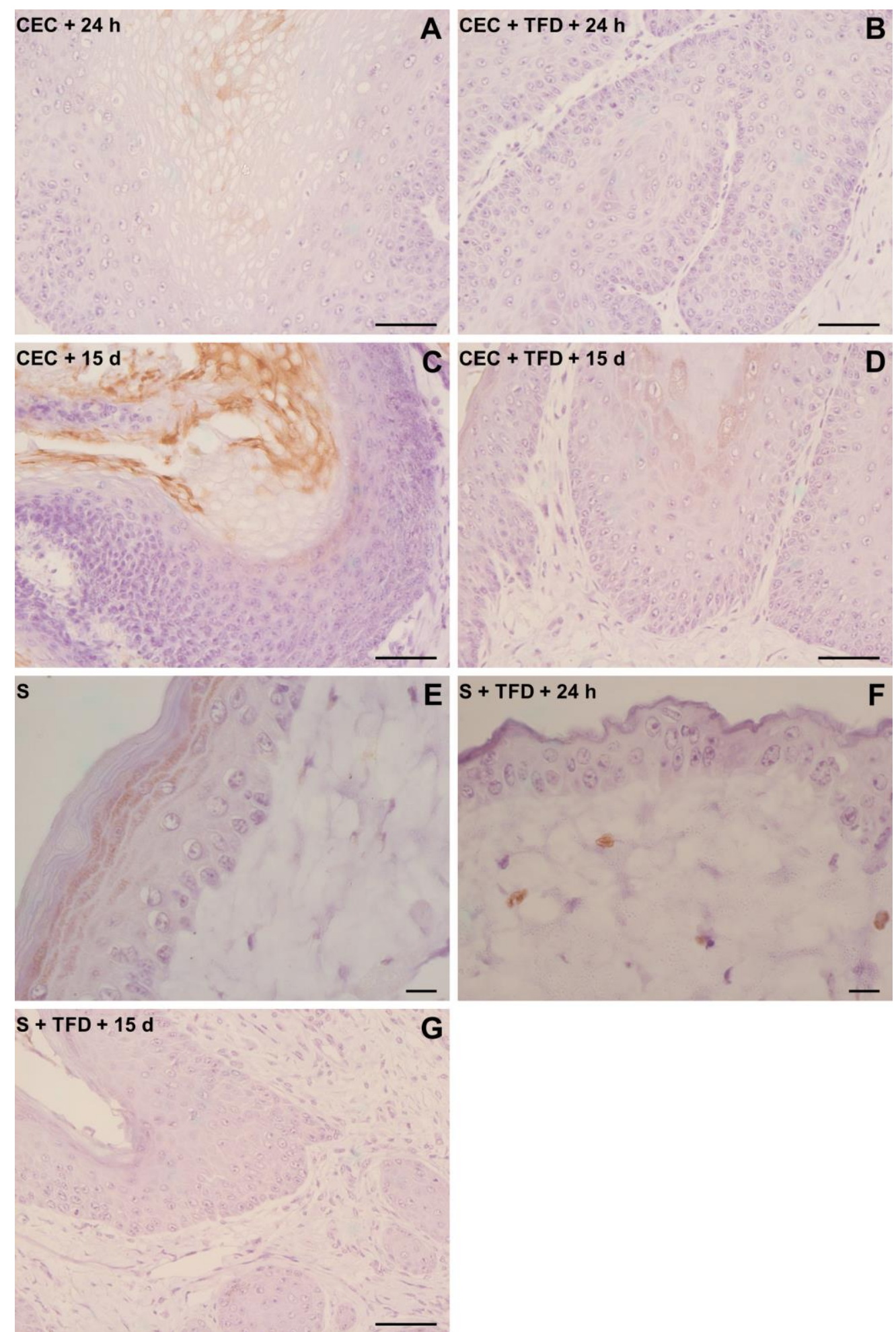

Figura 26- Fotomicrografias representativas da marcação imuno-histoquímica de Bak. Perfil citoplasmático na marcação de Bak. (A e C) Grupos controles de animais induzidos ao CEC, período de 24 horas e 15 dias, respectivamente. (B e D) Grupos tratados de animais induzidos ao CEC, período de 24 horas e 15 dias, respectivamente. (E) Grupo controle de animais sadios. (F) Grupo tratado de animais sadios, período de 24 horas. (G) Grupo tratado de animais sadios, período de 15 dias. Barra (A-D e G) $=50 \mu \mathrm{m}$ e $(\mathbf{E}-\mathbf{F})=10 \mu \mathrm{m}$. 
Na maioria dos grupos, tanto controles como os tratados, a intensidade da marcação de Bak foi negativa, quando presente, a marcação foi predominante nos estratos granuloso e córneo e variou na intensidade de marcação de moderado a forte (Tabela 9).

Tabela 9 - Escores da intensidade da marcação imuno-histoquímica de Bak nas amostras controles e tratadas do carcinoma espinocelular cutâneo (CEC) e peles sadias (S) em diferentes estratos da epiderme e na derme. Valores expressos como mediana (valor mínimo e máximo, respectivamente)

\begin{tabular}{lcccc}
\hline & $\begin{array}{c}\text { Marcação } \\
\text { citoplasmática no } \\
\text { estrato granuloso }\end{array}$ & $\begin{array}{c}\text { Marcação } \\
\text { citoplasmática no } \\
\text { estrato córneo }\end{array}$ & $\begin{array}{c}\text { Marcação nuclear } \\
\text { na derme }\end{array}$ & $\mathbf{n}$ \\
\hline CEC+24 h & $0(0-0)$ & $0(0-2)$ & $0(0-3)$ & 6 \\
CEC+TFD+24 h & $2(0-3)$ & $0(0-3)$ & $1(0-1)$ & 8 \\
CEC+15 d & $0(0-3)$ & $3(2-3)$ & $1(1-3)$ & 5 \\
CEC+TFD+15 d & $0(0-3)$ & $0(0-3)$ & $0(0-1)$ & 7 \\
S & $0(0-3)$ & $0(0-0)$ & $2(2-2)$ & 7 \\
S+TFD+24 h & $0(0-0)$ & $0(0-0)$ & $1(1-3)$ & 7 \\
S+TFD+15 d & $0(0-2)$ & $0(0-0)$ & $0(0-1)$ & 45 \\
N total & & & & 5 \\
\hline
\end{tabular}

Nota: Intensidade: (0) negativa, (1) fraca, (2) moderada, (3) forte.

A maioria dos grupos mostrou distribuição baixa de $0-5 \%$ de células positivas à marcação imuno-histoquímica de Bak. A análise semiquantitativa foi realizada por escores do número de células positivas à Bak e está apresentado na Tabela 10.

Tabela 10 - Escores da distribuição da marcação imuno-histoquímica de Bak em amostras controles e tratadas do carcinoma espinocelular cutâneo (CEC) e peles sadias (S)

\begin{tabular}{lcccccc}
\hline Escores & - & + & ++ & +++ & ++++ & n \\
\hline CEC+24 h & 5 & 0 & 1 & 0 & 0 & 6 \\
CEC+TFD+24 h & 8 & 0 & 0 & 0 & 0 & 8 \\
CEC+15 d & 3 & 0 & 2 & 0 & 0 & 5 \\
CEC+TFD+15 d & 6 & 0 & 0 & 0 & 1 & 7 \\
S & 1 & 0 & 1 & 0 & 3 & 5 \\
S+TFD+24 h & 1 & 2 & 0 & 0 & 3 & 7 \\
S+TFD+15 d & 6 & 0 & 0 & 1 & 8 & 45 \\
N total & 30 & 2 & 4 & 1 & & 7 \\
\hline
\end{tabular}

Nota: (-) negativo 0-5\% de células marcadas, (+) 5-25\% de células positivas, (++) 25-50\% de células positivas, $(+++) 50-75 \%$ de células positivas e $(++++)$ mais de $75 \%$ de células positivas.

A expressão gênica de Bak dos grupos controles dos animais induzidos ao CEC nos dois períodos avaliados foi comparada com o grupo controle dos animais sadios, não foi observada diferença significativa $(P>0,05)$.

$\mathrm{Na}$ avaliação da expressão gênica de Bak foi verificada redução, porém, não significativa $(P=0,14)$ para o grupo CEC tratado no período de 24 horas $(\mathrm{CEC}+\mathrm{TFD}+24 \mathrm{~h}=$ $0,014 \pm 0,06)$ em relação ao seu controle $(\mathrm{CEC}+24 \mathrm{~h}=1,00 \pm 1,16)$. No grupo tratado de 15 
dias $(\mathrm{CEC}+\mathrm{TFD}+15 \mathrm{~d}=1,59 \pm 1,24)$ a expressão de Bak aumentou em relação ao controle $(\mathrm{CEC}+15 \mathrm{~d}=1,00 \pm 2,23)$, portanto, essa redução não apresentou diferença significativa $(P=$ 0,51). Nos grupos sadios tratados $(\mathrm{S}+\mathrm{TFD}+24 \mathrm{~h}=1,14 \pm 1,56)$ e $(\mathrm{S}+\mathrm{TFD}+15 \mathrm{~d}=20,53 \pm$ 13,69) ocorreu aumento na expressão de Bak comparando ao controle $S(1,00 \pm 1,24)$, entretanto, apenas o aumento no grupo tratado de 15 dias foi significativa $(P=0,89 ; P=$ 0,026, respectivamente). Os resultados estão demonstrados na Figura 27.
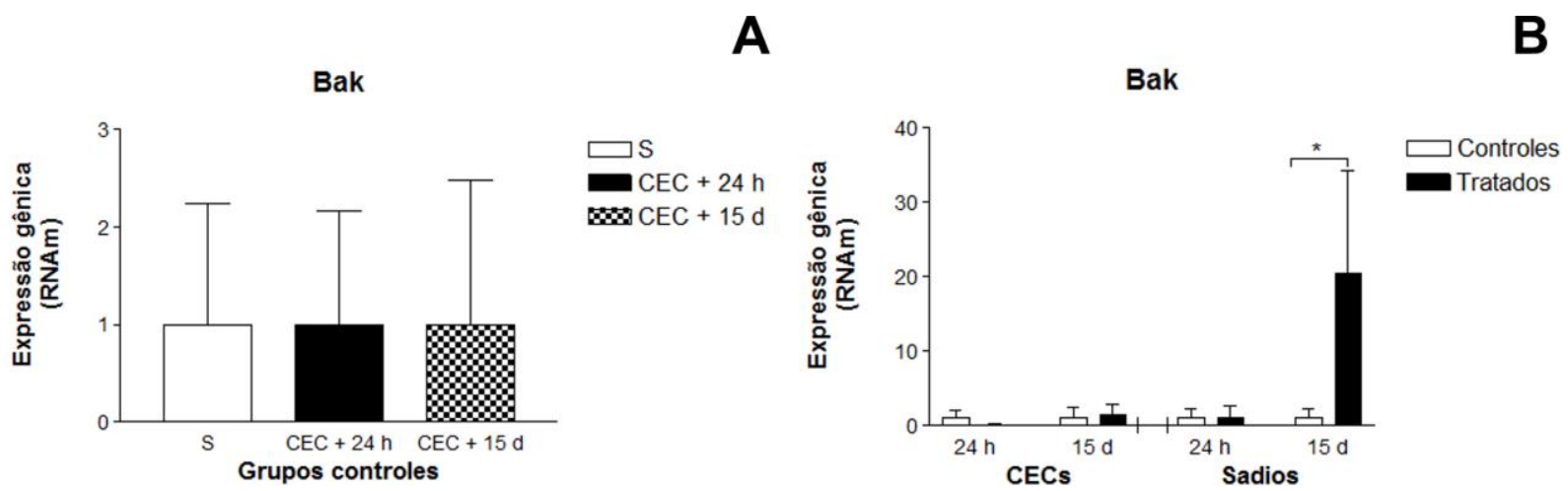

Figura 27 - Expressão do gene Bak. (A) Expressão gênica de Bak do grupo controle de animais sadios versus grupos controles de animais induzidos ao CEC nos dois períodos avaliados, 24 horas e 15 dias, respectivamente. Os dados estão representados por média e desvio padrão. Teste ANOVA seguido pelo teste de Tukey-Kramer (n = 5). (B) Expressão gênica de Bak, grupos controles versus grupos tratados. Os dados estão representados por média e desvio padrão. $\left.{ }^{*}\right) P<0,05$ em relação ao grupo controle, teste não pareado $t$-Student $(\mathrm{n}=5)$.

\subsubsection{Bcl-xL}

A detecção de Bcl-xL, proteína antiapoptótica, membro da família Bcl-2, mostrou que a localização dessa proteína na epiderme é citoplasmática, com predomínio nos estratos espinhoso, granuloso e córneo na maioria dos grupos. Entre os queratinócitos, no estrato espinhoso, alguns núcleos de células do sistema imune foram marcados. Na derme também foram observados vários núcleos intensamente marcados, na maioria dos grupos, em especial nas áreas de infiltrado de células inflamatórias (Figura 28). 

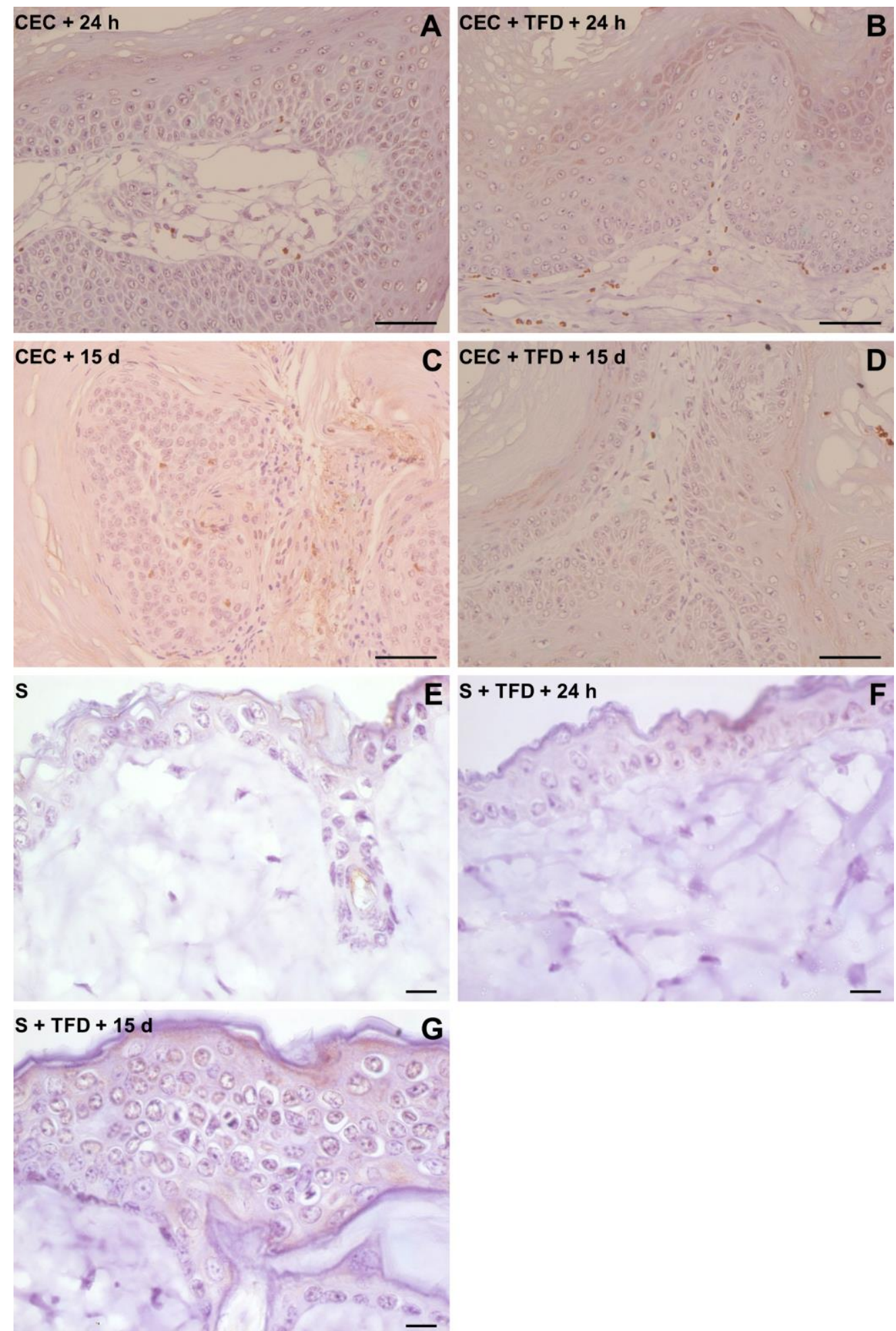

Figura 28- Fotomicrografias representativas da marcação imuno-histoquímica de Bcl-xL. Notar perfil citoplasmático da Bcl-xL. (A e C) Grupos controles de animais induzidos ao CEC, período de 24 horas e 15 dias, respectivamente. (B e D) Grupos tratados de animais induzidos ao CEC, período de 24 horas e 15 dias, respectivamente. (E) Grupo controle de animais sadios. (F) Grupo tratado de animais sadios, período de 24 horas. (G) Grupo tratado de animais sadios, período de 15 dias. Barra (A-D) $=50 \mu \mathrm{m}$ e (E-G) $=10 \mu \mathrm{m}$. 
Tanto os grupos controles como os tratados, a intensidade da marcação desta proteína foi fraca nos estratos da epiderme e forte nos núcleos de células na região da derme (Tabela $11)$.

Tabela 11 - Escores da intensidade da marcação imuno-histoquímica de Bcl-xL nas amostras controles e tratadas do carcinoma espinocelular cutâneo (CEC) e peles sadias (S) em diferentes estratos da epiderme e na derme. Valores expressos como mediana (valor mínimo e máximo, respectivamente)

\begin{tabular}{lccccc}
\hline & $\begin{array}{c}\text { Marcação } \\
\text { citoplasmática } \\
\text { no estrato } \\
\text { espinhoso }\end{array}$ & $\begin{array}{c}\text { Marcação } \\
\text { citoplasmática } \\
\text { no estrato } \\
\text { granuloso }\end{array}$ & $\begin{array}{c}\text { Marcação } \\
\text { citoplasmática } \\
\text { no estrato } \\
\text { córneo }\end{array}$ & $\begin{array}{c}\text { Marcação } \\
\text { nuclear na } \\
\text { derme }\end{array}$ & $\mathbf{n}$ \\
\hline CEC+24 h & $1(1-1)$ & $1(1-3)$ & $1(1-1)$ & $3(2-3)$ & 6 \\
CEC+TFD+24 h & $1(0-1)$ & $1(1-2)$ & $0(0-1)$ & $3(3-3)$ & 6 \\
CEC+15 d & $0(0-1)$ & $1(1-1)$ & $0(0-1)$ & $3(3-3)$ & 5 \\
CEC+TFD+15 d & $0(0-1)$ & $1(0-2)$ & $0(0-0)$ & $3(3-3)$ & 5 \\
S & $2(1-2)$ & $1(0-2)$ & $0(0-0)$ & $0(0-0)$ & 5 \\
S+TFD+24 h & $1(1-3)$ & $1(1-3)$ & $0(0-0)$ & $3(3-3)$ & 6 \\
S+TFD+15 d & $1(1-2)$ & $1,5(1-3)$ & $0(0-0)$ & $2(0-3)$ & 6 \\
N total & & & & & 39 \\
\hline
\end{tabular}

Nota: Intensidade: (0) negativa, (1) fraca, (2) moderada, (3) forte.

Quanto à distribuição de células marcadas por Bcl-xL, a maioria dos grupos, tanto controles como tratados apresentou distribuição entre 0-5\% de células marcadas. Os escores de distribuição desse antígeno variaram muito entre os grupos. A análise semiquantitativa realizada por escores do número de células positivas à Bcl-xL está apresentada na Tabela 12.

Tabela 12 - Escores da distribuição da marcação imuno-histoquímica de Bcl-xL em amostras controles e tratadas do carcinoma espinocelular cutâneo (CEC) e peles sadias (S)

\begin{tabular}{lcccccc}
\hline Escores & - & + & ++ & +++ & ++++ & n \\
\hline CEC+24 h & 3 & 0 & 3 & 0 & 0 & 6 \\
CEC+TFD+24 h & 2 & 1 & 0 & 1 & 2 & 6 \\
CEC+15 d & 0 & 1 & 1 & 2 & 1 & 5 \\
CEC+TFD+15 d & 0 & 0 & 2 & 1 & 2 & 5 \\
S & 4 & 1 & 0 & 0 & 0 & 5 \\
S+TFD+24 h & 2 & 3 & 0 & 0 & 1 & 6 \\
S+TFD+15 d & 2 & 1 & 2 & 0 & 1 & 6 \\
N total & 13 & 7 & 8 & 4 & 7 & 39 \\
\hline
\end{tabular}

Nota: (-) negativo 0-5\% de células marcadas, (+) 5-25\% de células positivas, (++) 25-50\% de células positivas, (+++) 50-75\% de células positivas e (++++) mais de 75\% de células positivas.

O gene Bcl-xL é um oncogene que está envolvido na carcinogênese do CEC e codifica uma proteína antiapoptótica. A expressão gênica de Bcl-xL nos grupos controles dos animais induzidos ao CEC, nos dois períodos avaliados, foi comparada com o grupo controle dos animais sadios, não foi indicada diferença significativa $(P>0,05)$. 
A avaliação da expressão gênica de Bcl-xL indicou redução significativa $(P=0,023)$ no grupo CEC tratado no período de 24 horas $(\mathrm{CEC}+\mathrm{TFD}+24 \mathrm{~h}=0,079 \pm 0,03)$, em relação ao controle $(\mathrm{CEC}+24 \mathrm{~h}=1,00 \pm 0,73)$. O grupo CEC tratado de 15 dias $(\mathrm{CEC}+\mathrm{TFD}+15 \mathrm{~d}=$ $2,57 \pm 3,53)$ apresentou aumento na expressão de Bcl-xL em relação ao controle (CEC+15 d = $1,00 \pm 1,20)$, porém não significativo $(P=0,32)$. Os grupos sadios tratados $(\mathrm{S}+\mathrm{TFD}+24 \mathrm{~h}=$ $0,17 \pm 0,23)$ e $(S+T F D+15 d=0,29 \pm 0,43)$ apresentaram redução na expressão deste gene em relação ao controle $(S=1,00 \pm 0,96)$, entretanto, não significativa $(P=0,10 ; P=0,18$, respectivamente). Os dados obtidos estão apresentados na Figura 29.

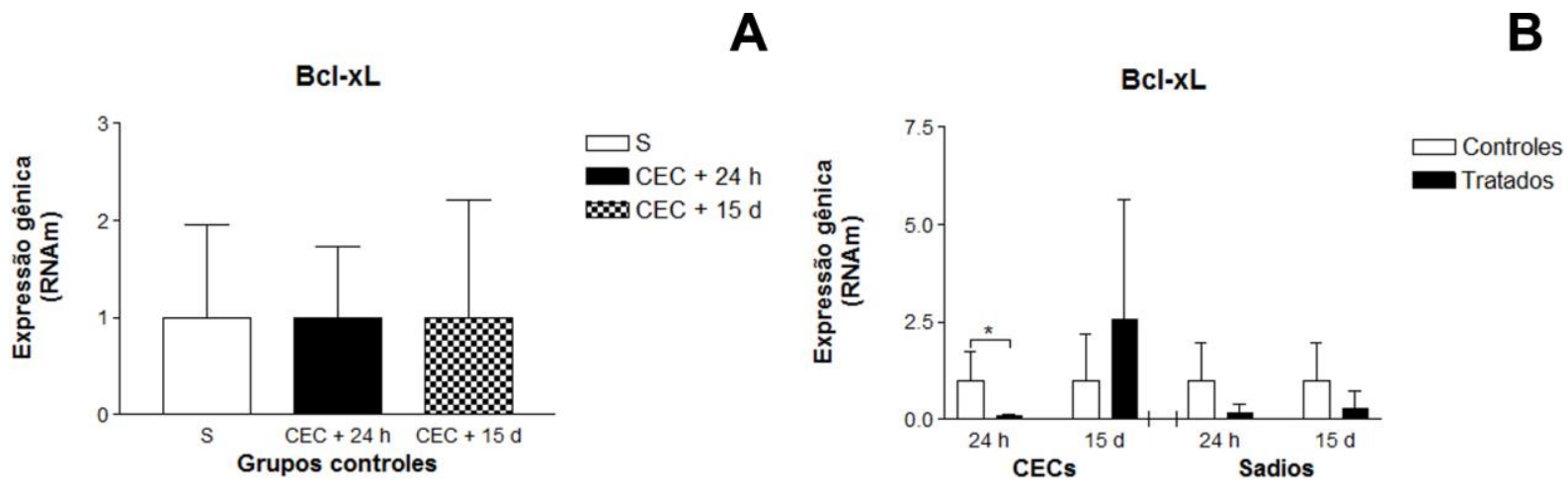

Figura 29 - Expressão do gene Bcl-xL. (A) Expressão gênica de Bcl-xL do grupo controle de animais sadios versus grupos controles de animais induzidos ao CEC nos dois períodos avaliados, 24 horas e 15 dias, respectivamente. Os dados estão representados por média e desvio padrão. Teste ANOVA seguido pelo teste de Tukey-Kramer $(\mathrm{n}=5)$. (B) Expressão gênica de Bcl-xL, grupos controles versus grupos tratados. Os dados estão representados por média e desvio padrão. (*) $P<0,05$ em relação ao grupo controle, teste não pareado $t$-Student $(\mathrm{n}=5)$. 


\section{DISCUSSÃO}

A TFD foi aprovada para o tratamento de queratose actínica, doença de Bowen e CBC superficial, mas há poucos resultados clínicos efetivos no tratamento do CEC (CALZAVARA-PINTON et al., 2008). Neste estudo, os efeitos de uma única sessão da TFD mediada por AM (TFD-AM) no modelo experimental in vivo do CEC foram avaliados em períodos diferentes, 24 horas e 15 dias após tratamento. As respostas da TFD foram analisadas em tecidos tumorais e sadios. Os resultados obtidos mostraram alterações morfológicas e na expressão de proteínas e genes relacionados ao CEC ou apoptose.

No presente trabalho, o modelo experimental de carcinogênese química na indução ao CEC apresentou similaridades com os cânceres desenvolvidos nos humanos, com estágios de iniciação, promoção e progressão (POIRIER, 2012). Todos os animais desenvolveram tumores e a regressão destes tumores foi baixa (3\%), a regressão é um fenômeno comum neste tipo de modelo experimental (DIGIOVANNI, 1992). A indução do CEC pelos agentes químicos não provocou perda de peso dos animais durante o período experimental e o tratamento pela TFD também não influenciou no peso. Somente quatro animais morreram durante o período experimental, destes quatro, apenas um morreu após a TFD, estas foram outras vantagens neste modelo experimental.

Com relação ao aspecto macroscópico, ocorreu diminuição no tamanho em diâmetro dos tumores tratados nos dois períodos avaliados. Estes resultados corroboram com os achados de Wagner et al. (2012) em tumores melanomas B16F10 transplantados em camundongos e tratados pela TFD-AM, com irradiação por RL50 ${ }^{\circledR}$ na dose total de $30 \mathrm{~J} / \mathrm{cm}^{2}$; ocorreu diminuição no volume destes tumores em $99 \%$ dos grupos tratados. Da mesma forma, tumores subcutâneos xenotransplantados em camundongos foram tratados com duas sessões da TFD-AM, comprimento de onda a $662 \mathrm{~nm}$, na dose total de $100 \mathrm{~J} / \mathrm{cm}^{2}$, nesse trabalho foi relatado destruição completa dos tumores em 79\% dos animais tratados (ORTH et al., 2000). Apesar da dosagem mais baixa usada no presente trabalho, comparada aos estudos citados acima, uma única aplicação da TFD-AM na dose total de $24 \mathrm{~J} / \mathrm{cm}^{2}$ foi eficaz na redução tumoral. Na avaliação macroscópica, a maioria dos tumores tratados apresentou necrose ou ulceração na superfície tumoral, isto, explica a redução no tamanho dos tumores desta pesquisa.

No presente trabalho, cada tumor representou uma unidade amostral para as avaliações microscópicas, pois no mesmo animal, os tumores apresentaram diferenças no tamanho, morfologia e classificação histopatológica. Dentre os tumores avaliados, mais de $60 \%$ foram 
classificados como CECs, esta porcentagem é satisfatória quando comparada com outros trabalhos utilizando DMBA/TPA em linhagens de camundongos mais susceptíveis, como a linhagem SENCAR (SLAGA, 1986). A classificação histopatológica permitiu a seleção das lesões malignas para verificar os efeitos da TFD nos CECs, como proposto neste estudo.

A avaliação histopatológica após TFD-AM nos tecidos tumorais indicou poucas alterações morfológicas quando estas lesões foram comparadas com os controles. Uma única sessão da TFD-AM não foi suficiente para a destruição total da área neoplásica. A maioria dos CECs nesta pesquisa apresentou alto grau de queratinização, a hipótese é que isso pode ter dificultado a penetração da luz e contribuído com a preservação da área neoplásica. Este dado é de extrema importância para pesquisas futuras, para ajustes no protocolo tanto na dose total como no número de sessões da TFD no tecido tumoral. A dificuldade dos pacientes com CEC responderem ao tratamento pela TFD já foi relatada na literatura (CALZAVARAPINTON et al., 2008).

No aspecto morfológico, os efeitos da TFD foram mais evidenciados nos tecidos sadios do que nos tecidos tumorais. A destruição estrutural do tecido sadio na área dérmica foi muito acentuada 24 horas após o tratamento. No período de 15 dias ocorreu aumento na espessura da epiderme e alterações na derme que se referiram à presença de fibroblastos reativos, infiltrado inflamatório e neovascularização, indicando que o tecido está progredindo para uma fase de remodelamento neste período. Estes dados corroboram com os achados de Garcia et al. (2010) no tratamento pela TFD mediada por azul de toluidina na cicatrização de queimaduras de terceiro grau provocadas experimentalmente em ratos, na dose total de 4,5 $\mathrm{J} / \mathrm{cm}^{2}$; no período de 14 dias ocorreu reepitelização com espessura irregular da epiderme, na derme presença de infiltrado inflamatório constituído de células relacionadas com a inflamação aguda e crônica, alguns vasos neoformados e aumento de fibras colágenas; o tratamento melhorou a cicatrização da pele queimada dos ratos. Do mesmo modo, as alterações vistas em nossa pesquisa, indicaram que o tecido sadio 15 dias após TFD, pode estar se reestruturando tanto na área epitelial como na região dérmica.

O colágeno diminuiu nos tecidos sadios tratados nos dois períodos avaliados, essa redução confirma as alterações morfológicas citadas anteriormente no tecido sadio, com destruição dos componentes da derme. Na pele de camundongos submetidos ao tratamento pela TFD mediada por aminolevulinato de metila (TFD-MAL), a cinética da expressão gênica do colágeno tipo I mostrou aumento após 21 dias do tratamento (CHOI et al., 2010). Observações em longo prazo da quantificação do colágeno e análise histopatológica poderão esclarecer se ocorrerá nova formação de colágeno para remodelamento desta área no tecido 
sadio, já que as observações no presente trabalho indicaram desarranjo de fibras colágenas no período de 24 horas e no período de 15 dias, fibroblastos reativos estavam presentes após a TFD.

Outro aspecto importante para tratamentos contra o câncer é a análise das proteínas relacionadas ao estado proliferativo das células. O PCNA é um antígeno que apresenta maior expressão na fase $\mathrm{S}$ do ciclo celular durante a replicação do DNA e está envolvido nos mecanismos de reparo do DNA (STRZALKA; ZIEMIENOWICZ, 2011). Embora haja outros marcadores de proliferação como o KI-67, presente em todas as fases do ciclo celular, este tipo de análise correlacionando o PCNA com o estado proliferativo das células é bem aceito no meio científico quando se compara o índice de PCNA entre grupos experimentais, uma vez que esta proteína exerce papel importante na regulação do ciclo celular (MAGA; HUBSCHER, 2003).

O índice de positividade ao PCNA apresentou redução significativa nos grupos tratados de animais induzidos ao CEC e sadios, 15 dias após a TFD. A redução da marcação pelo PCNA concorda com os achados de Wagner et al. (2012) que demonstraram diminuição em 76\% de células marcadas por esse antígeno em melanomas B16F transplantados em camundongos e tratados pela TFD-AM. Barcessat et al. (2013) mostraram resultados contrários, com aumento na expressão de PCNA após 72 horas da TFD-ALA, em lesões orais potencialmente malignas induzidas em ratos, após esse período outras dosagens da TFD foram recomendadas para a remissão total da lesão. As variantes da TFD, como tipos de FS, luz, dosagem e tecido contribuem para resultados diferentes em cada pesquisa (DOUGHERTY; GOMER; HENDERSON, 1998). No presente trabalho, a redução no índice de PCNA no tecido tumoral indica que a TFD-AM resultou em efeito antiproliferativo, importante na redução do tamanho dos tumores e na malignidade. No tecido sadio após 15 dias do tratamento, a diminuição nos índices do PCNA é um bom indicativo de que o aumento na espessura epitelial observado na morfologia tende a diminuir após esse período.

$\mathrm{Na}$ avaliação da apoptose pela reação de TUNEL ocorreu aumento de células positivas nos grupos tratados, portanto, sem diferenças significativas em relação aos controles. $\mathrm{O}$ alto índice de células marcadas por essa técnica tem sido questionado na literatura (CUELLOCARRIÓN; CIOCCA, 1999; STÄHELIN et al., 1998), portanto, para validar esses dados células positivas à marcação imuno-histoquímica pela caspase 3 clivada foram avaliadas. Os grupos tratados de pele sadia apresentaram maior índice de células positivas à caspase $3 \mathrm{em}$ relação aos controles, mostrando que os efeitos da TFD no grupo sadio, de pele fina, foram mais pronunciados que nos grupos induzidos ao CEC. A TFD-AM comumente ativa a 
apoptose pela via intrínseca mitocondrial com liberação do cyt c para o citoplasma e consequente ativação da caspase 3 clivada, como demonstrado em estudos in vitro no tratamento de células HeLa (LU et al., 2008) e em células de melanoma B16F1 (CHEN et al., 2008). Diante do exposto, a baixa quantificação da caspase 3 clivada nos grupos CECs tratados pode estar relacionada à intensa queratinização deste tecido, além disso, o protocolo da TFD-AM utilizado neste trabalho com única sessão pela TFD, na dose total de $24 \mathrm{~J} / \mathrm{cm}^{2}$, pode ter dificultado as respostas imediatas pela via intrínseca da apoptose. Mais estudos são necessários para esclarecer se o aumento na dose total poderá inferir no aumento do índice de marcadores de morte celular por apoptose, ou mais sessões da TFD nesta dosagem serão mais efetivos em causar a morte celular.

Há outros mecanismos que as células podem responder ao dano fotodinâmico, como por exemplo, a ativação do sistema imune. A TFD pode aumentar a ativação de células T CD8 em alguns tipos específicos de neoplasias, as quais requerem o MHC-I para o reconhecimento de antígenos e ativação (BELICHA-VILLANUEVA et al., 2012). No presente trabalho, não foram observadas alterações significativas na marcação de CD8 entre grupos tratados e controles, em geral, a expressão deste antígeno permaneceu baixa após o tratamento. Estes dados corroboram com a pesquisa de Fantini et al. (2008) no tratamento do CBC e doença de Bowen, a marcação de CD8 foi baixa após a TFD-ALA. Por meio da morfologia, os tipos celulares mais evidenciados nos infiltrados inflamatórios do CEC foram os neutrófilos, plasmócitos e linfócitos; contudo, os grupos controles e tratados não mostraram diferenças relevantes. O próprio modelo de indução do CEC, utilizando o carcinógeno TPA favorece a presença de infiltrado inflamatório, como indicado na literatura (ABEL et al., 2009; DIGIOVANNI, 1992), isto dificultou a distinção entre o infiltrado inflamatório especificamente produzido pela TFD. Além disso, não foi possível quantificar esses grupos celulares separadamente, indicando quais os tipos de linfócitos estariam participando destas respostas nos períodos de 24 horas e 15 dias. Provavelmente, o linfócito CD8, célula efetora da resposta imune adaptativa, nos períodos avaliados não estaria ativos para influenciar a morte celular.

Estudos pré-clínicos demonstraram que o tratamento local pela TFD nos tumores pode resultar em efeitos sistêmicos generalizados que incluem indução de neutrofilia sistêmica (CECIC; PARKINS; KORBELIK, 2001), indução de proteínas de fase aguda (GOLLNICK et al., 2003) e liberação sistêmica de citocinas pró-inflamatórias (YOM et al., 2003). Na presente pesquisa, as concentrações plasmáticas de algumas citocinas na modulação da resposta imune após TFD foram avaliadas. 
A citocina TNF- $\alpha$ esta relacionada com dois mecanismos importantes na resposta celular: o efeito pró-inflamatório e a apoptose (BUYTAERT; DEWAELE; AGOSTINIS, 2007; CASTANO; MROZ; HAMBLIN, 2006). A avaliação de TNF- $\alpha$ indicou níveis baixos na maioria dos grupos experimentais. Nossos resultados diferem dos apresentados por Wang et al. (2013) em camundongos induzidos ao CEC por irradiação UVB e tratados pela TFD mediada por ácido 5-aminolevulínico (TFD-ALA), em que ocorreu aumento na marcação imuno-histoquímica, tanto de CD8 como de TNF- $\alpha$, após uma semana do tratamento. Por outro lado, nossos resultados corroboram com os de Byun et al. (2009) que avaliaram a citocina TNF- $\alpha$ por RT-PCR e pelo ensaio de ELISA em cultura de queratinócitos (HaCaT) que receberam tratamento pela TFD-ALA em diferentes dosagens; ambos ensaios demostraram que a concentração desta citocina foi baixa nessa linhagem celular tratada. No trabalho de Takahashi et al. (2008) ocorreu inibição da secreção de TNF- $\alpha$ in vitro 24 horas após tratamento pela TFD mediada por ATX-S10 (Na) nas células HuT102 irradiadas com laser diodo, também ocorreu diminuição na proliferação de linfócitos. O aumento nos níveis de TNF- $\alpha$ está relacionado com macrófagos ativados que secretam esta citocina (CASTANO; MROZ; HAMBLIN, 2006; EVANS et al., 1990). Nosso estudo histopatológico revelou que os macrófagos não estão entre os principais tipos celulares encontrados nos tecidos tumorais tratados, provavelmente isto colaborou com a baixa quantificação desta citocina.

Os queratinócitos na epiderme junto com as células de Langerhans podem secretar TFN- $\alpha$ em tecidos sadios em resposta às injúrias sofridas no tecido, além disso, quando secretado pelos queratinócitos pode inibir o crescimento dessas células (MCKAY; LEIGH, 1991). No grupo sadio tratado 15 dias após TFD ocorreu aumento significativo de TNF- $\alpha$, uma vez que nossa avaliação foi realizada pelos níveis plasmáticos e não no tecido, o aumento desta citocina pode ser explicado por três hipóteses: a primeira pode estar relacionada à resposta pró-inflamatória por causa das injúrias sofridas no tecido após o tratamento; a segunda é que TNF- $\alpha$ pode atuar na inibição do crescimento do tecido, isto corrobora com o fato deste grupo apresentar diminuição na marcação de PCNA que indicam uma possível parada no crescimento deste epitélio; a terceira é que esta citocina participa do processo de morte celular, pela via extrínseca da apoptose, este dado apoia os resultados obtidos pela marcação da caspase 3 neste grupo.

Do ponto de vista qualitativo, a concentração de $1 \mathrm{~L}-1 \beta$ foi maior do que os níveis de TNF- $\alpha$ entre os grupos. Assim como TNF- $\alpha$, o IL-1 $\beta$ é secretado principalmente por macrófagos ativados, porém esta citocina é secretada também por neutrófilos, células $\mathrm{T}$, células epiteliais, entre outras (CONTASSOT; BEER; FRENCH, 2012). Pela avaliação 
morfológica, os grupos induzidos ao CEC controles e tratados, apresentaram muitos neutrófilos no tecido, contudo, a quantificação destas células não foi realizada neste trabalho. De Vree et al. (1997) demonstraram que o aumento de neutrófilos na circulação periférica está relacionado com a elevação nas concentrações séricas de IL-1 $\beta$; isto poderia explicar porque a concentração de IL-1 $\beta$ foi maior que TNF- $\alpha$ em nossa pesquisa.

No grupo CEC tratado 15 dias após a TFD, a concentração de IL-1 $\beta$ aumentou, fator indicativo de que reações inflamatórias ocorreram durante este período. Kawczyk-Krupka et al. (2011) associaram a diminuição de IL-1 $\beta$ como bom prognóstico em inibir a progressão tumoral, visto que processos inflamatórios estimulariam o crescimento e invasão tumoral. Ao contrário, Sun et al. (2003) descreveram que as taxas de curas são diminuídas em tumores com depleção de neutrófilos e IL-1 $\beta$. Diante do exposto, trabalhos futuros poderão elucidar melhor se a elevação nos níveis plasmáticos de IL-1 $\beta$ poderá contribuir na atividade antitumoral ou se estimulará o crescimento tumoral neste tipo de modelo experimental.

A citocina IL-2 apresentou a concentração aumentada nos dois grupos induzidos ao CEC e tratados, 24 horas e 15 dias após TFD. A IL-2 é um fator de crescimento de células T e junto com TNF- $\alpha$ representam as principais citocinas produtoras da resposta Th1, responsáveis pela ativação dos macrófagos. A IL-2 pode estimular a produção de células T reg (CD4+/CD25+) que atuam na ativação de linfócitos T CD8 (BACHMANN; OXENIUS, 2007). Korbelik e Dougherty (1999) relataram que a depleção in vivo das células T CD4 ou bloqueadores do receptor de IL-2, utilizando anti-CD25 reduziu a taxa de cura de tumores EMT6 (sarcoma mamário murino). É possível sugerir que o aumento na concentração da IL-2 nos dois períodos avaliados nos grupos de CECs tratados está relacionado com bom prognóstico no tratamento destes tumores, porque esta citocina é secretada por linfócitos $\mathrm{T}$ CD4, molécula ativadora do linfócito T CD8, efetor da resposta imune adaptativa, indicando que possivelmente em algum momento poderia ocorrer ativação efetiva do sistema imune.

Alguns estudos têm apontado que a TFD pode estimular a angiogênese $\mathrm{e}$ consequentemente a progressão tumoral (BHUVANESWARI et al., 2008). Nosso estudo indicou uma tendência no aumento no número de vasos no grupo induzido ao CEC 24 horas após tratamento, portanto sem resultado estatisticamente significativo. Alterações na morfologia dos vasos que indicassem injúria não foram notadas após o tratamento em nenhum dos grupos experimentais. O número de vasos marcados pelo fvW aumentou no grupo sadio tratado 15 dias após a TFD, podemos relacionar este aumento com as alterações morfológicas vistas neste grupo que sugerem que neste período esteja ocorrendo remodelação tecidual. Este resultado precisará ser mais bem elucidado com marcados angiogênicos específicos, como 
VEGF ou CD34, na observação de forma cinética se a TFD-AM pode contribuir com a cicatrização e remodelação deste tecido.

A maioria dos grupos apresentou marcação imuno-histoquímica fraca da proteína $\mathrm{H}$ ras. Quando este gene está mutado favorece a carcinogênese da pele (DIGIOVANNI, 1992). O grupo CEC tratado, após 24 horas da TFD apresentou redução na expressão do gene H-ras, o que confere alteração importante condizente com bom prognóstico do tratamento aplicado. O grupo sadio tratado aumentou a expressão deste gene após 15 dias da TFD. A proteína Hras está correlacionada com mecanismos de proliferação e expressão de enzimas que degradam o colágeno como demonstrado no modelo in vitro de pele, na qual a expressão de H-ras afetou a integridade tecidual, com invasão do epitélio na derme, esta desorganização epitelial se deu principalmente nos estratos inferiores da epiderme e a estrutura da membrana basal foi afetada (VAUGHAN et al., 2009). A via de sinalização EGFR-Ras-Raf está relacionada com o processo de cicatrização de feridas e com o desenvolvimento do câncer, a diferença é que na cicatrização a via é autolimitada, enquanto que na carcinogênese é marcada por uma via constitutivamente ativada (DOMA; RUPP; BACCARINI, 2013). As alterações na integridade tecidual somada ao aumento da expressão deste gene no grupo sadio reforçam a hipótese que 15 dias após a TFD, o tecido está no processo de remodelamento e a via de sinalização que Ras participa pode estar colaborando com esse mecanismo, isto precisa ser mais investigado em futuras pesquisas.

Com relação ao gene p53, um fator de transcrição que codifica a proteína p53, presente geralmente no núcleo quando está ativa, pode regular várias funções biológicas, como por exemplo, o reparo, crescimento e apoptose (OLIVEIRA et al., 2007). Em nosso estudo, a maioria das amostras foi positiva à detecção nuclear de p53. A proteína normal tem meia vida curta e dificilmente é detectada na técnica de imuno-histoquímica (MEEK, 2009). Entretanto, mutações no gene p53 resultam na produção de uma proteína mais estável do que o tipo selvagem, com acúmulo intracelular da proteína p53 disfuncional e positiva à imunohistoquímica (BATINAC et al., 2006). Bukhari et al. (2009) avaliaram por PCR que 96,25\% dos pacientes do Paquistão com CEC apresentaram mutações no gene p53, a expressão da proteína detectada por imuno-histoquímica ocorreu em $85,7 \%$ dos casos avaliados, porém na pele de pessoas sadias p53 não foi detectado. No nosso estudo, a positividade de p53 foi alta, isso pode indicar que ocorreu alteração na expressão dessa proteína. Mutações ou perda na função de p53 tem papel importante no processo de carcinogênese, as células não param mais na fase G1 e sem reparo prosseguem no ciclo celular com danos no DNA estabelecidos e 
consequentemente ocorre expansão clonal destas células (BATINAC et al., 2006; OLIVEIRA et al., 2007).

Mesmo os animais sadios sem tratamento, mostraram marcação fraca de p53, assim como os animais dos grupos sadios tratados. Um dos principais achados relacionado à p53 no presente estudo foi sua marcação citoplasmática de forma difusa no estrato granuloso em todas as amostras avaliadas. Segundo Ren et al. (1996), o padrão de marcação de p53 avaliado por imuno-histoquímica pode ser distinguido de duas formas: quando a marcação é difusa, pode indicar que a proteína selvagem está superexpressa; o padrão de marcação mais compacto indica mutação no gene. Moll et al. (1995) verificaram que em neuroblastomas indiferenciados, independentes do estágio clínico, apresentaram o padrão citoplasmático em todas as marcações imuno-histoquímicas e que as sequências codificantes eram do tipo selvagem e o gene não estava alterado.

Em tecidos sadios, a presença de p53 no citoplasma está relacionada à sua degradação por meio do seu regulador negativo MDM2 por via de ubiquitinação, a proteína p53 também regula a expressão de MDM2. Quando os níveis de p53 estão altos na célula, MDM2 aumenta a expressão, por isso, p53 tem vida curta, pois é exportado do núcleo para o citoplasma onde é rapidamente degradado (O’BRATE; GIANNAKAKOU, 2003). Entretanto, o acúmulo de p53 do tipo selvagem no citoplasma de neuroblastomas indicou que a funcionalidade dessa proteína em alvos de p53 analisados não foi perdida, portanto, quando as células foram irradiadas, os alvos de p53 não estavam mais expressos, indicando que p53 citoplasmático pode estar envolvido com funções na célula não diretamente ligadas à sua degradação, mas sua expressão foi confirmada tantos nos neuroblastomas irradiados como nos controles, portanto, sem esclarecimento de uma função definida (GOLDMAN et al., 1996). A superexpressão de p53 citoplasmático foi relatado em carcinoma oral (PUKKILA et al., 2002), em câncer colorretal (FLAMINI et al., 1996), no CEC cutâneo (BUKHARI et al. 2009; RHIM et al., 1995) e esta relacionada ao pior prognóstico da doença. Se o gene estiver mutado, a perda de p53 ou sua inativação pode não induzir as células à apoptose, conferindo resistência ao tratamento.

No grupo CEC tratado, no período de 24 horas após TFD e nos animais sadios tratados nos dois períodos, a expressão gênica de p53 diminuiu significativamente. Bukhari et al. (2009) avaliaram a expressão de p53 e AgNOR mediante ao tratamento com retinol em camundongos que foram expostos aos carcinógenos DMBA/TPA; a expressão desses marcadores foi alta em lesões classificadas como malignas e não ocorreu resposta ao tratamento. Na presente pesquisa, a diminuição da expressão gênica de p53 no grupo CEC 
tratado pode estar relacionada com os baixos índices de apoptose encontrados nesses tecidos. Entretanto, no grupo sadio tratado no período de 15 dias, a expressão deste gene pode estar relacionada às respostas aos danos sofridos após TFD.

As proteínas Bak e Bcl-xL são reguladores da apoptose, Bak atua na ativação da apoptose na células, ao passo que Bcl-xL apresenta uma função contrária à de Bak, pois inibe a apoptose. Essas proteínas contêm um segmento hidrofóbico que conferem a elas uma ancoragem em membranas (DUPREZ et al., 2009; YAN; SHI, 2005; YOULE; STRASSER, 2008). Neste trabalho, Bak e Bcl-xL apresentaram expressão citoplasmática no epitélio e ambas expressaram marcações no núcleo das células do sistema imune na derme. As marcações citoplasmáticas destas proteínas foram fracamente marcadas por imunohistoquímica na maioria dos grupos experimentais. O padrão de marcação citoplasmática de Bak no epitélio está de acordo com os achados na literatura (SHABNAMA et al., 2004; UDAYANGA et al., 2011). No presente trabalho, a marcação tanto de Bak como de Bcl-xL relatada nas células do sistema imune ocorreu em neutrófilos e linfócitos. Shabnama et al. (2004) apresentou uma descrição de linfócitos encontrados no estroma do carcinoma de células escamosas do pulmão que foram fracamente marcados por estas proteínas. Esses tipos celulares possuem vida curta no tecido, isso deve explicar a detecção dessas proteínas reguladoras da apoptose nesses tipos celulares.

A expressão gênica de Bak foi maior no grupo sadio tratado após 15 dias da TFD quando comparado ao controle. Esses dados corroboram com a pesquisa de Lai et al. (2001) na qual, a expressão de Bak foi intensificada após a TFD utilizando derivado de hematoporfirina (PSD007) como FS na pele de pacientes com carcinoma de nasofaringe. $\mathrm{O}$ aumento na expressão gênica de Bak pode estar relacionado com o aumento da marcação de caspase 3 clivada observada neste grupo, indicando a ocorrência de um processo apoptótico nesse tecido.

Assim como a marcação imuno-histoquímica foi fraca para Bcl-xL, a expressão deste gene foi baixa na maioria dos grupos experimentais, portanto, significativamente diminuída no grupo CEC tratado após 24 horas da TFD. A desregulação dos membros antiapoptoticos da família Bcl-2 é uma característica comum nas neoplasias em humanos e causam resistência à terapia nessas doenças (SANTOS; CARVALHO, 2011). A baixa expressão deste gene no grupo CEC tratado pode estar relacionada com a baixa expressão dos marcadores apoptóticos, indicando que a TFD-AM na dosagem que foi utilizada não provocou morte direta nas células tumorais. 
Dentre os efeitos após tratamento pela TFD nos grupos induzidos ao CEC destacam-se a redução tumoral, diminuição no índice do PCNA e diminuição na expressão de genes relacionados ao desenvolvimento do CEC, H-ras e p53 24 horas após tratamento indicando que a TFD influencia na modulação destes marcadores de forma aguda, isto confere um bom prognóstico no tratamento desta neoplasia. Por outro lado, a remissão total dos tumores não ocorreu e foram poucas as alterações morfológicas teciduais após tratamento devido à baixa dose de energia total aplicada e única sessão da TFD conforme proposto neste trabalho. Os mecanismos de ação da TFD não foram eficientes em causar morte celular direta por apoptose ou necrose; ativação efetiva do sistema imune e destruição da vascularização do tumor. Os resultados obtidos na pele sadia indicaram que ocorreu morte celular por apoptose pelo aumento no índice de células marcadas pela caspase 3 clivada, na expressão gênica de Bak e nos níveis da citocina TNF- $\alpha$. Os resultados no grupo sadio ainda sugerem que o tecido está em processo de remodelação no período de 15 dias após tratamento, principalmente pela presença de fibroblastos reativos e aumento no número de vasos. O presente trabalho contribuiu com a avaliação de várias respostas teciduais relacionadas ao tratamento em modelo experimental in vivo com única aplicação da TFD, entretanto, estudos mais aprofundados são de extrema importância para estabelecer os mecanismos moleculares envolvidos em várias vias de sinalização previamente indicadas nesta pesquisa. Podemos inferir que ajustes na aplicação da TFD mediada pelo AM e estudos em longo prazo são necessários, portanto, os resultados obtidos nesta pesquisa apresentaram boas perspectivas para ensaios clínicos futuros no tratamento do CEC e na área dermatológica. 


\section{CONCLUSÕES}

$\mathrm{Na}$ avaliação histopatológica do carcinoma espinocelular cutâneo e pele sadia de camundongos após terapia fotodinâmica mediada por azul de metileno, em dois períodos avaliados, 24 horas e 15 dias após o tratamento, conclui-se que:

1. O protocolo de carcinogênese utilizado nesta pesquisa foi efetivo na indução do CEC.

2. A TFD reduziu o tamanho dos tumores em diâmetro, 24 horas e 15 dias depois do tratamento.

3. A avaliação histopatológica indicou poucas alterações na morfologia dos tecidos tumorais tratados pela TFD, entretanto, os tecidos sadios tratados apresentaram áreas danificadas na derme após 24 horas do tratamento e depois de 15 dias do tratamento ocorreu aumento na espessura epitelial e a derme apresentou possível remodelamento tecidual pela presença de fibroblastos reativos e formação de novos vasos sanguíneos.

4. A TFD diminuiu a quantidade de colágeno tipo I nos grupos sadios tratados, nos dois períodos avaliados.

5. O tratamento pela TFD diminuiu o índice de proliferação celular epitelial, nos grupos induzido ao CEC e sadio no período de 15 dias após tratamento.

6. Na dosagem aplicada, o tratamento pela TFD não foi eficaz em provocar morte celular direta por apoptose ou necrose no tecido tumoral, portanto, nos grupos sadios tratados nos dois períodos avaliados ocorreu apoptose.

7. O tratamento pela TFD não resultou em ativação de linfócitos T CD8 nos dois períodos avaliados, tanto no tecido tumoral quanto no sadio. Portanto, a TFD melhorou o reconhecimento do sistema imune pelo aumento nas concentrações plasmáticas de IL-2 nos grupos CECs tratados nos dois períodos avaliados, aumento na concentração de IL-1 $\beta$ no grupo CEC tratado 15 dias após tratamento e aumento na concentração de TNF- $\alpha$ no grupo sadio tratado 15 dias depois da TFD. 
8. Ocorreu aumento no número de vasos no tecido sadio 15 dias depois da TFD.

9. A TFD nos grupos induzidos ao CEC diminuiu a expressão de genes envolvidos no desenvolvimento do CEC, p53 e H-ras após 24 horas do tratamento. Com relação aos tecidos sadios, p53 e H-ras atuam na regulação da apoptose e ciclo celular, respectivamente, a TFD diminuiu a expressão de p53 no grupo sadio 24 horas após tratamento e aumentou a expressão de H-ras 15 dias depois da TFD.

10. A TFD atuou nos mecanismos de regulação da apoptose pela diminuição na expressão gênica de um membro bloqueador da apoptose, Bcl-xL no grupo induzido ao CEC 24 horas após tratamento. A TFD teve efeito na estimulação da apoptose pelo aumento na expressão do gene Bak no grupo sadio 15 dias após tratamento.

11. O tratamento pela TFD mediado por AM não conferiu melhora no tratamento do CEC neste modelo experimental, pois a dose total de energia foi baixa associada à única sessão do tratamento. Resultados melhores foram obtidos nos grupos sadios tratados que indicaram que a TFD-AM, em única sessão e na dose utilizada foi eficaz em provocar morte celular por apoptose e há indícios de remodelação neste tecido. Embora, o tratamento não tenha causado morte das células tumorais, ajustes no número de sessões ou dose total de energia poderão melhorar a eficácia da TFD mediada por AM. 


\section{REFERÊNCIAS*}

ABEL, E. L. et al. Multi-stage chemical carcinogenesis in mouse skin: fundamentals and applications. Nat. Protoc., v. 4, n. 9, p. 1350-1362, 2009.

ACKROYD, R. et al. The history of photodetection and photodynamic therapy. Photochem. Photobiol., v. 74, n. 5, p. 656-669, 2001.

ALMEIDA, R. D. et al. Intracellular signaling mechanisms in photodynamic therapy. Biochim. Biophys. Acta, v. 1704, n. 2, p. 59-86, 2004.

ARIAS, G. A. M. et al. Photodynamic therapy. Med. Cutan. Iber. Lat. Am., v. 35, n. 6, p. 255-268, 2007.

ARMSTRONG, B. K.; KRICKER, A. The epidemiology of UV induced skin cancer. J. Photochem. Photobiol. B, v. 63, n. 1-3, p. 8-18, 2001.

BACHMANN, M. F.; OXENIUS, A. Interleukin 2: from immunostimulation to immunoregulation and back again. EMBO Rep., v. 8, n. 12, p. 1142-1148, 2007.

BAHNER, J. D.; BORDEAUX, J. S. Non-melanoma skin cancers: photodynamic therapy, cryotherapy, 5-fluorouracil, imiquimod, diclofenac, or what? Facts and controversies. Clin. Dermatol., v. 31, n. 6, p. 792-798, 2013.

BALMAIN, A.; HARRIS, C. C. Carcinogenesis in mouse and human cells: parallels and paradoxes. Carcinogenesis, v. 21, n. 3, p. 371-377, 2000.

BAPTISTA, J. et al. Our PDT experience in the treatment of non-melanoma skin cancer over the last 7 years. J. Eur. Acad. Dermatol. Venereol., v. 20, n. 6, p. 693-697, 2006.

BARCESSAT, A. R. et al. Effect of topical 5-ALA mediated photodynamic therapy on proliferation index of keratinocytes in 4-NQO-induced potentially malignant oral lesions. $\mathbf{J}$. Photochem. Photobiol. B, v. 126, p. 33-41, 2013.

BATINAC, T. et al. Expression of cell cycle and apoptosis regulatory proteins in keratoacanthoma and squamous cell carcinoma. Pathol. Res. Pract., v. 202, n. 8, p. 599-607, 2006.

BELICHA-VILLANUEVA, A. et al. The effect of photodynamic therapy on tumor cell expression of major histocompatibility complex (MHC) class I and MHC class I-related molecules. Lasers Surg. Med., v. 44, n. 1, p. 60-68, 2012.

BHUVANESWARI, R. et al. Molecular profiling of angiogenesis in hypericin mediated photodynamic therapy. Mol. Cancer, v. 7, n. 56, p. 1-14, 2008.

\footnotetext{
*De acordo com:

ASSOCIAÇÃO BRASILEIRA DE NORMAS TÉCNICAS. NBR 6023: informação e documentação: referências: elaboração. Rio de Janeiro, 2002.
} 
BOIY, A.; ROELANDTS, R.; DE WITTE, P. A. Photodynamic therapy using topically applied hypericin: comparative effect with methyl-aminolevulinic acid on UV induced skin tumours. J Photochem. Photobiol. B, v. 102, n. 2, p. 123-131, Feb 2011.

BOUKAMP, P. Non-melanoma skin cancer: what drives tumor development and progression? Carcinogenesis, v. 26, n. 10, p. 1657-1667, 2005.

BRODERS, A. C. SQUAMOUS-CELL EPITHELIOMA OF THE SKIN. ANNALS of SURGERY, v. LXXIII, n. 2, p. 141-160, 1921.

BROUGHAM, N. D. et al. The incidence of metastasis from cutaneous squamous cell carcinoma and the impact of its risk factors. J. Surg. Oncol., v. 106, n. 7, p. 811-815, 2012.

BUKHARI, M. H. et al. Elevated frequency of p53 genetic mutations and AgNOR values in squamous cell carcinoma. J. Cutan. Pathol., v. 36, n. 2, p. 220-228, 2009.

BUYTAERT, E.; DEWAELE, M.; AGOSTINIS, P. Molecular effectors of multiple cell death pathways initiated by photodynamic therapy. Biochim. Biophys. Acta, v. 1776, n. 1, p. 86107, 2007.

BYUN, J. Y. et al. Expression of IL-10, TGF-beta(1) and TNF-alpha in Cultured Keratinocytes (HaCaT Cells) after IPL Treatment or ALA-IPL Photodynamic Treatment. Ann. Dermatol., v. 21, n. 1, p. 12-17, 2009.

CALZAVARA-PINTON, P. G. et al. Methylaminolaevulinate-based photodynamic therapy of Bowen's disease and squamous cell carcinoma. Br. J. Dermatol., v. 159, n. 1, p. 137-144, 2008.

CASTANO, A. P.; DEMIDOVA, T. N.; HAMBLIN, M. R. Mechanisms in photodynamic therapy: part one-photosensitizers, photochemistry and cellular localization. Photodiagnosis and Photodynamic Therapy, v. 1, p. 279-293, 2004.

CASTANO, A. P.; DEMIDOVA, T. N.; HAMBLIN, M. R. Mechanisms in photodynamic therapy: Part three-Photosensitizer pharmacokinetics, biodistribution, tumor localization and modes of tumor destruction. Photodiagnosis and Photodynamic Therapy, v. 2, p. 91-106, 2005.

CASTANO, A. P.; MROZ, P.; HAMBLIN, M. R. Photodynamic therapy and anti-tumour immunity. Nature Reviews. v. 6, p. 535-545, 2006.

CECIC, I.; PARKINS, C. S.; KORBELIK, M. Induction of systemic neutrophil response in mice by photodynamic therapy of solid tumors. Photochem. Photobiol., v. 74, n. 5, p. $712-$ $720,2001$.

CHAUDHURI, D. et al. Targeting the immune system in cancer. Curr Pharm Biotechnol, v. 10, n. 2, p. 166-184, 2009.

CHEN, Y. et al. Apoptosis induced by methylene-blue-mediated photodynamic therapy in melanomas and the involvement of mitochondrial dysfunction revealed by proteomics. Cancer Sci., v. 99, n. 10, p. 2019-2027, 2008. 
CHOI, J. Y. et al. Molecular changes following topical photodynamic therapy using methyl aminolaevulinate in mouse skin. J. Dermatol. Sci., v. 58, n. 3, p. 198-203, 2010.

CLARKE, P. R.; ALLAN, L. A. Cell-cycle control in the face of damage-a matter of life or death. Trends Cell Biol., v. 19, n. 3, p. 89-98, 2009.

CLOSE, B. et al. Recommendations for euthanasia of experimental animals: Part 2. DGXT of the European Commission. Lab. Anim., v. 31, n. 1, p. 1-32, 1997.

CONTASSOT, E.; BEER, H. D.; FRENCH, L. E. Interleukin-1, inflammasomes, autoinflammation and the skin. Swiss Med. Wkly., v. 142, p. 1-10, 2012.

CORY, S.; ADAMS, J. M. The Bcl2 family: regulators of the cellular life-or-death switch. Nat. Rev. Cancer, v. 2, n. 9, p. 647-656, 2002.

CUELLO-CARRIÓN, F. D.; CIOCCA, D. R. Improved detection of apoptotic cells using a modified in situ TUNEL technique. J. Histochem. Cytochem., v. 47, n. 6, p. 837-839, 1999.

DE LAAT, A.; VAN DER LEUN, J. C.; DE GRUIJL, F. R. Carcinogenesis induced by UVA (365-nm) radiation: the dose-time dependence of tumor formation in hairless mice. Carcinogenesis, v. 18, n. 5, p. 1013-1020, 1997.

DE VREE, W. J. et al. Role of interleukin 1 and granulocyte colony-stimulating factor in photofrin-based photodynamic therapy of rat rhabdomyosarcoma tumors. Cancer Res., v. 57, n. 13, p. 2555-2558, 1997.

DIGIOVANNI, J. Multistage carcinogenesis in mouse skin. Pharmac. Ther., v. 54, p. 63$128,1992$.

DOMA, E.; RUPP, C.; BACCARINI, M. EGFR-Ras-Raf Signaling in Epidermal Stem Cells: Roles in Hair Follicle Development, Regeneration, Tissue Remodeling and Epidermal Cancers. Int. J. Mol. Sci., v. 14, p. 19361-19384, 2013.

NOWIS, D. et al. The influence of photodynamic therapy on the immune response. Photodiagnosis and Photodynamic Therapy, v. 2, p. 283-298, 2005.

SANTOS, L. V.; CARVALHO, A. L. Bcl-2 targeted-therapy for the treatment of head and neck squamous cell carcinoma. Recent Pat. Anticancer Drug Discov., v. 6, n. 1, p. 45-57, 2011.

DOUGHERTY, T. J.; GOMER, C. J.; HENDERSON, B. W. Photodynamic Therapy. Journal of the National Cancer Institute, v. 90, n. 12, p. 889-905, 1998.

DRANOFF, G. Cytokines in cancer pathogenesis and cancer therapy. Nat. Rev. Cancer, v. 4, n. 1, p. 11-22, 2004.

DUPREZ, L. et al. Major cell death pathways at a glance. Microbes Infect., v. 11, n. 13, p. 1050-1062, 2009. 
ERMERTCAN, A. T.; HELLINGS, P. W.; CINGI, C. Nonmelanoma skin cancer of the head and neck: nonsurgical treatment. Facial Plast. Surg. Clin. North Am., v. 20, n. 4, p. 445454, 2012.

EVANS, S. et al. Effect of photodynamic therapy on tumor necrosis factor production by murine macrophages. J. Natl. Cancer Inst., v. 82, n. 1, p. 34-39, 1990.

FANTINI, F. et al. Pathologic changes after photodynamic therapy for Basal cell carcinoma and Bowen disease: a histologic and immunohistochemical investigation. Arch. Dermatol., v. 144, n. 2, p. 186-194, 2008.

FERNÁNDEZ-MEDARDE, A.; SANTOS, E. Ras in cancer and developmental diseases. Genes Cancer, v. 2, n. 3, p. 344-358, 2011.

FERRARIO, A. et al. Antiangiogenic treatment enhances photodynamic therapy responsiveness in a mouse mammary carcinoma. Cancer. Res., v. 60, n. 15, p. 4066-4069, 2000 .

FINGAR, V. H. et al. The role of microvascular damage in photodynamic therapy: the effect of treatment on vessel constriction, permeability, and leukocyte adhesion. Cancer Res., v. 52, n. 18, p. 4914-4921, 1992.

FLAMINI, G. et al. Prognostic significance of cytoplasmic p53 overexpression in colorectal cancer. An immunohistochemical analysis. Eur. J. Cancer, v. 32, n. 5, p. 802-806, 1996.

FUNGALOI, P. et al. Platelet adhesion to photodynamic therapy-treated extracellular matrix proteins. Photochem. Photobiol., v. 75, n. 4, p. 412-417, 2002.

GABRIEL, J. (ed). The biology of cancer. 2 ed. England: John Wiley \& Sons Ltd, 2007. 204 p.

GARCIA, V. G. et al. Effect of photodynamic therapy on the healing of cutaneous thirddegree-burn: histological study in rats. Lasers Med. Sci., v. 25, n. 2, p. 221-228, 2010.

GARCIA-ZUAZAGA, J.; OLBRICHT, S. M. Cutaneous squamous cell carcinoma. Adv. Dermatol., v. 24, p. 33-57, 2008.

GILLS, J. J. et al. Sulforaphane prevents mouse skin tumorigenesis during the stage of promotion. Cancer Lett., v. 236, n. 1, p. 72-79, 2006.

GOLDMAN, S. C. et al. The p53 signal transduction pathway is intact in human neuroblastoma despite cytoplasmic localization. Am. J. Pathol., v. 148, n. 5, p. 1381-1385, 1996.

GOLLNICK, S. O. et al. Role of cytokines in photodynamic therapy-induced local and systemic inflammation. Br. J. Cancer, v. 88, n. 11, p. 1772-1779, 2003.

GOLLNICK, S. O.; OWCZARCZAK, B.; MAIER, P. Photodynamic therapy and anti-tumor immunity. Lasers Surg. Med., v. 38, n. 5, p. 509-515, 2006. 
GUVEN-MAIOROV, E. et al. Structural pathways of cytokines may illuminate their roles in regulation of cancer development and immunotherapy. Cancers (Basel), v. 6, n. 2, p. 663683, 2014.

JACKSON, S. et al. Role of Bak in UV-induced apoptosis in skin cancer and abrogation by HPV E6 proteins. Genes Dev., v. 14, n. 23, p. 3065-3073, 2000.

JUARRANZ, Á. et al. Photodynamic therapy of cancer. Basic principles and applications. Clin Transl. Oncol. v.10, p. 148-154, 2008.

KASTAN, M. B.; BARTEK, J. Cell-cycle checkpoints and cancer. Nature, v. 432, n. 7015, p. 316-323, 2004.

KAUR, G.; ATHAR, M.; ALAM, M. S. Eugenol precludes cutaneous chemical carcinogenesis in mouse by preventing oxidative stress and inflammation and by inducing apoptosis. Mol. Carcinog., v. 49, n. 3, p. 290-301, 2010.

KAWCZYK-KRUPKA, A. et al. The role of photosensitized macrophages in photodynamic therapy. Oncol. Rep., v. 26, n. 1, p. 275-280, 2011.

KESSEL, D. Photodynamic therapy: from the beginning. Photodiagnosis and Photodynamic Therapy, v. 1, p. 3-7, 2004.

KHAVARI, P. A. Modelling cancer in human skin tissue. Nat. Rev. Cancer, v. 6, n. 4, p. 270-280, 2006.

KIM, S. K.; KIM, E. H.; KIM, Y. C. Treatment of pigmented purpuric dermatosis with topical photodynamic therapy. Dermatology, v. 219, n. 2, p. 184-186, 2009.

KORBELIK, M.; DOUGHERTY, G. J. Photodynamic therapy-mediated immune response against subcutaneous mouse tumors. Cancer Res., v. 59, n. 8, p. 1941-1946, 1999.

KORBELIK, M. et al. The role of inflammatory cytokines in the response of solid cancers to photodynamic therapy. Proceedings of SPIE, v. 4248, p. 107-113, 2001.

KRYSKO, D. V. et al. Methods for distinguishing apoptotic from necrotic cells and measuring their clearance. Methods Enzymol, v. 442, p. 307-341, 2008.

KUBLER, A. C. Photodynamic therapy. Medical Laser Application, v. 20, p. 37-45, 2005.

KYRIAZI, M. et al. Topical photodynamic therapy of murine non-melanoma skin carcinomas with aluminum phthalocyanine chloride and a diode laser: pharmacokinetics, tumor response and cosmetic outcomes. Photodermatol. Photoimmunol. Photomed., v. 24, n. 2, p. 87-94, 2008 .

LAI, J. et al. Effect of photodynamic therapy (PDT) on the expression of pro-apoptotic protein Bak in nasopharyngeal carcinoma (NPC). Lasers Surg. Med., v. 29, n. 1, p. 27-32, 2001. 
LeBOIT, P. E. Who Health Organization Classification of Tumours. Pathology and genetics of skin tumours. Lyon: IARC Press, 2006. 357 p.

LIVAK, K. J.; SCHMITTGEN, T. D. Analysis of relative gene expression data using real time quantitative PCR and the 2(-Delta Delta C(T)) Method. Methods, v. 25, n. 4, p. 402408, 2001.

LU, Y. et al. Methylene blue-mediated photodynamic therapy induces mitochondriadependent apoptosis in HeLa cell. J. Cell. Biochem., v. 105, n. 6, p. 1451-1460, 2008.

MAAS, A. L. et al. Tumor vascular microenvironment determines responsiveness to photodynamic therapy. Cancer Res., v. 72, n. 8, p. 2079-2088, 2012.

MACHADO, A. E. H. Terapia fotodinâmica: princípios, potencial de Aplicação e perspectivas. Química Nova. v. 23, n. 2, p. 237-243, 2000.

MAGA, G.; HUBSCHER, U. Proliferating cell nuclear antigen (PCNA): a dancer with many partners. J. Cell Sci., v. 116, n. 15, p. 3051-3060, 2003.

MANG, T. S. Lasers and light sources for PDT: past, present and future. Photodiagnosis and Photodynamic Therapy, v. 1, p. 43-48, 2004.

MARINO, J. et al. Lysosomal and mitochondrial permeabilization mediates zinc(II) cationic phthalocyanine phototoxicity. Int. J. Biochem. Cell Biol., v. 45, n. 11, p. 2553-2562, 2013.

MCKAY, I. A.; LEIGH, I. M. Epidermal cytokines and their roles in cutaneous wound healing. Br. J. Dermatol., v. 124, n. 6, p. 513-518, 1991.

MEEK, D. W. Tumour suppression by p53: a role for the DNA damage response? Nat. Rev. Cancer, v. 9, n. 10, p. 714-723, 2009.

MENEZES, P. F. C. et al. Photodynamic Activity of Different Dyes. Laser Physics., v. 17, n. 4, p. 468-471, 2007.

MICHOR, F.; IWASA, Y.; NOWAK, M. A. Dynamics of cancer progression. Nat. Rev. Cancer, v. 4, n. 3, p. 197-205, 2004.

MOLDOVAN, G. L.; PFANDER, B.; JENTSCH, S. PCNA, the maestro of the replication fork. Cell, v. 129, n. 4, p. 665-679, 2007.

MOLL, U. M. et al. Wild-type p53 protein undergoes cytoplasmic sequestration in undifferentiated neuroblastomas but not in differentiated tumors. Proc. Natl. Acad. Sci. U S A., v. 92, n. 10, p. 4407-4411, 1995.

MONTES, G. S.; JUNQUEIRA, L. C. The use of the Picrosirius-polarization method for the study of the biopathology of collagen. Mem. Inst. Oswaldo Cruz, v. 86, Suppl. 3, p. 1-11, 1991.

MOON, Y. H. et al. Efficient preparation of highly pure chlorin e6 and its photodynamic anticancer activity in a rat tumor model. Oncol. Rep., v. 22, n. 5, p. 1085-1091, 2009. 
MROZ, P. et al. Cell Death Pathways in Photodynamic Therapy of Cancer. Cancers, v. 3, p. 2516-2539, 2011.

INSTITUTO NACIONAL DO CÂNCER (INCA). JOSÉ ALENCAR GOMES DA SILVA, C. D. P. E. V. (ed) Estimativa 2014: Incidência de Câncer no Brasil. Rio de Janeiro: 2014. $124 \mathrm{p}$.

NARAYANAN, D. L.; SALADI, R. N.; FOX, J. L. Ultraviolet radiation and skin cancer. Int. J. Dermatol., v. 49, n. 9, p. 978-986, 2010.

NOWIS, D. et al. Direct tumor damage mechanisms of photodynamic therapy. Acta Biochim. Pol., v. 52, n. 2, p. 339-352, 2005.

O'BRATE, A.; GIANNAKAKOU, P. The importance of p53 location: nuclear or cytoplasmic zip code? Drug Resist. Updat., v. 6, n. 6, p. 313-322, 2003.

OLIVEIRA, P. A. et al. Chemical carcinogenesis. An. Acad. Bras. Cienc., v. 79, n. 4, p. 593616,2007

ORMOND, A. B.; FREEMAN, H. S. Dye Sensitizers for Photodynamic Therapy. Materials, v. 6, p. 817-840, 2013.

ORRINGER, J. S. et al. Molecular effects of photodynamic therapy for photoaging. Arch. Dermatol., v. 144, n. 10, p. 1296-1302, 2008.

ORTH, K. et al. Methylene blue mediated photodynamic therapy in experimental colorectal tumors in mice. J. Photochem. Photobiol. B, v. 57, n. 2-3, p. 186-192, 2000.

PELOI, L. S. et al. Photodynamic effect of light-emitting diode light on cell growth inhibition induced by methylene blue. J. Biosci., v. 33, n. 2, p. 231-237, 2008.

POIRIER, M. C. Chemical-induced DNA damage and human cancer risk. Discov. Med., v. 14, n. 77, p. 283-288, 2012.

POLAGER, S.; GINSBERG, D. p53 and E2f: partners in life and death. Nat. Rev. Cancer, v. 9, n. 10, p. 738-748, 2009.

PUKKILA, M. J. et al. Nuclear and cytoplasmic p53 expression in pharyngeal squamous cell carcinoma: prognostic implications. Head Neck, v. 24, n. 8, p. 784-791, 2002.

REN, Z. P. et al. Two distinct p53 immunohistochemical patterns in human squamous-cell skin cancer, precursors and normal epidermis. Int. J. Cancer, v. 69, n. 3, p. 174-179, 1996.

RENZI, C. et al. Factors associated with large cutaneous squamous cell carcinomas. J. Am. Acad. Dermatol., v. 63, n. 3, p. 404-411, 2010.

RHIM, K. J. et al. Over-expression of p53 protein in squamous cell carcinoma of the skin. J. Korean Med. Sci., v. 10, n. 1, p. 36-41, 1995. 
ROBERTSON, C. A.; EVANS, D. H.; ABRAHAMSE, H. Photodynamic therapy (PDT): A short review on cellular mechanisms and cancer research applications for PDT. Journal of Photochemistry and Photobiology B: Biology, v. 96, p. 1-8, 2009.

SCHMITT, E.; BEAUCHEMIN, M.; BERTRAND, R. Nuclear colocalization and interaction between bcl-xL and cdk1(cdc2) during G2/M cell-cycle checkpoint. Oncogene, v. 26, n. 40, p. 5851-5865, 2007.

SEVERINO, D. et al. Influence of negatively charged interfaces on the ground and excited state properties of methylene blue. Photochem. Photobiol., v. 77, n. 5, p. 459-468, 2003.

SHABNAM, M. S. et al. Expression of p53 protein and the apoptotic regulatory molecules Bcl-2, Bcl-XL, and Bax in locally advanced squamous cell carcinoma of the lung. Lung Cancer, v. 45, n. 2, p. 181-188, 2004.

SLAGA, T. J. SENCAR mouse skin tumorigenesis model versus other strains and stocks of mice. Environ. Health Perspect., v. 68, p. 27-32, Sep 1986.

SONG, D. et al. Photodynamic therapy using methylene blue to treat cutaneous leishmaniasis. Photomed. Laser Surg., v. 29, n. 10, p. 711-715, 2011.

SPERANDIO, F. F. et al. Photodynamic therapy mediated by methylene blue dye in wound healing. Photomed. Laser Surg., v. 28, n. 5, p. 581-587, 2010.

STRZALKA, W.; ZIEMIENOWICZ, A. Proliferating cell nuclear antigen (PCNA): a key factor in DNA replication and cell cycle regulation. Ann. Bot., v. 107, n. 7, p. 1127-1140, 2011.

STÄHELIN, B. J. et al. False positive staining in the TUNEL assay to detect apoptosis in liver and intestine is caused by endogenous nucleases and inhibited by diethyl pyrocarbonate. Mol. Pathol., v. 51, n. 4, p. 204-208, 1998.

SUN, J. et al. Neutrophils as inflammatory and immune effectors in photodynamic therapytreated mouse SCCVII tumours. Photochem. Photobiol. Sci., v. 1, n. 9, p. 690-695, 2002.

SUVARNA, K.; LAYTON, C.; BANCROFT, J. D. Bancroft's Theory and Practice of Histological Techniques. 7 ed. Edinburgh: 2012, 637 p.

SUÁREZ, B. et al. Occupation and skin cancer: the results of the HELIOS-I multicenter casecontrol study. BMC Public Health, v. 7, n. 180, p. 1-11, 2007.

SZEIMIES, R. M. et al. Clinical, histopathological and immunohistochemical assessment of human skin field cancerization before and after photodynamic therapy. Br. J. Dermatol., v. 167, n. 1, p. 150-159, 2012.

TAKAHASHI, H. et al. ATX-S10(Na)-photodynamic therapy inhibits cytokine secretion and proliferation of lymphocytes. J. Dermatol. Sci., v. 49, n. 2, p. 174-177, 2008.

TARDIVO, J. P. et al. New photodynamic therapy protocol to treat AIDS-related Kaposi's sarcoma. Photomed. Laser Surg., v. 24, n. 4, p. 528-531, 2006. 
TARDIVO, J. P. et al. Methylene blue in photodynamic therapy: From basic mechanisms to clinical applications. Photodiagnosis and Photodynamic Therapy, v. 2, p. 175-191, 2005.

TOLEDO, F.; WAHL, G. M. Regulating the p53 pathway: in vitro hypotheses, in vivo veritas. Nat. Ver. Cancer, v. 6, n. 12, p. 909-923, 2006.

TOlOSA, E. M. C.; RODRIGUES, C. J.; BEHMER, O. A. Manual de técnicas para histologia normal e patológica. São Paulo: Editora Manole, 2005. 341p.

UDAYANGA, K. G. et al. Immunohistochemical study of the apoptosis process in epidermal epithelial cells of rats under a physiological condition. Histol. Histopathol., v. 26, n. 7, p. 811-820, 2011.

VASILJEVIĆ, N. et al. The Bcl-xL inhibitor of apoptosis is preferentially expressed in cutaneous squamous cell carcinoma compared with that in keratoacanthoma. Int. J. Cancer, v. 124, n. 10, p. 2361-2366, 2009.

VAUGHAN, M. B. et al. H-ras expression in immortalized keratinocytes produces an invasive epithelium in cultured skin equivalents. PLoS One, v. 4, n. 11, p. e7908, 2009.

WAGNER, M. et al. Methylene blue photodynamic therapy in malignant melanoma decreases expression of proliferating cell nuclear antigen and heparanases. Clin. Exp. Dermatol., v. 37, n. 5, p. 527-533, Jul 2012.

WAINWRIGHT, M. The development of phenothiazinium photosensitisers. Photodiagnosis and Photodynamic Therapy, v. 2, p. 263-272, 2005.

WANG, $\mathrm{H}$. et al. Therapeutic and immune effects of 5-aminolevulinic acid photodynamic therapy on UVB-induced squamous cell carcinomas in hairless mice. Exp. Dermatol., v. 22, n. 5, p. 362-363, 2013.

WILSON, J. A.; EVANS, A. T. Pathology of malignant tumours of the skin. Surgery, v. 28, n. 10, p. 473-477, 2010.

XUE, L. Y. et al. Photodamage to multiple Bcl-xL isoforms by photodynamic therapy with the phthalocyanine photosensitizer Pc 4. Oncogene, v. 22, n. 58, p. 9197-9204, 2003.

YAN, N.; SHI, Y. Mechanisms of apoptosis through structural biology. Annu. Rev. Cell Dev. Biol., v. 21, p. 35-56, 2005.

YOM, S. S. et al. Elevated serum cytokine levels in mesothelioma patients who have undergone pleurectomy or extrapleural pneumonectomy and adjuvant intraoperative photodynamic therapy. Photochem. Photobiol., v. 78, n. 1, p. 75-81, 2003.

YOULE, R. J.; STRASSER, A. The BCL-2 protein family: opposing activities that mediate cell death. Nat. Rev. Mol. Cell Biol., v. 9, n. 1, p. 47-59, 2008.

ZHANG, J.; BOWDEN, G. T. Targeting Bcl-X(L) for prevention and therapy of skin cancer. Mol. Carcinog., v. 46, n. 8, p. 665-670, 2007. 